Universidade de São Paulo

Instituto de Psicologia

Departamento de Psicologia Clínica

SARAH IZBICKI

ACEITAÇÃO E REJEIÇÃO DE ALUNOS POR SEUS PROFESSORES EM DIFERENTES NÍVEIS ESCOLARES

São Paulo

2015 
SARAH IZBICKI

Versão revisada

\title{
ACEITAÇÃO E REJEIÇÃO DE ALUNOS POR SEUS PROFESSORES EM DIFERENTES NÍVEIS ESCOLARES
}

\begin{abstract}
Dissertação apresentada ao Instituto de Psicologia da Universidade de São Paulo, como parte dos requisitos para obtenção do grau de Mestre em Psicologia.
\end{abstract}

Área de Concentração: Psicologia Clínica

Orientadora: Profaㅡ Drā Márcia H. S. Melo Bertolla

São Paulo

2015 
AUTORIZO A REPRODUÇÃO E DIVULGAÇÃO TOTAL E PARCIAL DESTE TRABALHO, POR QUALQUER MEIO CONVENCIONAL OU ELETRÔNICO, PARA FINS DE ESTUDO E PESQUISA, DESDE QUE CITADA A FONTE.

Catalogação na publicação

Biblioteca Dante Moreira Leite

Instituto de Psicologia da Universidade de São Paulo

Izbicki, Sarah.

Aceitação e rejeição de alunos por seus professores em diferentes níveis escolares / Sarah Izbicki; orientadora Márcia Helena da Silva Melo. -- São Paulo, 2015.

$148 \mathrm{f}$.

Dissertação (Mestrado - Programa de Pós-Graduação em Psicologia. Área de Concentração: Psicologia Clínica) - Instituto de Psicologia da Universidade de São Paulo.

1. Interação professor-aluno 2. Aceitação social 3. Rejeição social 4. Ensino fundamental 5. Ensino médio I. Título. 
Título: Aceitação e rejeição de alunos por seus professores em diferentes níveis escolares

Dissertação apresentada ao Instituto de Psicologia da Universidade de São Paulo para obtenção do título de Mestre em Psicologia Clínica

Aprovado em:

BANCA EXAMINADORA

Prof ${ }^{\text {a }}$ Dr ${ }^{\text {a }}$ Márcia Helena da Silva Melo Bertolla

Universidade São Paulo

Prof $^{\mathrm{a}} \mathrm{Dr}^{\mathrm{a}}{ }^{\mathrm{a}}$ Maria Cristina Triguero Veloz Teixeira

Universidade Presbiteriana Mackenzie

Prof $^{\text {a }} \operatorname{Dr}^{\text {a }}$ Olga Mitsue Kubo

Universidade Federal de Santa Catarina 


\section{Agradecimentos}

Aos meus pais Meyer e Deborah, por absolutamente tudo o que fizeram e fazem por mim: incentivo, apoio, amor, carinho, dedicação, paciência, ensinamentos, sugestões, inspirações, consolos, conversas, valores...

À Márcia Melo, por sempre dar o seu melhor como professora, supervisora e orientadora, por me acolher nos momentos de dificuldade e por me mostrar que tudo é possível.

Ao meu irmão Rafael, por ser meu maior modelo, sempre me ensinando a querer ir cada vez mais longe.

Ao meu noivo Rodolfo, pela companhia na profissão e na vida, nos momentos de felicidade e de crise.

Aos meus avós Leon e Ita, por sempre se preocuparem com minha felicidade e por me mostrarem o que é perseverança.

À minha avó Rebecca, que se faz presente em meus pensamentos, sempre me lembrando do quanto torcia por mim.

Ao Prof. Dr. Rafael Izbicki, pelas contribuições essenciais com as análises estatísticas.

Aos meus colegas do grupo de pesquisa, Felipe, Luan, Luiza, Mariana e Renata, pelos momentos de apoio e pelas produtivas discussões.

Aos professores que participaram do estudo e às escolas que abriram suas portas para que a pesquisa fosse possível.

À Fundação de Amparo à Pesquisa do Estado de São Paulo (FAPESP), pela concessão da bolsa de estudos. 
"Sophie had never thought about it before. But the more she did, the more clearly she saw that knowing what you don't know is also a kind of knowledge." (Sophie's World) 


\section{RESUMO}

Izbicki, Sarah. (2015). Aceitação e rejeição de alunos por seus professores em diferentes níveis escolares. Dissertação de Mestrado, Instituto de Psicologia, Universidade de São Paulo, São Paulo.

Percepções, expectativas e preferências dos professores variam em função de diversos fatores (características do aluno, currículo escolar, regras da escola etc.) e são expressas através de diferentes atitudes diante dos alunos, de modo a exercerem considerável influência no repertório comportamental dessas crianças e adolescentes. Considerando (a) a importância de uma relação positiva entre professor e aluno no decorrer da vida escolar do estudante, (b) as mudanças que ocorrem nesse relacionamento ao longo dos anos, e (c) que mesmo mudanças pequenas na qualidade dessa relação apresentam implicações relevantes para o desenvolvimento do aluno, necessita-se examinar quais fatores se associam a essas modificações. O objetivo geral da pesquisa foi explicitar as variáveis controladoras da rejeição e da aceitação de alunos, relatadas por seus professores, avaliando-se possíveis diferenças entre três níveis distintos de ensino. Especificamente, o estudo visou a (1) comparar as frequências com que os alunos de cada sexo são indicados como aceitos ou como rejeitados pelos professores nos três níveis, (2) comparar as razões alegadas pelos professores ao indicarem os alunos como aceitos ou como rejeitados nos três níveis e (3) identificar possíveis associações entre as razões para aceitação e para rejeição e o sexo dos alunos indicados. Vinte e um professores de $1^{\circ}$ ano do Ensino Fundamental I, 16 do $6^{\circ}$ ano do Ensino Fundamental II e 28 do $1^{\circ}$ ano do Ensino Médio preencheram questionário em que indicaram três alunos que manteriam em sua classe e três que não manteriam, explicitando as razões para tais indicações. Análises inferenciais não apresentaram diferenças entre os sexos dos alunos aceitos e houve pouca associação entre as razões para aceitação e rejeição e o sexo dos alunos. Por outro lado, encontraram-se diferenças nos sexos dos alunos rejeitados nos três anos estudados, com uma proporção maior de meninos rejeitados. Também foram encontradas diferenças nas razões mencionadas para aceitação, havendo um aumento de citações de engajamento nos estudos e redução de citações de disciplina ao longo dos níveis. Por fim, encontraram-se diferenças nas razões citadas para rejeição, com um aumento de citações de falta de engajamento nos estudos e redução de menções de indisciplina. Os resultados sugerem padrões diferenciados de aceitação e rejeição ao longo dos níveis escolares estudados, os quais podem ser utilizados no delineamento de intervenções que tenham por objetivo lidar de modo mais eficiente com os comportamentos dos envolvidos, estabelecendo relacionamentos mais reforçadores para alunos e professores e repertórios socialmente habilidosos nos estudantes.

Palavras-chave: Interação professor-aluno; Aceitação social; Rejeição social; Ensino Fundamental; Ensino Médio 


\begin{abstract}
Izbicki, Sarah. (2015). Acceptance and rejection of students by their teachers at different grade levels. Dissertação de Mestrado, Instituto de Psicologia, Universidade de São Paulo, São Paulo.
\end{abstract}

Perceptions, expectations and preferences of teachers differ according to several variables (students' characteristics, school curriculum, schools' rules etc.) and are expressed by them through different attitudes taken before the students, so that they considerably influence those youngsters' behavioral repertoire. Given (a) the importance of a positive relationship between teacher and student in the course of student's school life, (b) the changes which occur in this relationship over the years, and (c) that even minor changes in the quality of this relationship have relevant implications for the student's development, it is necessary to investigate which factors are associated with those changes. The general aim of this research is to reveal the controlling variables of rejection and acceptance of students, as reported by their teachers, assessing potential differences between three different grade levels. Specifically, the study aimed to (1) compare the frequencies in which the students of each gender are indicated as accepted or rejected by their teachers at the three levels, (2) compare the reasons reported by the teachers to indicate the students as accepted or rejected at the three levels and (3) identify possible associations between the reasons for acceptance and rejection and the gender of the indicated students. 21 teachers of first grade of elementary school, 16 of sixth year of middle school and 28 of ninth grade of high school completed a questionnaire in which they indicated three students they would keep in their class and three students they would not, explaining the reasons for the indications. Inferential analyses did not show differences between the gender of the accepted students, and revealed small associations between the reasons for acceptance and rejection and the sex of the student. Nonetheless, there were differences between the genders of the rejected students, where a higher proportion of rejected boys was found. There were also differences between reasons for acceptance along the different educational levels, where there was an increase in the number of citations to engagement in studies and a reduction in the number of citations to discipline. Finally, we found differences in the reasons for rejection, with an increase in the number of citations to the lack of engagement in the studies, and a reduction in the number of citations to the indiscipline. The results suggest different patterns of acceptances and rejection along the different educational levels, which can be used to delineate interventions that aim to deal effectively with the behavior of the people involved, creating more reforcing interactions for students and teachers and socially skilled repertoires in students.

Keywords: Teacher-student interaction; Social acceptance; Social rejection; Elementary education; Secondary school 
O presente trabalho foi realizado com o apoio financeiro da Fundação de Amparo à Pesquisa do Estado de São Paulo. 


\section{Sumário}

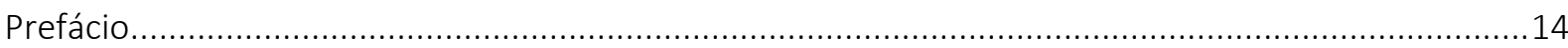

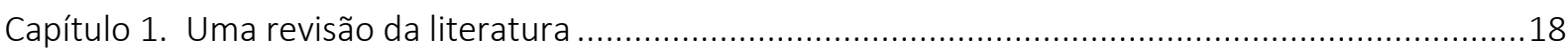

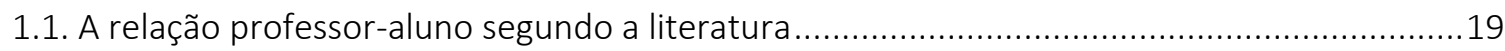

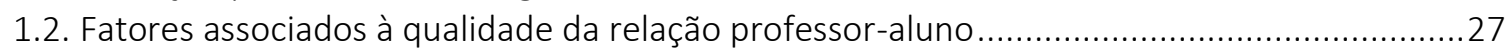

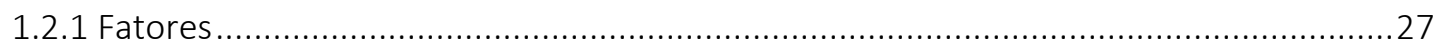

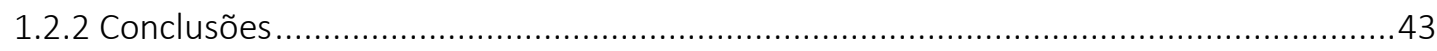

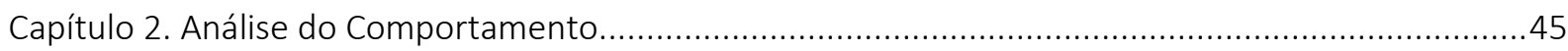

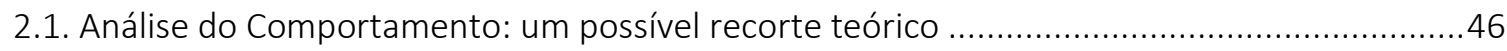

2.2. A relação professor-aluno sob a ótica da Análise do Comportamento ..................................49

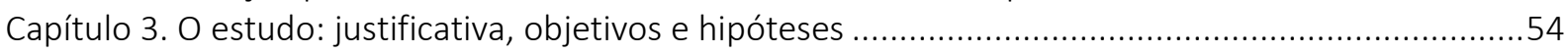

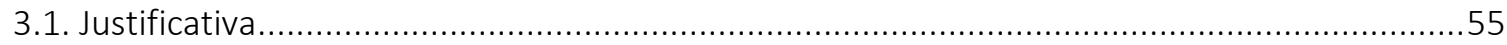

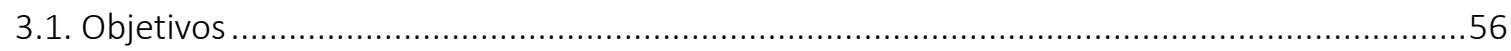

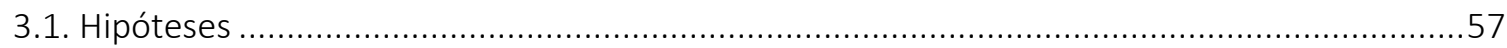

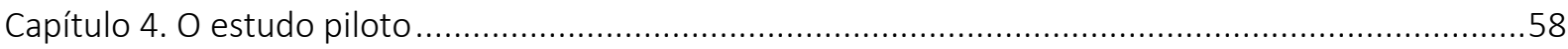

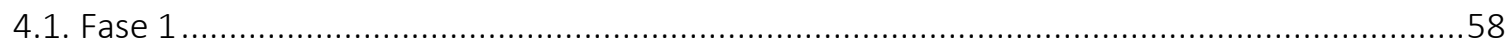

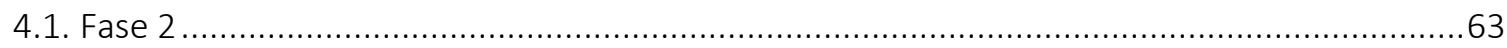

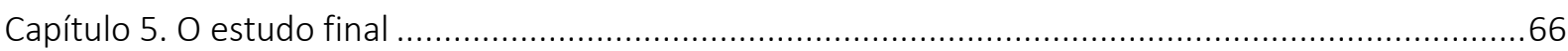

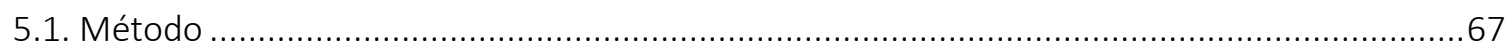

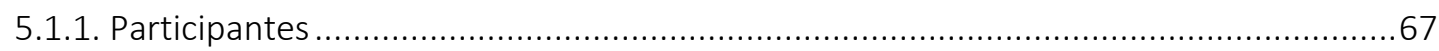

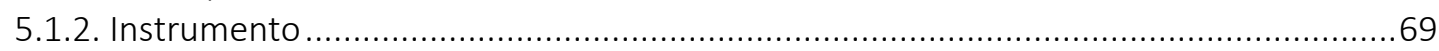

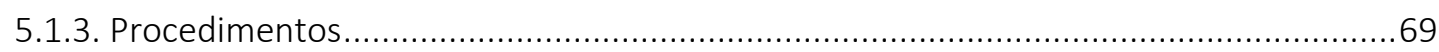

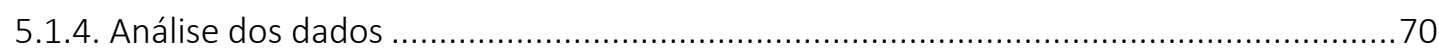

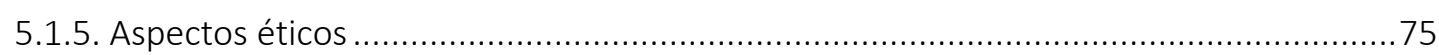

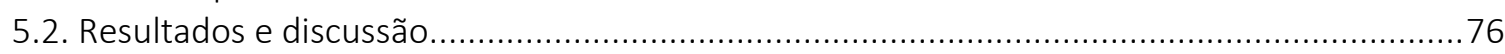

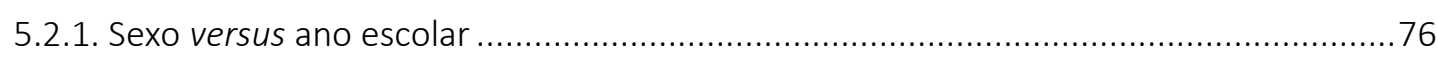

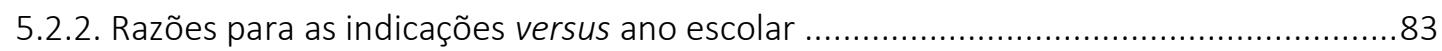

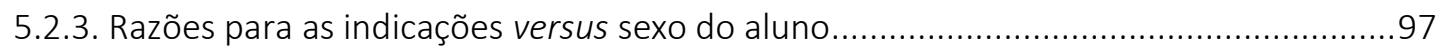

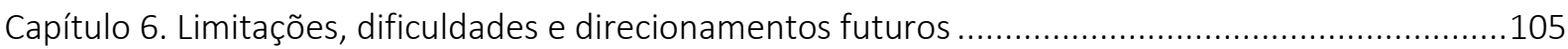

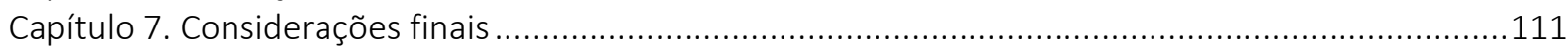

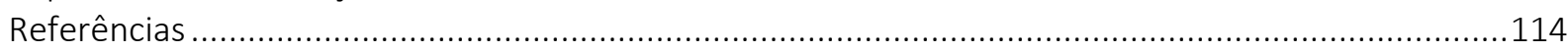




\section{Lista de Figuras}

Figura 1. Explicitação esquemática de componentes constituintes do comportamento "ensinar" para exemplificar como esses componentes constituem a relação (entre situação antecedente a uma classe de respostas, a própria classe de respostas e a situação consequente a essa classe de respostas)...... 49

Figura 2. Resultado das tentativas de obtenção de anuência das escolas para participação do estudo piloto da pesquisa......

Figura 3. Caracterização da amostra 68

Figura 4. Primeira versão das categorias de aceitação e rejeição.

Figura 5. Categorias de aceitação e de rejeição, elaboradas com base no agrupamento das razões alegadas pelos professores para a indicação de cada aluno

Figura 6. Proporções, em relação ao total de estudantes aceitos ou rejeitados em cada ano, de indicações de alunas e alunos nos três níveis escolares.....

Figura 7. Proporções de indicações de meninas e meninos aceitos feitas pelos professores de cada sexo

Figura 8. Proporções de indicações de meninas e meninos rejeitados feitas pelos professores de cada sexo.

Figura 9. Proporções de indicações de meninas e meninos aceitos feitas pelos professores que lecionam em cada área

Figura 10. Proporções de indicações de meninas e meninos rejeitados feitas pelos professores que lecionam em cada área.

Figura 11. Proporções totais de citações de cada categoria de aceitação, contabilizadas independentemente de sua menção isolada ou em conjunto com outras categorias, relativas ao total de citações em cada ano

Figura 12. Proporções de citações das categorias de aceitação, citadas isoladamente ou em conjunto com outras, relativas ao total de citações das categorias em cada ano.

Figura 13. Proporções totais de citações de cada categoria de rejeição, contabilizadas independentemente de sua menção isolada ou em conjunto com outras categorias, relativas ao total de citações em cada ano

Figura 14. Proporções de citações das categorias de rejeição, citadas isoladamente ou em conjunto com outras, relativas ao total de citações das categorias em cada ano

Figura 15. Proporções de citações das categorias de aceitação realizadas pelos professores de cada área, contabilizando-se o total de menções, independentemente de terem sido realizadas isoladamente ou em conjunto com outras

Figura 16. Proporções de citações das categorias de rejeição realizadas pelos professores de cada área, contabilizando-se o total de menções, independentemente de terem sido realizadas isoladamente ou em conjunto com outras

Figura 17. Proporções de meninas e meninos aceitos por cada razão, contabilizando-se juntamente as categorias mencionadas isoladamente e as citadas em conjunto com outras 
Figura 18. Proporções de meninas e meninos aceitos por cada razão, considerando-se separadamente as categorias mencionadas isoladamente e as citadas juntamente com outras

Figura 19. Proporções de meninas e meninos rejeitados por cada razão, contabilizando-se juntamente as categorias mencionadas isoladamente e as citadas em conjunto com outras. 100

Figura 20. Proporções de meninas e meninos rejeitados por cada razão, considerando-se separadamente as categorias mencionadas isoladamente e as citadas juntamente com outras

Figura 21. Proporções de citações das categorias de aceitação realizadas pelos professores de cada sexo, contabilizando-se o total de menções, independentemente de terem sido realizadas isoladamente ou em conjunto com outras 103

Figura 22. Proporções de citações das categorias de rejeição realizadas pelos professores de cada sexo, contabilizando-se o total de menções, independentemente de terem sido realizadas isoladamente ou em conjunto com outras 104 


\section{Lista de Tabelas}

Tabela 1. Distribuição, entre as escolas, do número de professores de cada ano escolar que participou do estudo piloto

Tabela 2. Número de indicações de alunas e alunos nas perguntas relativas à aceitação e à rejeição, nos três anos escolares.

Tabela 3. Números e porcentagens de docentes que lecionam em cada área nos três anos escolares

Tabela 4. Número de citações de cada categoria de aceitação, nos três anos escolares 143

Tabela 5. Número de citações de cada categoria de rejeição, nos três anos escolares 143

Tabela 6. Número de indicações de meninas e meninos aceitos pelos professores de cada sexo, conforme o sexo do aluno indicado

Tabela 7. Número de indicações de meninas e meninos rejeitados pelos professores de cada sexo, conforme o sexo do aluno indicado

Tabela 8. Número de indicações de meninas e meninos aceitos pelos professores que lecionam em cada área.

Tabela 9. Número de indicações de meninas e meninos rejeitados pelos professores que lecionam em cada área

Tabela 10. Número de citações de cada categoria de aceitação pelos professores de cada disciplina 145

Tabela 11. Número de citações de cada categoria de rejeição pelos professores de cada disciplina 145

Tabela 12. Número de citações de cada categoria de aceitação, conforme o sexo do aluno indicado .145

Tabela 13. Número de citações de cada categoria de rejeição, conforme o sexo do aluno indicado... 146

Tabela 14. Número de citações de cada categoria de aceitação pelos professores de cada sexo ....... 146

Tabela 15. Número de citações de cada categoria de rejeição pelos professores de cada sexo. 146 


\section{Lista de Apêndices}

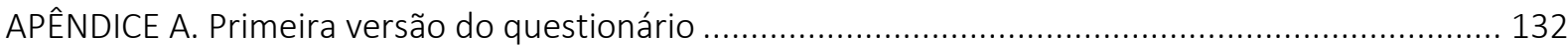

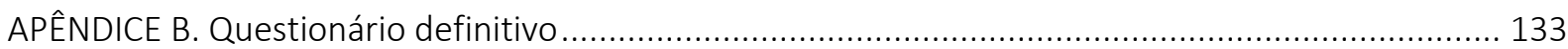

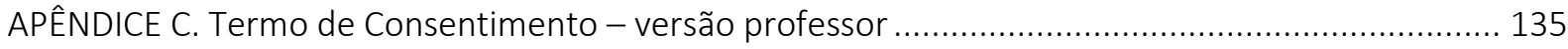

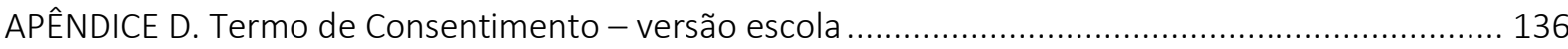

APÊNDICE E. Listas das respostas dos professores fornecidas aos juízes para verificação das categorias

APÊNDICE F. Tabela fornecida aos juízes para verificação das categorias

APÊNDICE G. Tabelas referentes aos dados brutos das análises realizadas nas seções 5.2.2. a 5.2.4. 
Prefácio 
Os problemas vivenciados nos dias atuais - como violência, pobreza, drogadição, criminalidade, desemprego, iniciação sexual precoce, gravidez indesejada, suicídio e dificuldades de relacionamento com família e professores - e suas consequências afetam direta e indiretamente a saúde e o desenvolvimento das crianças e dos adolescentes (Del Prette \& Del Prette, 2006; Roehrs, Maftum, \& Zagonel, 2010). Neste contexto, há preocupação do governo e da sociedade com o desenvolvimento biopsicossocial da criança, sendo por eles proposta a criação de um sistema de proteção para a superação ou minimização desses problemas. Dentre os responsáveis mais diretos por essa proteção, além da família, destaca-se a escola, em função de seu envolvimento extenso com a criança. A escola, ao criar um ambiente seguro e de apoio, pode se tornar um espaço de promoção da saúde, tanto física quanto psicossocial (Roehrs et al., 2010).

Representando a preocupação do governo com o desenvolvimento infantil, o Fundo das Nações Unidas para a Infância (UNICEF) defende uma educação que favoreça esse processo, a partir, por um lado, da proibição de castigos, de palmatórias e de relações autoritárias e, por outro, de medidas que possibilitem procedimentos baseados em relacionamentos afetuosos e respeitosos, prevenindo problemas de relacionamento nocivos ao desenvolvimento e transtornos psicológicos em curto, médio e longo prazos (Del Prette \& Del Prette, 2006; http://www.unicef.org.br/). Apesar dessa preocupação com o papel da escola no desenvolvimento da criança, pesquisas mostram a ineficácia e inadequação dos serviços de educação voltados ao adolescente, pelo fato de os profissionais que lidam com esse público terem pouco conhecimento sobre ele, conhecimento este fornecido de forma insuficiente pelas instituições educacionais (Roehrs et al., 2010).

Considerando a importância da educação na promoção da saúde da criança e do adolescente, os estudos sobre o tema podem se debruçar sobre uma série de variáveis educacionais que podem interferir no desenvolvimento do público infantojuvenil. Ao se explicar os comportamentos do aluno (sejam acadêmicos, sociais ou emocionais), podem-se considerar, por exemplo, suas características sociais, biológicas e psicológicas; os aspectos sociopolíticos da educação; o processo ensinoaprendizagem; o relacionamento entre os alunos; ou a relação professor-aluno (Hamre, Pianta, Downer, 
\& Maschburn, 2008; Del Prette, Paiva, \& Del Prette, 2005; O’Connor, 2010; Pianta \& Walsh, 1996). Conforme Del Prette et al. (2005) defendem, cada uma dessas explicações, isoladamente, é pertinente, mas não explica integralmente o fenômeno, sendo a consideração simultânea dessas análises a base de uma visão sistêmica sobre a educação e a escola. No entanto, entende-se que não é viável uma única pesquisa englobar todos estes aspectos, sendo necessário focar-se em um deles.

Um possível ponto de partida importante na análise e intervenção sobre o sistema escolar pode ser situado nas relações interpessoais que se apresentam neste contexto (e.g. Del Prette \& Del Prette, 2006), haja vista as pesquisas que apontam o impacto dos comportamentos do professor sobre o repertório comportamental dos alunos (e.g. Roorda, Koomen, Spilt, \& Oort, 2011). Segundo Del Prette e Del Prette (2001), no ambiente escolar, as crianças começam a aprender determinados padrões de comportamentos e a ampliar seu conhecimento sobre os diferentes papéis que fazem parte da vida social. Portanto, trata-se de um contexto a partir do qual se desdobra muito do que ocorre posteriormente com a criança e, assim, com a sociedade.

O professor tem deixado de ser apenas o transmissor de informações e vem passando a apresentar um papel cada vez mais complexo e amplo, construindo os conhecimentos junto aos alunos e, deste modo, adquirindo a importante função de possibilitar aos estudantes que integrem, no processo de aprendizagem das disciplinas, os aspectos cognitivo, afetivo e a formação de atitudes (Henklain \& Carmo, 2013; Ribeiro, 2010). Compreende-se, a partir disso, a importância do estudo das interações que a criança estabelece no contexto escolar, especificamente com seus professores, os quais representam - juntamente com os pais e com os colegas - os principais agentes socializadores dos alunos (Del Prette \& Del Prette, 2001; Howes, Hamilton, \& Matheson, 1994; Merritt, Wanless, Rimm-Kaufman, Cameron, \& Peugh, 2012). Estudos sugerem que os pais são importantes para o desenvolvimento social no momento em que a criança entra na escola, mas que a relação professoraluno pode se tornar relativamente mais importante no comportamento posterior do aluno (Runions et al., 2014). 
De forma a contextualizar os objetivos do presente trabalho, o primeiro capítulo consiste em uma revisão da literatura sobre a relação professor-aluno e discorre sobre (1) algumas das classificações utilizadas por autores de diferentes áreas e abordagens para caracterizar essa relação, incluindo a classificação na qual a presente pesquisa se baseia e (2) alguns dos fatores apresentados nas pesquisas sobre o tema como estando associados a interações professor-aluno de alta ou de baixa qualidade. 0 segundo capítulo se refere à Análise do Comportamento, apresentando-se (1) a Análise do Comportamento como a abordagem teórica da psicologia que guia o estudo da relação professor-aluno aqui realizado e (2) os estudos existentes no campo da Análise do Comportamento que investigam o tema. O capítulo seguinte expõe a justificativa, os objetivos e as hipóteses da presente pesquisa. No capítulo 4, é descrito o estudo piloto conduzido com o intuito de testar e aperfeiçoar os métodos da pesquisa, assim como as mudanças que foram feitas a partir dele. Em seguida, no capítulo 5, são apresentados os métodos e os resultados do estudo final, bem como a discussão destes dados. Por fim, o capítulo 6 expõe as limitações do estudo, sugestões para estudos futuros e as considerações finais. 
Capítulo 1 Uma revisão da literatura 


\subsection{A relação professor-aluno segundo a literatura}

Com base em uma revisão da literatura, identifica-se que o tipo de relacionamento entre professor e aluno pode ser sistematizado a partir de diferentes classificações, a depender dos aspectos analisados pelos autores que as sugerem. Del Prette e Del Prette (1999) defendem que, para que se contemple a complexidade envolvida nas relações humanas, sua análise deve levar em consideração as dimensões social, situacional e cultural. No caso específico do relacionamento professor-aluno, a dimensão social corresponderia às características individuais tanto dos professores quanto dos alunos, tais como crenças, habilidades, valores, sentimentos e motivações. A dimensão situacional, por seu turno, se referiria às condições físicas e humanas da instituição escolar, ao projeto pedagógico, à dinâmica organizacional, à autonomia do professor etc. O aspecto cultural, por fim, diria respeito à investigação das dimensões anteriores pautada em regras, normas e valores baseados na filosofia da educação, na política educacional e no papel exercido pela educação e pela escola no contexto sóciohistórico analisado.

Apesar de Del Prette e Del Prette (1999) defenderem esta análise ampla das relações que ocorrem no contexto escolar, observa-se que, por serem muitas as variáveis envolvidas neste fenômeno, os estudos não conseguem abarcar, e nem se espera que consigam, todas as dimensões mencionadas, focando-se em uma delas. Nota-se uma alta frequência de pesquisas voltados às características individuais dos professores e/ou dos alunos, possivelmente pelo fato de ser uma dimensão que apresenta mais possibilidades de atuação e modificação. Algumas das sistematizações dos tipos de relação professor-aluno apresentadas na literatura serão descritas a seguir e, a partir disso, será possível notar o quanto uma única dimensão é suficientemente ampla para que os diversos estudos que se voltam a ela explorem diferentes aspectos.

Silberman (1969), baseado na demonstração de Jackson, Silberman e Wolfson (1969) de que professores apresentam sentimentos distintos em relação a diferentes crianças de sua sala de aula, foi um dos pioneiros a investigar como se dá a relação do professor com seus alunos. O autor buscou 
descobrir diante de quais alunos os professores apresentavam posturas ${ }^{1}$ de afeto, preocupação, indiferença e rejeição. Para isso, fez as seguintes questões, respectivamente, a 10 professoras de $3^{a}$ a série: (1) se você pudesse manter um estudante por mais um ano, por puro prazer, quem você escolheria? (2) se você pudesse devotar toda sua atenção a uma criança que preocupa bastante você, quem você escolheria? (3) se um pai aparecer, sem avisar, para uma conversa, sobre qual criança você estaria menos preparada para falar? (4) se sua classe fosse reduzida em uma criança, quem você ficaria aliviada de ter removida? Após as entrevistas, foram feitas vinte horas de observação da interação entre as professoras e os alunos nomeados, as quais permitiram a obtenção dos seguintes perfis comportamentais de cada tipo de aluno, bem como do professor diante dele:

1) Afeto: eram crianças vistas como quem se conformava às regras, preenchia as necessidades pessoais das professoras (e.g., voluntariavam-se) e demandava pouca energia. Apesar das professoras não interagirem com eles ou não os chamarem mais frequentemente que outros, os elogiavam mais e os usavam como modelo para os colegas.

2) Preocupação: eram crianças que demandavam o tempo da professora de modo extensivo, mas apropriado. Foi o grupo que mais recebeu a atenção das professoras, que iniciavam contatos frequentes, colocavam poucas restrições às crianças - que eram livres para abordá-las em qualquer situação - e elogiavam-nas frequentemente, tomando cuidado para recompensar esforços. Às vezes, expressavam direta e abertamente sua preocupação.

3) Indiferença: essas crianças quase não eram notadas pelas professoras e tinham muito menos contato com elas do que com as outras crianças. Além dessas, não foram encontradas outras diferenças no comportamento das professoras diante dessas crianças.

\footnotetext{
${ }^{1}$ O termo originalmente utilizado na literatura é "attitudes", que pode ser compreendido como um conjunto constituído pelos componentes cognitivo (crenças ou conhecimentos sobre o objeto da postura, tal como "eu acredito que alunos com necessidades especiais pertencem a escolas regulares"), afetivo (sentimentos diante desse objeto, por exemplo "receio que alunos com problemas comportamentais disturbem a ordem da sala") e comportamental (predisposição para agir de uma determinada maneira diante do objeto, tal como "eu me recusaria a dar apoio extra a um aluno com necessidades especiais") (De Boer, Pijl, \& Minnaert, 2011). Pelo fato da tradução "atitudes" poder se referir a uma ação, tornando-se incompatível com essa compreensão global, optou-se, no presente trabalho, pelo uso do termo "posturas".
} 
4) Rejeição: eram crianças percebidas como as que faziam demandas ilegítimas e opressivas. Recebiam críticas frequentes ao abordarem a professora. Eram constantemente vigiadas e controladas. Contudo, as professoras tinham muito contato com elas e frequentemente elogiavam e criticavam-nas em público.

Os resultados do estudo de Silberman (1969) sugerem o quanto as posturas diante de cada aluno - influenciadas por características da criança - afetam os comportamentos do professor, no que se refere às iniciativas de contato com o aluno, às expressões de agrado ou incômodo diante de seu comportamento e à receptividade a solicitações do estudante. Apesar do autor concluir que as posturas de preocupação e indiferença são mais prontamente expressas do que as outras duas, o fato da rejeição e do afeto modificarem as atitudes dos professores diante dos estudantes - e, em consequência, a qualidade da relação estabelecida entre ambos - torna fundamentais estudos referentes a estas posturas.

Os métodos e as descobertas de Silberman (1969) forneceram uma base para diversos estudos posteriores: Brophy e Good (1970), utilizando uma metodologia que se diferenciava à de Silberman (1969) somente pela solicitação de pelo menos três alunos para cada pergunta, buscaram relacionar cada postura ao desempenho acadêmico do aluno. Lago-Delello (1998) utilizou as quatro perguntas visando a estudar as relações entre as dinâmicas da sala de aula e o desenvolvimento de dificuldades emocionais. Cook, Tankersley, Cook e Landrum (2000), Cook (2001) e Cook, Cameron e Tankersley (2007), com o intuito de investigar as posturas dos professores diante de alunos com desabilidades, solicitaram a docentes que preenchessem um formulário, nomeando por escrito três alunos em resposta a cada uma das perguntas de Silberman (1969). Cook e Camaron (2010) estudaram as posturas dos docentes em relação a alunos de inclusão solicitando aos professores que classificassem a veracidade, para cada um de seus estudantes, das afirmações "Eu gostaria de devotar toda minha atenção a esse aluno porque ele me preocupa" e "Se minha classe fosse reduzida, eu ficaria aliviada de ter esse aluno removido". 
Ulteriormente à elaboração das categorias por Silberman (1969), outros autores se dedicaram ao estudo das relações professor-aluno, desenvolvendo novas classificações. Pianta e Steinberg (1992), por exemplo, caracterizam a relação professor-aluno a partir de três aspectos: a proximidade, a dependência e o conflito. A proximidade se refere ao grau de cordialidade e comunicação aberta entre o professor e a criança, podendo funcionar como forma de apoio ao aluno, dado que representa a ligação afetiva entre os dois membros da relação. A dependência consiste na apresentação de comportamentos possessivos por parte da criança, os quais denotam sua necessidade de exclusividade do afeto e da atenção do professor, indicando um excesso de confiança nele como fonte de apoio. Por fim, o conflito corresponde a interações discordantes e falta de harmonia entre professor e aluno (Birch \& Ladd, 1997; Galanaki \& Vassilopoulou, 2007).

Diante da ideia de que todas as crianças biologicamente normais se apegam a adultos que cuidam delas, mas que a qualidade desse apego apresenta variações, Howes e Ritchie (1999) avaliaram as relações professor-aluno na pré-escola e forneceram uma classificação alternativa dessas interações, baseada no apego característico das crianças:

1) Apego evitativo: mostravam mais interesse nos materiais da sala de aula do que no professor; não abordavam o professor e, quando este as abordavam, elas agiam como se não o tivessem notado; quando era solicitado, aproximavam-se do professor, mas logo se afastavam; não chamavam o professor para mostrar algo; quando estavam machucadas ou chateadas, não procuravam o professor ou até se afastavam dele, caso ele tentasse confortá-las;

2) Apego resistente: eram irritáveis e agitadas, choravam frequentemente e era difícil consolálas; agarravam-se ao professor e choravam se ele saía da sala; ficavam facilmente frustradas com tarefas difíceis; demandavam muito dos professores, eram impacientes com eles e não se mostravam satisfeitas com seus esforços para ajudá-las;

3) Apego evitativo-resistente: em alguns momentos, a criança se comporta apresentando apego evitativo e, em outros momentos, apresenta apego resistente; 
4) Apego seguro: aceitavam consolo quando machucadas ou chateadas; abraçavam espontaneamente o professor; tocavam-no gentilmente durante uma brincadeira; compartilhavam prontamente atividades com o professor, mostrando coisas e acolhendo-o na brincadeira; pediam ajuda, quando precisavam; interpretavam a expressão facial do professor quando precisavam de informações; seguiam instruções facilmente e mostravam arrependimento quando o professor falava de mofo firme com elas; mostravam-se felizes com a chegada do professor no início do dia;

5) Apego quase seguro: apresentavam alguns comportamentos evitativos e outros seguros: não confiavam no professor, mas se conformavam prontamente aos procedimentos da sala de aula, de modo que ele não percebesse problemas no relacionamento entre ambos (Bergin \& Bergin, 2009).

Também tomando por base o tipo de apego, mas considerando as interações estabelecidas no Ensino Fundamental e relacionando-os às interações com os pais, Pianta e Nimetz (1991) fizeram uma distinção entre relacionamentos seguros e relacionamentos dependentes. Nos relacionamentos seguros, há sentimentos de confiança e o professor, além de se sentir em sintonia com a criança, percebe que ela se sente segura com ele, que ela buscaria sua ajuda e que ele poderia confortá-la. Os relacionamentos dependentes, semelhantes ao relacionamento resistente descrito por Howes e Ritchie (1999), seriam caracterizados pela percepção do professor de que o aluno busca constantemente sua ajuda ou reafirmação e reage negativamente diante de sua separação (Bergin \& Bergin, 2009).

Outra possível análise da relação entre professores e alunos apresentada na literatura é a de Pianta, LaParo e Hamre (2008), que elaboraram um quadro denominado Classroom Assessment Scoring System (CLASS) para caracterizar as interações professor-aluno com base em três domínios, a saber, o apoio emocional, a organização da sala e o apoio instrucional. O domínio do apoio emocional é composto pelas interações que se refletem no clima emocional da sala de aula (clima este evidenciado pela cordialidade e/ou negatividade presente nessas interações), assim como na conexão emocional entre professor e alunos. Também inclui a consciência e a responsividade do professor ao funcionamento acadêmico e social do aluno e às suas necessidades de desenvolvimento. A organização da sala de aula inclui interações entre professor e aluno envolvidas na organização do tempo, do 
comportamento e da atenção na sala de aula. O apoio instrucional corresponde à qualidade das interações instrucionais entre os envolvidos na relação, em termos da riqueza das instruções fornecidas e do feedback do professor (Bergin \& Bergin, 2009).

Além das classificações expostas acima, todas propostas por autores americanos, vale destacar o trabalho das autoras brasileiras, Batista e Weber (2012), que, a partir de uma revisão da literatura e aplicando o modelo de estilos parentais, categorizaram a relação professor-aluno nos anos iniciais do ensino fundamental com base no que denominaram estilos de liderança dos professores. Para isso, levaram em consideração duas dimensões: a exigência (atitudes dos professores de monitorar e controlar o comportamento dos alunos, impondo limites e regras) e a responsividade (comunicação, envolvimento, reciprocidade e afetividade do professor na sua relação com o aluno). Os estilos considerados na classificação das autoras foram os seguintes:

1) O estilo autoritativo combinaria equilibradamente as duas dimensões, ou seja, o professor apresenta claramente o nível de exigência da escola e da sala de aula a partir do estabelecimento de regras e limites e do monitoramento do comportamento e, simultaneamente, apresenta afetividade nas relações com os alunos estando abertos a trocas com as crianças, elogiando-as quando se comportam de forma adequada, considerando seus sentimentos e suas opiniões, fornecendo alternativas e fazendo-as participar das decisões;

2) O estilo autoritário possuiria uma alta exigência e uma baixa responsividade, sendo característico de professores que valorizam a autoridade, a ordem e a estrutura tradicional sem considerar as demandas dos alunos, que não permitem sua participação nas decisões, que consideram pouco o que eles sentem ou falam e não demonstram interesse ou afetividade por eles;

3) O estilo permissivo, pelo contrário, é caracterizado por alta responsividade e baixa exigência, com professores que não estabelecem regras ou limites e não monitoram os comportamentos dos alunos, não apenas valorizando suas opiniões, mas também deixando-os fazerem o que querem; 
4) No estilo negligente, não há responsividade nem exigência, sendo que os professores não estabelecem regras e limites, mas também não se envolvem com as crianças e não são afetivos com elas.

Vale mencionar, ainda, a categorização criada por Stroet, Opdenakker e Minnaert (2012) com base na Teoria da Autodeterminação (Self-Determination Theory) e frequentemente citada por outros pesquisadores. Os autores holandeses forneceram uma caracterização alternativa da relação professoraluno, levando em consideração o envolvimento dos professores. Esta caracterização seria constituída por quatro componentes: (1) o envolvimento que o professor consegue mostrar a partir da expressão de afeto, (2) a sintonia expressada pelo professor ao mostrar que entende o aluno, (3) a dedicação de recursos, tais como o tempo, ao aluno e (4) a capacidade do professor de garantir que é confiável e que está disponível para oferecer apoio.

As classificações mais mencionadas e utilizadas na literatura, dentre as expostas acima, são as propostas por Pianta e Steinberg (1992) e por Pianta et al. (2008). No entanto, os procedimentos utilizados por esses autores, a depender das condições da pesquisa e de seu delineamento, inviabilizam seu uso, em razão do tempo de preenchimento que demandam dos participantes. Além disso, os instrumentos empregados, em formato de escalas a partir das quais as características dos alunos devem ser avaliadas, muitas vezes limitam as possibilidades de respostas, dificultando o surgimento de dados diferentes dos apresentados pelo próprio instrumento.

O instrumento utilizado por Pianta e Steinberg (1992) para identificar as relações de proximidade, dependência e conflito, por exemplo, consiste em um questionário extenso, o StudentTeacher Relationship Scale (STRS), constituído por 31 itens em formato de escala Likert. No caso do CLASS, são realizadas observações diretas das relações professor-aluno, para as quais são necessários treinamentos específicos. Similarmente, a classificação de Howes e Ritchie (1999) necessita de observações do ambiente escolar para o preenchimento do Attachment Q-Set, além do uso de outras medidas, tal como o STRS. A classificação de Pianta e Nimetz (1991) também toma por base o STRS, juntamente com outros instrumentos que objetivam avaliar medidas diversas. Além disso, estas duas 
últimas classificações são utilizadas por um número significativamente menor de pesquisadores quando comparado com as de Pianta e Steinberg (1992) e de Pianta et al. (2008).

As categorias de Batista e Weber (2012) e de Stroet et al. (2012), por seu turno, não foram identificadas pelos autores por meio da aplicação de nenhum instrumento específico, sendo elaboradas a partir de ponderações teóricas baseadas na literatura existente. A ausência de um instrumento ou procedimento padronizado dificulta a identificação dos tipos de relação professor-aluno referidos pelos autores em uma amostra numerosa, impossibilitando a execução de investigações cujo delineamento exija um número elevado de participantes.

A classificação proposta por Silberman (1969) para caracterizar a relação professor-aluno é obtida a partir da utilização de um instrumento constituído por poucas questões abertas, demandando pouco tempo dos participantes e, assim, aumentando a possibilidade de obtenção de uma amostra maior, condição esta essencial para determinados delineamentos de pesquisa. Considerando isto e o fato dos autores, acima referidos, dos trabalhos ulteriores aos de Silberman (1969) afirmarem que a validade de suas categorias é sustentada pela consistência e pelos padrões diferentes evidenciados nos comportamentos do professor diante do aluno incluído em cada categoria, justifica-se seu uso em pesquisas que tenham por objetivo o estudo das interações professor-aluno.

Como se verá a seguir, os diferentes tipos de relação professor-aluno, incluindo as posturas dos professores categorizadas por Silberman (1969) - afeto, preocupação, indiferença e rejeição apresentam um impacto diferencial e direto nas experiências e oportunidades educacionais vivenciadas pelos alunos (Cook, 2001), o que mostra a importância de investigações que se propõem a compreender aspectos inerentes a tais posturas, no que se refere à sua caracterização, seus motivos e suas consequências. 


\subsection{Fatores associados à qualidade da relação professor- aluno}

\subsubsection{Fatores}

Ajustamento social

Uma das características dos alunos que se mostram associadas à relação professor-aluno é seu ajustamento social, o qual os alunos aprendem tanto por meio de mensagens e direcionamentos explícitos dados pelos professores quanto de forma implícita e indireta, a partir dos modelos e dinâmicas da sala de aula (Bierman, 2011). Este segundo modo de interferir no ajustamento social da criança é referido na literatura a partir da expressão "mão invisível" ("inivisible hand"). Trata-se, segundo Farmer, Lines e Hamm (2011), de uma metáfora utilizada primeiramente para se referir à visão de que os pesquisadores dificilmente consideravam o papel dos professores nos relacionamentos das crianças com seus colegas, a despeito do fato deles frequentemente interagirem, intencionalmente ou não, com os alunos de modo a contribuir com a dinâmica social da sala de aula. A partir das interações com o aluno, os professores influenciariam o comportamento da criança com seus colegas por meio da modelação e do feedback fornecido durante as interações com ela e a partir do apoio e da facilitação, realizados de forma indireta, das experiências entre os pares (Luckner \& Pianta, 2011).

Estudos mostram associações entre, de um lado, a qualidade da relação professor-aluno e, de outro, a aceitação ou a rejeição pelos colegas (e.g. Martinelli \& Schiavoni, 2009). Por um lado, a relação professor-aluno problemática se relaciona à rejeição entre pares (Mercer \& DeRosier, 2008). Por outro lado, no que se refere à aceitação pelos colegas, quanto maior o apoio fornecido pelos professores, maior a eficácia social da criança, sendo sugerido pelas pesquisas que interações professor-aluno caracterizadas por suporte emocional se associam ao comportamento dos pares (Farmer et al., 2011; Gazelle, 2006; Hughes \& Chen, 2011; Hughes \& Kwok, 2006; Rolland, 2012; Wilson, Pianta, \& Stuhlman, 2007). Por exemplo, o estudo de Gest e Rodkin (2011) indicou uma associação entre o apoio fornecido pelo professor e a aceitação social, dado que, em sua pesquisa, professores que expressavam empatia 
e suporte diante de alunos retraídos possuíam salas de aula com menos crianças que não gostavam de seus pares e uma proporção gostar/não gostar maior.

Um dos mecanismos pelos quais a relação entre essas variáveis pode ocorrer seria a partir da queda nos níveis de agressão ocasionada pelo suporte emocional e pela maior proximidade entre professor e aluno (Buyse, Verschueren, Verachtert, \& Van Damme, 2009; Luckner \& Pianta, 2011; Meehan, Hughes, \& Cavell, 2003). Relacionado a isso, pesquisas indicam associações entre relações professor-aluno de baixa qualidade e a vitimização entre pares (Lamas, Freitas, \& Barbosa, 2013; Shin \& Kim, 2008; Troop-Gordon \& Kopp, 2011).

Outro fator que pode mediar a relação entre a interação da criança com o professor e a com os colegas é a influência do professor nas percepções do comportamento do aluno pelos seus pares (Mercer \& DeRosier, 2008). Segundo Hughes e Chen (2011), o educador, a depender do tipo de relação que estabelece com o aluno, influencia as reputações acadêmica e social que a criança terá entre os pares, sendo que este efeito parece aumentar com a idade do aluno. Os autores levantam como hipótese para essa ocorrência o fato dos colegas usarem observações das interações professor-aluno para inferir as habilidades dos estudantes. O professor pode interferir no ajustamento social de seus estudantes por meio de suas práticas em sala de aula - o agrupamento das crianças para passar instruções com base em suas habilidades, as recompensas às respostas corretas ou aos esforços e melhoras, o responder diferencial aos alunos etc. -, as quais podem comunicar aos alunos suas diferenças em habilidades e criar normas e expectativas compartilhadas de como os alunos se relacionam uns com os outros (Hughes \& Chen, 2011).

Alguns estudos, embora em número menor (Laet et al., 2014), sugerem haver a influência inversa, ou seja, que a relação estabelecida com os pares pode interferir nas interações vivenciadas pelos alunos com seus professores. Pesquisas indicam que a rejeição pelos pares prediz a baixa preferência do professor, predição esta que pode ser mais forte do que a predição da rejeição pelos pares a partir da baixa preferência do professor (Hughes \& Chen, 2011; Mercer \& DeRosier, 2008). Destaca-se que o estudo conduzido por Laet et a. (2014) indicou que as predições nos dois sentidos 
ocorrem e são importantes. Também em termos da percepção dos pares, Nesdale e Pickering (2006) conduziram um estudo que indicou que os professores julgavam mais negativamente alunos agressores populares do que os agressores não populares, sugerindo haver uma preocupação em relação à influência que os populares poderiam ter nos demais alunos.

Ainda que o termo "mão invisível" tenha sido originalmente utilizado em referência ao papel do professor nas competências sociais dos alunos e que as evidências indiquem que a mão invisível possui a capacidade de exercer tanto influências negativas quanto positivas na dinâmica social da sala de aula (Farmer et al., 2011), estudos também apontam que ela - a partir de comportamentos de reprimendas ou elogios aplicados sistematicamente pelo docente, por exemplo (Beaman \& Wheldall, 2000) -, apresenta desdobramentos concomitantes e em anos escolares posteriores em outros comportamentos das crianças, tais como seu ajustamento escolar e sua adaptação emocional (Brown, Jones, LaRusso, \& Aber, 2010; Buyse et al., 2009; Furrer \& Skinner, 2003; Hughes, Luo, Kwok, \& Loyd, 2008). As influências e associações com estas e outras variáveis serão exploradas a seguir.

\section{Ajustamento emocional}

A interação professor-aluno se relaciona a aspectos emocionais da criança, por meio, por exemplo, da influência em sua autopercepção: alunos que percebem estar envolvidos em uma relação positiva com o professor, a partir do apoio por ele fornecido, relatam maiores autopercepções de habilidade, de eficácia e de expectativa para o sucesso (Baker, 2006; Rolland, 2012). Além disso, a expressão, pelo docente, de seu envolvimento na vida do aluno, torna o estudante mais propenso a sentir que é cuidado pelo outro e que pertence a um grupo (Ahmed, Winnaert, van der Werd, \& Kuyper, 2010).

Associada a essa questão do sentimento de pertencimento, a solidão é vivenciada pela criança quando o relacionamento com o professor é marcado pela dependência do estudante em relação ao educador e por interações conflituosas entre ambos (Birch \& Ladd, 1997; Galanaki \& Vassilopoulou, 2007; Murray \& Murray, 2004). Ademais, a baixa preferência do aluno pelos seus colegas, a partir da 
mediação da relação com o professor exposta no tópico anterior, pode aumentar o nível de solidão da criança (DeRosier, Kupersmidt, \& Patterson, 1994; Ladd, Birch \& Buhs, 1999; Mercer \& DeRosier, 2008). Em consequência, seu compromisso com o contexto social da sala de aula e com a escola terá prejuízos, juntamente com seu desempenho acadêmico. Portanto, a partir das influências no ajustamento emocional e social da criança, a interação com o professor também se associa a seu ajustamento acadêmico (Hughes \& Kwok, 2007; Osterman, 2000; Rolland, 2012).

\section{Ajustamento acadêmico}

O ajustamento acadêmico - compreendido como sendo a motivação do aluno, a participação nas atividades escolares, suas notas e seus escores em testes padronizados - pode se associar à vivência de relacionamentos de apoio com professores. Tais vivências, quando somadas a outros fatores - tal como a aceitação pelos pares (Ladd et al., 1999) - levam os alunos a possuírem sentimentos de pertencimento à escola, a apresentarem mais atitudes positivas em relação ao conteúdo das disciplinas e aos professores, a se motivarem para participar ativamente e apropriadamente da vida da sala de aula e a apresentarem um bom desempenho escolar e em testes (Furrer \& Skinner, 2003; Hamre \& Pianta, 2001; Patrick, Ryan, \& Kaplan, 2007; Reis, 2005; Rolland, 2012; Skinner, Furrer, Marchand, \& Kindermann, 2008; Thijs \& Verkuyten, 2009; Wesely, 2009; Wubbels, 2007).

Esse efeito do relacionamento do professor com seus alunos pode ser particularmente importante para aqueles que estão em risco de desistir da escola, especialmente durante o Ensino Médio, os quais podem se engajar menos nas atividades escolares. O estudo de Muller (2001) foi um dos que indicaram que o risco do aluno em desistir de aprender depende do nível de preocupação que o professor possui com ele. Uma das explicações para esse efeito consiste no fato do cuidado e da confiabilidade do professor poderem fornecer ao estudante a segurança de que seu investimento na escola terá suporte do comprometimento por parte do professor em apoiar seu sucesso (Muller, 2001). Além dos alunos em risco de desistir, evidências sugerem que os que pertencem a grupos minoritários, os de baixa renda e os com menor habilidade de leitura podem ser especialmente sensíveis a diferenças 
na qualidade das relações que os professores estabelecem com eles, sendo que o apoio emocional do professor pode auxiliá-los a desenvolver repertórios mais favoráveis (Baker, 2006; Burchinal, PeisnerFeinberg, Pianta, \& Howes, 2002; Hamre \& Pianta, 2005; Meehan et al., 2003).

Dados apontados pela literatura também indicam que as relações entre o professor e o aluno parecem melhores no caso de crianças que chegam à escola com habilidades acadêmicas mais desenvolvidas e de alunos sem uma história de fracasso escolar, cujos comportamentos - acadêmicos ou não - são reforçados positivamente pelo docente (Jerome, Hamre, \& Pianta, 2008; Viecili \& Medeiros, 2002). Em contrapartida, a relação é pior quando o aluno possui dificuldades acadêmicas e/ou um histórico com retenções (Azevedo et al., 2012; Baker, 2006), que tem seus comportamentos punidos pelo professor, mesmo quando eles não se referem a atividades acadêmicas (Viecili \& Medeiros, 2002). Relacionado a isso e à questão do ajustamento emocional acima exposto, alunos com desempenho acadêmico insatisfatório podem apresentar um autoconceito prejudicado, por perceberem que seus professores Ihes criticam mais e os veem como bagunceiros, mentirosos e desatentos (Osti \& Martinelli, 2014).

O relacionamento professor-aluno com menos prestação de cuidados, menos apoio e conflitos mais intensos e frequentes compromete o ajustamento escolar do aluno, aumentando as chances de repetência, de desistência da escola e de apresentação de atitudes escolares negativas, menor engajamento e menor cooperação em sala de aula, além de dificultarem o processo de aprendizagem de crianças com dificuldades (Baker, 2006; Birch \& Ladd, 1997; Galanaki \& Vassilopoulou, 2007; Murray, Murray, \& Waas, 2008; Ribeiro, 2010). Estudos apontam que os alunos apresentam um desempenho significativamente menor nas matérias em que os professores os veem como sendo destrutivos, desatentos e que raramente terminam as tarefas, quando comparado a outras matérias (Dee, 2005), sendo que crianças com um relacionamento professor-aluno marcado pelo conflito e pela dependência recebem notas mais baixas que os demais alunos (DiLalla, Marcus, \& Wright-Phillips, 2004). As pesquisas indicam, ainda, que as notas dadas por professor do sexo oposto ao do aluno com quem estabelece 
uma relação conflituosa são ainda menores que as notas dadas por um professor do mesmo sexo (Dee, 2005).

As diferenças observadas no tratamento das crianças com bom ajustamento acadêmico e com mau ajustamento acadêmico podem ser explicadas pelo fato de que o professor pode estimular mais as ações dos alunos aos quais credita a possibilidade de terem um rendimento melhor e estimular menos aqueles que já possuem um histórico de reprovação (Viecili \& Medeiros, 2002). Vale destacar ainda que, conforme revisão de Beaman e Wheldall (2000), o comportamento acadêmico adequado é muito mais provável de atrair elogios e aprovações do professor do que o comportamento social adequado, mas, apesar de ser algo que vem se modificando, o comportamento social inadequado chama mais a atenção do professor, que demonstra sua desaprovação com suas ações.

De forma sistemática, a revisão de Nurmi (2012) apresenta os dois caminhos pelos quais, segundo a literatura, o desempenho acadêmico do aluno pode interferir na sua relação com o professor, especificamente no que se refere às instruções que o educador fornece a seus alunos: o primeiro diz respeito ao paradigma do "Pygmalion" (Rotter, 1967) - a chamada "profecia auto-realizadora" -, cuja ideia central é que os professores dão mais atenção e fornecem mais afeto a alunos dos quais esperam um desempenho bom do que a alunos dos quais esperam um desempenho pobre e, assim, essa distinção seria refletida no aumento da diferenciação entre esses dois grupos de alunos em relação a seu desempenho acadêmico. O segundo meio pelo qual o desempenho acadêmico interferiria na relação se refere à ideia de que os professores ajustam suas instruções de acordo com o desempenho, as habilidades e necessidades do aluno, e não que fornecem tratamento preferencial a alunos de alto alcance, ou seja, os professores dão maior atenção e apoio a alunos com baixo desempenho do que outros alunos pelo fato de precisarem mais (Connor et al. 2009; Corno, 2008).

Além das diferenças nas atitudes do professor diante dos alunos com diferentes desempenhos, os comportamentos diferenciados dos próprios alunos, em termos de engajamento e motivação, podem interferir nas ações do educador (Nurmi, 2012). Por exemplo, alunos altamente motivados para realizar determinadas atividades ou para estudar certas matérias escolares podem ter mais iniciativas 
para interagir com o professor, fazendo perguntas e solicitando mais informações, em comparação com alunos menos motivados.

Problemas de comportamento

Além dos fatores anteriormente expostos, destacam-se as associações entre uma relação professor-aluno de baixa qualidade e o desenvolvimento de problemas de comportamento. Autores indicam que uma relação marcada por discordâncias e falta de comunicação entre professor e aluno pode levar a problemas internalizantes, tais como ansiedade, angústia e depressão, além da solidão já descrita acima (Barrett \& Heubeck, 2000; Galanaki \& Vassilopoulou, 2007; Mercer \& DeRosier, 2008). Além disso, pesquisas mostram que dificuldades nos relacionamentos precoces são indicadores importantes de comportamentos externalizantes ao longo da carreira escolar do aluno, tais como a agressividade, levando a infrações disciplinares e suspensão da escola (Hamre \& Pìnta, 2001). Por outro lado, estudos indicam que uma relação de alta qualidade entre professor e aluno pode prevenir problemas disciplinares no ambiente escolar (Fraser \& Walberg, 2005).

Há também evidências da influência no sentido oposto: em comparação com alunos que não apresentam problemas de comportamento, os que possuem esses problemas em sala de aula são mais propensos a se envolver em relações negativas com o docente (Farmer et al., 2011; Picado \& de Rose, 2009). Estudos indicam que crianças com comportamentos tanto externalizantes (tais como agredir, roubar, gritar, falar ininterruptamente, locomover-se o tempo todo) quanto internalizantes (retraimento, comportamentos ansiosos, timidez etc.) apresentam dificuldade nos relacionamentos sociais e colocam em risco a qualidade da relação com o professor, que se caracteriza por mais conflitos e menor proximidade e apoio sócio emocional (Buyse, Verschueren, Doumen, van Damme, \& Maes, 2008; Henricsson \& Rydell, 2004; Mash \& Barkley, 1996; Murray \& Greenberg, 2000; Nurmi, 2012; Rudasill, Rimm-Kaufman, Justice, \& Pence, 2006; Silver, Measelle, Armstrong, \& Essex, 2005).

Ainda que ambos os tipos de problema de comportamento coloquem em risco a relação com o educador, os externalizantes estão mais comumente associados a uma relação negativa, marcada por 
maior conflito e menor proximidade (Birch \& Ladd, 1998; Henricsson \& Rydell, 2004; Jerome et al., 2008). Isso decorre do fato de que estes comportamentos constituem um desafio para os professores, que não conseguem lidar de forma efetiva com comportamentos antissociais e agressivos, atitudes desafiadoras, desobediência, hiperatividade e falta de concentração nas tarefas, tornando difícil a organização da sala de aula e o processo de ensino (Baker, 2005; Barbosa, Campos, \& Valentim, 2011; Buyse et al., 2008; Del Prette \& Del Prette, 2001; LaPointe, 2003; López, 2004; Marinho, 2003).

Ainda que alunos com problemas de comportamento possam apresentar relacionamentos mais conflituosos e menos próximos com os professores, não são todos os alunos com comportamento desfavorável que formam relações negativas com seus docentes (Buyse et al., 2008). Com base nos fatores expostos nos tópicos anteriores e nos que serão apresentados adiante, compreende-se que é possível que algumas dessas crianças formem relações positivas com os docentes, a depender de outras características que esses alunos possuem, tais como a habilidade em matemática e em linguagem, o sexo do aluno, seu nível socioeconômico e a diferença étnica com o professor (Ladd et al., 1999; Saft \& Pianta, 2001).

Conforme revisão de Fredricks, Blumenfeld e Paris (2004), há evidências empíricas que demonstram a associação concomitante e prospectiva entre os engajamentos comportamental, emocional e cognitivo do aluno, de um lado, e, de outro, seu alcance acadêmico nos ensinos fundamental e médio. Observa-se, portanto, que a relação professor-aluno não possui somente influências diretas em cada um dos aspectos analisados até aqui, mas que os diferentes ajustamentos do aluno também sofrem interferências mútuas. Para além dos fatores do aluno mencionados acima, as pesquisas também se debruçam sobre outras características do estudante, sobre aspectos do professor e da sala ou escola onde ele leciona. Tais variáveis serão mais detalhadas a seguir.

\section{Outras características do aluno}

A etnia do aluno, bem como seu status socioeconômico, são constantemente relatados na literatura como características relacionadas à interação professor-aluno. É apontado que crianças 
pertencentes a grupos de minorias raciais, especialmente americanos de origem africana, e as de baixa renda são menos propensas a desfrutarem de relações de apoio com os professores, os quais apresentam expectativas mais baixas em relação a esses alunos, sendo que essas diferenças parecem aumentar com o passar dos anos escolares (Hughes \& Kwok, 2007; Jerome et al., 2008; Tenenbaum, \& Ruck, 2007). Vale destacar que a etnia e a classe social do aluno não influenciam isoladamente sua relação com o professor, no sentido de que estudos sugerem que as percepções dos professores acerca dos estudantes são mais positivas, bem como seus relacionamentos, para os alunos que possuem as mesmas características raciais que as suas (Jerome et al., 2008; Murray et al., 2008; Saft \& Pianta, 2001).

Por um lado, há pesquisas que indicam que esses padrões refletem estereótipos não acurados, sendo que os alunos negros são vistos como menos capazes e com menores habilidades (Good \& Nichols, 2001; Soares, Fernandes, Ferraz, \& Riani, 2010). Por outro, pesquisadores apontam que eles se originam de características comumente encontradas em alunos de determinados grupos étnicos e socioeconômicos. Por exemplo, crianças de baixo status socioeconômico apresentariam relacionamentos conturbados com os pais, o que dificultaria seu estabelecimento de vínculos no contexto escolar, dado que crianças mal tratadas possuem maior necessidade do apego dos professores e podem ser particularmente propensas a procurar proximidade psicológica do professor, sendo mais difícil para ele gostar delas e dar apoio (Bergin \& Bergin, 2009). Isso vai ao encontro do que Tenenbaum e Ruck (2007) afirmam sobre o fato dos alunos não serem passivos nas salas de aula e poderem levar a certas expectativas e comportamentos dos professores. Neste contexto, os professores podem elogiar mais aqueles que respondem positivamente a elogios ou podem escolher aqueles que frequentemente se voluntariam, por exemplo.

O sexo do aluno é outra variável estudada pelos pesquisadores como passível de influenciar a interação com o professor. Aponta-se que as relações são mais conflituosas e menos próximas com os alunos e a afinidade é maior com as alunas (Baker, 2006; Birch \& Ladd, 1997; Jerome et al., 2008; Kesner, 2000; Rudasill \& Rimm-Kaufman, 2009; Silver et al., 2005), diferenças estas que parecem se acentuar com o passar dos anos (Else-Quest, Hyde, Goldsmith, \& Van Hulle, 2006; Sanson, Smart, Prior, 
Obserklaid, \& Pedlow, 1994). Dentre os possíveis motivos para estas diferenças, os estudos destacam que meninos tendem a ser mais ativos e distraídos que meninas, as quais são menos hiperativas, mais atentas e que, como indicador de afeto positivo, sorriem mais (Kwok, Hughes, \& Luo, 2007; LaFrance, Hecht, \& Paluck, 2003; Mendez, McDermott, \& Fantuzzo, 2002; Silver et al., 2005; Zhou, Lengua, \& Wang, 2009). Além disso, meninos parecem se envolver mais em comportamentos que produzem conflitos (Ladd et al., 1999) e obedecer menos seus professores (Stuhlman \& Pianta, 2002). Devido a esses comportamentos disruptivos, sugere-se que os meninos respondam diferentemente às demandas da escola, de modo que suas habilidades cognitivas, sua motivação e sua maturidade sejam subestimadas, mesmo sendo similares às das meninas (Mullola et al., 2012).

Comportamentos similares são vistos em uma cultura, inclusive pelo professor, como mais apropriados ou menos, a depender do sexo da criança que os apresenta e das expectativas que essa cultura possui acerca dos papeis sexuais (Chen, Rubin, \& Li, 1995; Kerr, 2001; Kerr, Lambert, \& Bem, 1996; Zhou et al., 2009). Tendo isto em vista, compreende-se a necessidade de estudos nacionais que visem a verificar se os comportamentos de meninos e meninas de escolas brasileiras são vistos pelos seus educadores do mesmo modo que os de crianças de instituições escolares de outros países. No entanto, observa-se uma lacuna na literatura nacional, atestada pela frequência relativamente baixa de publicações brasileiras voltadas à investigação da relação entre a percepção do professor e o sexo do aluno, quando comparada ao número de publicações internacionais.

Dentre os aspectos abordados pelos artigos nacionais, destaca-se que os professores não conseguem separar as dificuldades de aprendizagem dos problemas de conduta, de forma a haver um maior encaminhamento de alunos do sexo masculino, em comparação ao de crianças do sexo feminino, a serviços de educação especial (Carvalho, 2001; Carvalho, 2009; Mendes \& Lourenço, 2009). Os autores brasileiros também se debruçam sobre as características específicas de cada gênero, apontando que meninos são vistos pelos docentes como sendo mais inteligentes, mas mais relaxados, indisciplinados, agressivos, provocativos, dispersos e agitados, menos aplicados, assíduos, obedientes e comunicativos no relacionamento professor-aluno, e meninas são percebidas como sendo mais caprichosas, 
cuidadosas, aplicadas, responsáveis, dedicadas, interessadas, atentas, sensíveis, estudiosas, mas menos inteligentes (Da Silva, Barros, Halpern, \& Da Silva, 1999; Gardinal \& Marturano, 2007; Maia, Navarro, \& Maia, 2011). Bolsoni-Silva, Mariano, Loureiro e Bonaccorsi (2013) indicam que meninos, segundo os professores, apresentam mais indicadores de problemas de comportamento que meninas, as quais possuem mais habilidades sociais. Estas autoras também afirmam que as docentes relataram utilizar mais práticas negativas com alunos do que com alunas, resultado este que foi ao encontro dos resultados de Barbosa et al. (2011), cujos professores investigados apresentaram mais afinidade com meninas e mais conflitos com meninos.

Questões familiares também são estudadas no contexto do relacionamento professor-aluno. Abuso, negligência e uso de drogas e álcool por cuidadores podem levar a manifestações mal adaptativas (tais como comportamentos opositores, agressão a colegas e falta de habilidades sociais para solucionar problemas), os quais podem conduzir a resultados negativos a curto e longo prazos, incluindo a rejeição pelos professores (Del Prette \& Del Prette, 2006). Pelo contrário, crianças que vivenciam relações de cuidado com qualidade no ambiente doméstico possivelmente são mais propensas a estabelecer relações mais positivas no ambiente escolar (Jerome et al., 2008).

A presença de necessidades educacionais especiais é outro fator constantemente relatado nas pesquisas. Em termos das categorias de Silberman (1969), as investigações indicam haver um alto número de crianças com desabilidades nomeadas nas categorias de preocupação, rejeição e indiferença e um número baixo de alunos com este tipo de característica na categoria de afeto (Cook, 2004; Cook et al., 2000; Cook et al., 2007). O estudo conduzido por Cook (2001) indicou que, comparando o número de crianças com dificuldades nomeadas nas categorias de rejeição e de indiferença, alunos com dificuldades mais severas eram nomeados com maior frequência na categoria de indiferença, ao passo que os com dificuldades moderadas eram nomeados na categoria de rejeição.

Segundo revisão conduzida por De Boer et al. (2011), pesquisas mostram que, diante de seus alunos com necessidades educativas especiais, os professores possuem posturas negativas (acreditando, por exemplo, que estes alunos não tenham o direito de ser educados na mesma sala de 
aula que os estudantes com desenvolvimento típico) ou posturas neutras (não se posicionando a favor ou contra esse direito, por exemplo). Conforme Fragoso e Casal (2012) apontam, os docentes discriminam as crianças com necessidades educativas especiais, em geral decorrentes de preconceitos relacionados à falta de informação e de dificuldades de aceitação da diferença e das limitações físicas e com a falta de higiene desses alunos. Neste sentido, a postura do professor diante de seus alunos com necessidades especiais dependerá não somente da condição da criança, mas também da disponibilidade dos recursos necessários para lidar com esses alunos, tal como a presença de um paraprofissional em sala de aula (Cook et al., 2007) - raro no contexto brasileiro -, e de características do próprio professor, tais como gênero, experiência como professor, experiência e treinamento para trabalhar com alunos de inclusão, atitudes em relação ao ensino em geral e conhecimento sobre inclusão (Bayliss \& Avramidis, 2000; Gomes \& Barbosa, 2006; Kuester, 2000; Stancic, 2000).

Há, ainda, estudos que sugerem haver uma influência da aparência física do aluno na expectativa que os professores possuem acerca de seu desempenho acadêmico e relacionamento social (Clifford \& Walster, 1973; Dusek \& Joseph, 1983; Soares et al., 2010). Entretanto, não se sabe a duração desses efeitos, podendo se tratar de uma característica que interfere nas expectativas iniciais dos professores, mas que perdem o efeito depois que eles obtêm outras informações mais importantes (LaVoie \& Adams, 1974).

\section{Características do professor}

O sexo do professor também parece influenciar na determinação de suas expectativas e dos relacionamentos estabelecidos: a revisão de Li (1999) apontou evidências de que professoras apresentam crenças mais estereotipadas acerca dos alunos e das alunas. Os professores, por sua vez, tendem a acreditar que a matemática é um domínio masculino, crença estas que têm se refletido na pontuação que dão à capacidade dos alunos, em suas maiores expectativas para os do sexo masculino e suas posturas mais positivas diante deles. Os professores homens percebem, mais que as professoras, a persistência, a competência educacional, a distração e a inibição como sendo características próximas, 
tanto em alunos quanto em alunas (Mullola et al., 2012). Não somente isto, mas as professoras são mais propensas a fornecerem ambientes mais colaborativos de aprendizagem (Li, 1999).

Ressalta-se também que o professor de sexo oposto ao da criança, em comparação ao professor do mesmo sexo que ela, é mais susceptível a percebê-la como mais desatenta, destrutiva, com menor desempenho e engajamento e que não faz a lição (Dee, 2005, 2007; Mullola et al., 2012). Com base nisso, tem sido questionado se o maior número de professoras seria a explicação para o baixo alcance acadêmico dos meninos e se eles precisariam de professores homens para melhorar seu desempenho ou para assumir um papel de modelo masculino (Mullola et al., 2012).

Outras variáveis do professor investigadas como fatores que interferem na relação estabelecida com os estudantes se referem às suas crenças e atribuições. Em relação ao desempenho acadêmico do aluno, pesquisas indicam que as posturas dos professores são influenciadas pelas crenças que possuem acerca da maleabilidade da inteligência, bem como por suas percepções referentes à competência do aluno e ao motivo de seu mau desempenho (Good \& Nichols, 2001; Kos, Richdale, \& Hay, 2006). Quando o professor compreende que o mau desempenho poderia ter sido evitado pelo aluno (por exemplo, por achar que foi resultado da falta de estudo), a relação entre ambos pode se tornar prejudicada, podendo haver punição severa. Todavia, quando o professor atribui as causas do mau desempenho a fatores incontroláveis (por falta de capacidade ou porque considera a prova aplicada difícil, por exemplo), ele presta mais auxílio ao aluno (Bzuneck \& Sales, 2011; Matteucci, 2007; Reyna \& Weiner, 2001).

Considerando crianças que apresentam problemas de comportamento, a postura do professor parece sofrer influências de sua experiência com elas, bem como de seu conhecimento sobre esses problemas e de sua aceitabilidade e tolerância diante desses comportamentos (Kos et al., 2006). Ainda que alguns estudos apontem pequena relação entre, de um lado, a experiência e o nível educacional do professor e, de outro, os relatos de alunos e professores acerca da qualidade de seus relacionamentos (Stuhlman \& Pianta, 2002; Wentzel, 2003), outros pesquisadores indicam que professores com maior nível educacional tendem a desenvolver relacionamentos melhores e, aqueles com mais experiência, 
relacionamentos piores (Hearns, 1998; Mashburn, Hamre, Downer, \& Pianta, 2006; O'Connor, 2010; O’Connor \& McCartney, 2006).

A interação professor-aluno também é afetada pela história pessoal de relacionamentos do educador, bem como por suas habilidades sociais e dos conhecimentos que possui acerca das transformações inerentes às fases do desenvolvimento infantil (Kesner, 2000; Meireles, 2009; Roehrs et al., 2010). O uso de práticas de ensino apropriadas ao nível de desenvolvimento do aluno, de diálogos instrucionais entre professor e aluno e de altos níveis de feedback avaliativo e de instruções em grupo contribui para o estabelecimento de relações professor-aluno de alta qualidade (Donohue, Perry, \& Weinstein, 2003; Emmer \& Stough, 2001; Mantzicopoulos, 2005; O’Connor, 2010).

A idade do professor consiste em outro fator apontado na literatura como passível de influenciar sua relação com o estudante. O estudo de Mullola et al. (2012) indicou que, quanto mais velho o professor, mais percebe o aluno como sendo maduro. Este estudo também sugeriu haver uma interação entre a idade do professor e seu sexo: a idade do professor homem diminuiria sua percepção de humor nos meninos e aumentaria a percepção de sua inibição. Ademais, com a idade, o professor homem se tornaria mais intolerante com os meninos, mas, com as professoras, esse desenvolvimento relacionado com a idade não ocorreria.

Vale destacar, ainda, que a saúde mental do professor também é indicada como fator que possui um papel na relação estabelecida com os alunos. Segundo Hamre e Pianta (2004), por exemplo, professores que relatavam mais sintomas depressivos eram mais propensos a se engajar em interações negativas com alunos jovens.

\section{Características da sala e da escola}

Além dos fatores do aluno e do professor acima relatados, há também variáveis da sala na qual o professor leciona e da instituição escolar que são relevantes para essa relação. Dentre os aspectos apontados na literatura, pode-se mencionar o perfil da turma, ou seja, o percentual de alunos da sala que apresentam determinada característica (Soares et al., 2010), tais como alto nível de habilidade 
acadêmica ou comportamentos de fácil manejo (Brophy, 1983; Heller \& White, 1975). Sugere-se que o conflito na relação do professor com o aluno que possui problemas de comportamento internalizantes ou externalizantes é intensificado quando a sala de aula é, como um todo, altamente desafiadora (Buyse et al., 2008).

Em termos do contexto escolar, pode haver influência das ações dos demais profissionais que trabalham na instituição, incluindo os outros professores, bem como dos valores, das ideologias e normas estabelecidas na escola, seja em termos mais gerais - por exemplo, a imposição de avaliações - ou as estabelecidas em escolas específicas - tal como seria o caso das instituições que não possibilitam uma maior interação entre professor e aluno (Bergin \& Bergin, 2009; Tacca \& Branco, 2008).

Ainda, a escola privada possibilita relacionamentos diferentes dos apresentados na escola pública, em razão dos salários diferenciados, dos níveis de exigência cobrados do professor em cada um desses contextos, do número de alunos para os quais se dá aula, bem como das características dos alunos que os frequentam, em termos tanto de condições socioeconômicas quanto de dificuldades de aprendizagem (Akkari, 2001; Hall \& Cassidy, 2002; O’Connor, 2010; Pianta et al., 2005; Soares, Naiff, Fonseca, Cardozo, \& Baldez, 2009). Além do apoio financeiro, as escolas que fornecem mais oportunidades ao professor de crescimento profissional possuem docentes que desenvolvem melhores relacionamentos com os alunos (Fontaine, Torre, Grafwallner, \& Underhill, 2006; O’Connor, 2010).

Ano escolar

Os estudos indicam que os benefícios de uma interação professor-aluno positiva ocorrem desde os anos escolares inicias até o período da adolescência (Howes et al., 1994; Ryan, Stiller, \& Lynch, 1994; Wentzel, 1998), tanto no sentido das vantagens imediatas quanto das que se apresentam a longo prazo. Levando em consideração o ajustamento em médio e longo prazos, relativo aos padrões de engajamento, de motivação na escola e de desempenho acadêmico, as relações estabelecidas mais precocemente podem ser particularmente importantes (Hamre \& Pianta, 2001; Hughes et al., 2008; Ladd et al., 1999). Ainda assim, os alunos necessitam do apoio desse relacionamento em momentos de 
transição, tal como na passagem do Ensino Fundamental I para o Ensino Fundamental II (Kosir \& Tement, 2014; Wentzel, 1998). Além disso, os relacionamentos em idades mais avançadas permanecem interferindo no ajustamento do estudante, inclusive no que se refere a seus sentimentos de afinidade e de pertencimento à escola (Ahmed et al., 2010; Osterman, 2000), a seu desempenho acadêmico (Niehaus, Rudasill, \& Rakes, 2012) e ao auxílio que alunos vulneráveis recebem dos professores para adquirir apoio de seus pares (Bierman, 2011).

Alunos com maior proximidade com seus professores durante o Ensino Médio apresentam níveis mais baixos de sofrimento emocional, ideação suicida, comportamento suicida, violência, abuso de substâncias e atividade sexual precoce (Resnick et al., 1997). Assim como ocorre com alunos mais jovens, os estudantes de anos escolares mais avançados (por exemplo, a partir da 8a série) que possuem apoio do professor têm benefícios em seu alcance acadêmico, sendo a relação com o professor mais preditora desse aspecto do que a relação de apoio com os pais (Gregory \& Weinstein, 2004). Enquanto, nos anos inicias, os professores são importantes para estruturar as experiências diárias dos alunos, regular suas emoções e comportamentos e facilitar a interação com os pares, a função do relacionamento com o professor passa a ser, com o passar dos anos, o fornecimento de ligações com recursos de fora da sala (Hamre \& Pianta, 2006).

Apesar da importância do apoio do professor ao longo de todos os anos escolares, são vários os estudos que apontam que, no início da escolarização, o relacionamento professor-aluno tende a ser melhor e se caracterizar por mais afinidade e menos conflito, piorando com o passar dos anos (Azevedo et al., 2012; Barbosa et al., 2011; Brophy, 1983; Irvine, 1986; Jerome et al., 2008; Lamas et al., 2013; Murray-Harvey \& Slee, 2010). Na educação infantil, há um maior envolvimento por parte dos professores, que apresentam mais habilidades sociais e, com maior frequência, atitudes de cuidado e proximidade física (Maia, Soares, \& Victoria, 2009; Soares et al., 2009). As interações com os professores se tornam, com o passar dos anos escolares, menos estáveis, menos próximas e pessoais e menos fornecedoras de apoio emocional (Harter, 1996; Lynch \& Cicchetti, 1997). Em anos escolares mais elevados, os professores lidam menos com os problemas de comportamento de seus alunos, sendo 
mais avaliativos e estando mais focados em seu desempenho acadêmico, de forma a exercerem menor influência em suas amizades (Bierman, 2011).

Sugere-se que a afetividade na relação professor-aluno é mais negligenciada em níveis mais avançados pelo fato da criança ser cada vez mais capaz de monitorar e controlar seu próprio comportamento, sem precisar de um feedback constante do educador (Jerome et al., 2008). Ademais, muitas escolas de Ensino Fundamental II abordam as necessidades sociais e instrucionais dos alunos a partir de uma perspectiva cujo objetivo é o gerenciamento. A organização e as técnicas direcionadas ao controle acabam levando a uma menor motivação, um menor engajamento e uma maior hostilidade do aluno (Hamre \& Pianta, 2006).

Segundo Maia et al. (2009), talvez essa tendência seja facilitada pela valorização das relações interpessoais que se iniciam nos primeiros anos escolares e pelos aspectos lúdicos presentes neste momento do desenvolvimento infantil. Além disso, o fato dos educadores de séries iniciais, por serem polivalentes, permanecerem mais tempo com os seus alunos também pode facilitar o estabelecimento de uma relação professor-aluno positiva, diferente do que ocorre a partir do Ensino Fundamental II, no qual passa a haver um professor para cada matéria e, consequentemente, menos tempos de contato com os estudantes (Bergin \& Bergin, 2009; Hamre \& Pianta, 2006; Jerome et al., 2008).

Conforme Jerome et al. (2008) defendem, apesar dos alunos precisarem de mais apoio e de uma relação mais positiva com os professores durante a transição do Ensino Fundamental I para o Ensino Fundamental II, essas relações podem estar menos disponíveis neste momento, havendo uma queda em sua qualidade. Sendo assim, torna-se importante compreender os fatores que influenciam a mudança dessas relações, fatores estes investigados por poucas pesquisas.

\subsubsection{Conclusões}

A análise dos estudos que compuseram a revisão da literatura apresentada neste primeiro capítulo possibilita notar diferenças quantitativas e qualitativas entre os estudos nacionais e internacionais mencionados. As pesquisas internacionais são consideravelmente mais numerosas e, em 
geral, apresentam um maior rigor metodológico. Ainda que se observe que seus resultados são similares, o que sugere proximidade entre as condições educacionais dos diferentes contextos em que os estudos foram conduzidos, torna-se importante incrementar a literatura nacional com novas pesquisas, visando a verificar a veracidade deste dado e suas implicações.

Nota-se, ainda, que grande parte dos estudos que investigam a relação professor-aluno é pautada em orientações teóricas diferentes da Análise do Comportamento (AC) ou é destituída de uma abordagem teórica específica. Isso indica uma importante lacuna no conhecimento da AC e sugere a necessidade de um maior investimento, por parte dos pesquisadores analítico comportamentais, neste campo de estudos. O próximo capítulo se debruçará sobre essa abordagem, propondo-se a explicar alguns de seus pressupostos e conceitos importantes, de forma a exemplificar alguns estudos analíticocomportamentais voltados à área, e a demonstrar as contribuições que este braço da psicologia pode fornecer ao tema da relação professor-aluno. 


\section{Capítulo 2}

Análise do Comportamento 


\subsection{Análise do Comportamento: um possível recorte teórico}

O tema da relação professor-aluno, seja em termos das expectativas dos educadores, de suas atitudes ou do processo educacional no geral, pode ser estudado a partir de diversas abordagens teóricas da psicologia. Algumas delas, ao explicarem os fenômenos que ocorrem no contexto escolar, dão maior importância às variáveis associadas ao professor, enquanto outras se focalizam nas variáveis dos alunos (Good \& Nichols, 2001); algumas buscam no próprio indivíduo as causas dos comportamentos dos alunos ou dos professores, ao passo que outras compreendem que as razões do comportamento desses agentes estão nas condições ambientais (Zanotto, 2000). As explicações voltadas à natureza interna do próprio indivíduo - as chamadas mentalistas - são majoritárias na área da educação, e a AC - que traça, com seus pressupostos filosóficos, o caminho contrário a essas teorias dominantes - ocupa um espaço restrito nessa área.

A AC é uma ampla área que se constitui por três pilares: o Behaviorismo Radical, correspondente ao braço teórico, filosófico e histórico; a Análise Experimental do Comportamento, referente ao braço empírico; e a Análise Aplicada do Comportamento, que consiste na criação e administração de recursos de intervenção social (Tourinho, 1999). Esses três pilares se unem a partir da pesquisa empírica, por meio da qual são obtidos conceitos a serem utilizados na interpretação tanto de situações nas quais se podem realizar experimentos quanto naquelas em que isso não pode ser feito, tal como no estudo sobre a origem das verbalizações privadas (Donahoe, 1993).

Tendo em vista essa base empírica da AC, um de seus fundamentos se assenta na crítica ao mentalismo. Segundo os analistas do comportamento, as explicações mentalistas, ao colocarem o foco das causas do comportamento no interior dos organismos, impedem investigações acerca daquilo que consideram reais determinantes dos comportamentos - ou seja, os aspectos hereditários e ambientais - e, por conseguinte, dificultam a elaboração de explicações científicas satisfatórias (Baum, 2006). Com base nisso, defende-se a inexistência de uma mente ou de eventos mentais como agentes internos 
responsáveis pelas ações dos indivíduos, compreendendo-se a subjetividade como sendo constituída por pensamentos, sentimentos e sensações que não possuem uma natureza diferente da natureza físico-biológica das ações - andar, falar, chorar etc. - do organismo (Tourinho, 2003).

Neste sentido, pode-se afirmar que a subjetividade é um conjunto de elementos que, assim como as ações dos indivíduos, fazem parte dos chamados comportamentos. O conceito de comportamento tem sido discutido, na AC, há décadas (Botomé, 2001), mas pode-se afirmar, em termos gerais, que o comportamento de um organismo é uma relação entre o que ele faz e os ambientes antecedente e consequente a esse fazer. A partir dessa definição, entende-se que, além da subjetividade não se configurar como causa das ações, ambas - subjetividade e ações do indivíduo são explicadas a partir de fenômenos ambientais. Esses fenômenos ambientais explicariam o comportamento dos indivíduos como sendo produto de três histórias (Melo, Dittrich, Moreira, \& Martone, 2013a, 2013b; Dittrich, Melo, Moreira, \& Martone, 2013; Skinner, 1990, 1953/1998):

(1) a filogenética: o processo evolucionário de uma espécie, no qual, a partir da variedade genética presente em uma espécie, aquelas variações que tornam o organismo mais bem adaptado ao meio em que vive possuem maiores chances de serem selecionadas e perpetuadas na espécie em questão, visto que o organismo com estas características terá maiores chances de sobreviver, reproduzir-se e transmitir seus genes a seus descendentes.

(2) a ontogenética: a história de vida do indivíduo, na qual as consequências ambientais de seus comportamentos permitem a aquisição de novos comportamentos, a extinção de antigos ou o aumento de sua eficiência, constituindo-se, assim, seu repertório comportamental.

(3) a cultural: as práticas culturais se iniciam com um indivíduo que foi capaz de solucionar algum problema da sociedade ou instituir atividades importantes para a sobrevivência de seu grupo. A partir disso, as consequências reforçadoras refletem sobre o grupo como um todo, possibilitando a transmissão dessas práticas para as gerações seguintes e permitindo a evolução da cultura.

Observa-se, portanto, que a AC compreende que o indivíduo modifica o meio na medida em que é modificado por ele, em uma relação de interdependência mútua (Skinner, 1953/1998). 
Especificamente, tem-se como um dos conceitos centrais na teoria analítico-comportamental a noção de contingência de reforço. Trata-se de um termo que, no contexto da AC, se refere a qualquer relação de dependência entre os eventos ambientais ou entre os eventos ambientais e comportamentais (Skinner, 1953/1998) e envolve a especificação da relação entre três eventos: (1) os estímulos ambientais antecedentes, ou seja, a ocasião em que a resposta do organismo ocorre, (2) a resposta do organismo e (3) os estímulos ambientais consequentes produzidos pela resposta (Todorov, 1985).

Tendo estas concepções como base, o objetivo fundamental da AC consiste na descrição das relações indivíduo-ambiente, de forma a identificar as variáveis controladoras do comportamento antecedentes e consequentes - e possibilitar a compreensão do motivo pelo qual as pessoas agem da forma que agem nas circunstâncias em que agem (Henklain \& Carmo, 2013). Para que essa compreensão ocorra, os analistas do comportamento dispõem da Análise Funcional ou Análise de Contingências, que consiste na identificação da função do comportamento a partir da descrição do contexto em que ele ocorre e das consequências produzidas por ele (Moreira \& Medeiros, 2007).

A importância de se entender desta forma os comportamentos reside no fato de que, conhecendo-se suas variáveis controladoras, é possível lidar com eles de modo mais eficiente, ou seja, pode-se prevê-los e controlá-los (Skinner, 1953/1998). Como afirma Skinner (1953/1998), quanto mais o indivíduo conhece as variáveis que afetam seus comportamentos, maior a possibilidade dele alterar seu futuro. 


\subsection{A relação professor-aluno sob a ótica da Análise do Comportamento}

No contexto escolar, a interdependência mútua entre organismo e ambiente, acima citada, está presente na interação entre professor e aluno: os comportamentos do professor influenciam os comportamentos do aluno e são influenciados por eles, em uma situação na qual um se configura como ambiente para o outro (Batista \& Weber, 2012). A Figura 1 exemplifica a ideia de que o aluno se configura como ambiente para o professor e vice-versa, apresentando uma esquematização de relações de contingência entre as respostas do docente e as respostas do estudante, na situação de ensino.

\begin{tabular}{|c|c|c|}
\hline Situação antecedente & $\Rightarrow \quad$ Classe de respostas do & Situação consequente \\
\hline $\begin{array}{l}\text { - Objetivos de ensino } \\
\text { definidos (descrição do } \\
\text { desempenho final do } \\
\text { aprendiz ou de outras } \\
\text { concepções de objetivos, do } \\
\text { professor) } \\
\text { - Características dos } \\
\text { aprendizes: capacidade de } \\
\text { desempenho inicial dos } \\
\text { aprendizes, interesses etc. } \\
\text { - Matérias e condições de } \\
\text { ensino }\end{array}$ & $\begin{array}{l}\text { Qualquer classe de respostas } \\
\text { do professor }\end{array}$ & $\begin{array}{l}\text { - Desempenho do aprendiz, } \\
\text { de acordo com os objetivos } \\
\text { definidos pelo professor } \\
\text { - Outros desempenhos do } \\
\text { aprendiz }\end{array}$ \\
\hline
\end{tabular}

Figura 1. Explicitação esquemática de componentes constituintes do comportamento "ensinar" para exemplificar como esses componentes constituem a relação (entre situação antecedente a uma classe de respostas, a própria classe de respostas e a situação consequente a essa classe de respostas). Adaptado de Kubo, O. M., \& Botomé, S. P. (2001). Ensino-aprendizagem: uma interação entre dois processos comportamentais. Interação em Psicologia, 5(1), 131-171.

Segundo Zanotto (2000), é na interação com o aluno e em função do efeito do comportamento do professor sobre o comportamento do aluno - compreendido, neste contexto, como ambiente para o professor - que o comportamento do educador é alterado ou mantido. Por exemplo, comportamentos do aluno que se constituem como reforçadores pessoais do professor (tais como a bajulação), podem ser por este reforçados, de forma a aumentar a frequência dessas atitudes dos 
alunos, mesmo que sejam inadequadas. O aumento na frequência desses comportamentos, por sua vez, poderá levar os professores a reforçarem-nos com maior probabilidade.

Outro exemplo no qual o aluno se constitui como ambiente para o comportamento do professor é quando ele apresenta um bom desempenho acadêmico e um progresso em seu aprendizado após o trabalho do educador, aumentando as chances do professor continuar emitindo seu comportamento de ensinar (Kubo \& Botomé, 2001; Ulrich \& Kubo, 2004). Segundo Zanotto (2000), contingências de reforçamento positivo explicam a manutenção de certos comportamentos de professores que aprenderam, em sua história de vida, a ficar sob controle do bom desempenho do estudante, tais como ver o aluno acertar, levá-lo a esclarecer uma dúvida e manter um relacionamento amistoso.

Vale destacar que o aluno não se constituirá como ambiente somente no sentido de ter seu comportamento como consequência das atitudes do professor, mas também adquirindo a função de estímulo antecedente, ou seja, de ocasião que possibilita a emissão de determinados comportamentos pelo professor (Kubo \& Botomé, 2001). Por exemplo, a depender da idade, das habilidades e das características físicas e biológicas do aluno, o professor poderá apresentar um comportamento diferenciado, adaptando suas estratégias de ensino às necessidades do aluno. Similarmente, os recursos disponíveis para o professor, as regras da escola e os objetivos curriculares também adquirem a função de ocasião para a emissão de certos comportamentos, os quais não ocorreriam se as condições em que trabalha fossem diferentes.

Uma das maneiras pelas quais o professor se torna ambiente de seu aluno é a partir das punições e dos reforçadores que o educador fornece aos comportamentos emitidos pelos estudantes, o que leva, respectivamente, à diminuição ou ao aumento da frequência da emissão desses comportamentos (Del Prette \& Del Prette, 2006). A depender do modo como essas punições e esses reforçadores são fornecidos, podem aumentar os riscos de problemas de comportamentos internalizantes e externalizantes. Segundo os autores, a consequenciação aos comportamentos inadequados dos alunos, somada à não responsividade dos professores diante de comportamentos 
desejáveis, não apenas enfraquece as tentativas do estudante de se engajar aos estudos, como também aumenta a probabilidade da emissão de comportamentos indesejáveis (Del Prette \& Del Prette, 2006). Associado ao desenvolvimento e aumento da emissão de comportamentos inadequados, e estabelecendo um paralelo com as variáveis, expostas no capítulo anterior, relacionadas à qualidade da relação entre professor e aluno, vale abordar o que os autores da AC ponderam sobre a função das interações negativas entre professor e aluno. O uso da coerção em sala de aula produz fracasso escolar e situações aversivas (tais como uso de castigos, retirada de privilégios e humilhação) geram medo, ansiedade e raiva (Hübner, 2005; Sidman, 1989/2009; Skinner, 1972/1975; Ulrich \& Kubo, 2004). A aversividade presente na relação professor-aluno também pode levar ao contracontrole dos alunos, ou seja, comportamentos de fuga e esquiva emitidos para que eles se defendam contra as medidas severas adotadas pelo educador (Hübner, 2005; Sidman, 1989/2009; Skinner, 1972/1975, 1989/2005; Viecili \& Medeiros, 2002). Dentre esses comportamentos, os autores destacam os atrasos, as conversas com colegas, a falta de atenção às explicações, os atos violentos contra a escola e os pares e o abandono escolar. Interações coercitivas produzem sentimentos de desamparo e gerando baixa produtividade e alterações nas condições de saúde dos professores e alunos (Ulrich \& Kubo, 2004).

Diante dos prejuízos associados a uma interação negativa entre docente e aluno, entende-se a importância de se estabelecer um relacionamento positivo entre ambos, tal como é defendido por analistas do comportamento. Ulrich e Kubo (2004), por exemplo, afirmam que relações reforçadoras, nas quais há confiança mútua entre professor e alunos e respeito ao ritmo e à forma de aprender dos estudantes, geram mudanças comportamentais que possibilitam o desenvolvimento de sua capacidade em atuar em seu ambiente social, além de permitir, a partir da eliminação da punição, a existência de melhores condições de saúde tanto para os professores quanto para os alunos.

Ainda, as autoras defendem a importância de fazer com que a aprendizagem seja reforçada por si mesma, ao evitar a punição por desempenhos inadequados ou insuficientes e ao oferecer oportunidades para que o aluno apresente o máximo desempenho que puder em cada etapa e se sinta reforçado ao concluí-las (Ulrich \& Kubo, 2004). Similarmente, Rodrigues (2005), em sua revisão das 
teses e dissertações relativas à contribuição da AC para a formação de professores, salienta a importância referida na literatura da minimização ou eliminação de contingências aversivas em sala de aula, bem como do estabelecimento adequado de contingências reforçadoras, a partir do uso de reforçadores naturais, imediatos e contingentes ao comportamento do aluno e da identificação dos estímulos que funcionam como reforçadores para cada estudante.

A despeito dos efeitos deletérios da coerção e dos benefícios do reforçamento positivo de comportamentos adequados, o professor usualmente atua com maior frequência nos comportamentos inadequados dos alunos, dando maior atenção a estas atitudes e não se atentando aos comportamentos adequados. Ademais, as técnicas coercivas são as mais utilizadas pelos professores para manter a disciplina, visto que produzem de forma mais imediata alunos disciplinados, obedientes e aplicados, ainda que estes comportamentos se mantenham somente na presença do agente punidor ( $D^{\prime}$ Oliveira, 1998; Ulrich \& Kubo, 2004).

Sob o ponto de vista, defendido até aqui, de que o professor e o aluno são ambientes um para o outro, torna-se possível analisar os problemas de ensino não mais como decorrentes exclusivamente de características do próprio aluno ou de características do professor, mas de condições de seu ambiente, o qual também é responsável por determinar essas características do estudante e do docente (Rodrigues, 2005; Viecili \& Medeiros, 2002; Zanotto, 2000). Tendo isto em vista, entende-se que, ao serem ensinados a analisar os fenômenos escolares com base em teorias mentalistas, os educadores acabam por não identificar suas próprias ações como sendo parte importante da determinação dos comportamentos de seus alunos. Deste modo, dificulta-se a mudança nessas condições e, consequentemente, nos comportamentos dos alunos (Rodrigues, 2005; Zanotto, 2000). Não apenas isto, mas o próprio professor passa a ser culpado pelo insucesso em ensinar: sua incompetência, dificuldade de compreensão e falta de motivação são o foco das críticas, sendo o ambiente que propiciou tais problemas negligenciado.

De fato, a partir dessa dinâmica que ocorre em sala de aula, é possível compreender a importância que a abordagem da AC pode adquirir no momento de delinear intervenções no contexto 
escolar. Vários procedimentos têm sido estudados e aplicados para reduzir ou eliminar comportamentos inadequados das crianças na escola, sendo que os procedimentos são usualmente aplicados com o objetivo de melhorar a interação entre o aluno e o professor. Uma das possibilidades de intervenção é baseada na análise funcional do comportamento, que, ao possibilitar a identificação de condições ambientais antecedentes e consequentes que mantêm os comportamentos disruptivos ou desafiadores, permite o delineamento de intervenções que se foquem em alterações no ambiente do aluno. Estas alterações, por exemplo, podem ser promovidas por meio do ajustamento dos estímulos antecedentes, do reforçamento de comportamentos adequados e/ou da extinção de comportamentos inadequados (Janney, Umbreit, Ferro, Liaupsin, \& Lane, 2013; Lane, Smither, Houseman, Guffey, \& Fox, 2007). É importante destacar que pesquisas indicam que as intervenções que tomam como base a análise funcional são mais efetivas do que as que não o fazem (Janney et al., 2013; Lane et al., 2007).

Conclui-se, a partir do exposto até aqui, que a AC fornece um subsídio teórico-conceitual que possibilita identificar a importância de compreender como ocorrem e quais são as variáveis controladoras das atitudes do professor e do aluno, ao funcionarem como ambiente um para o outro: sabendo-se o que determina os comportamentos do professor, possibilita-se identificar o que deve ser alterado para que suas atitudes se modifiquem e, assim, o comportamento do aluno também se altere. 


\section{Capítulo 3}

O estudo: justificativa, objetivos e hipóteses 


\subsection{Justificativa}

Diante das informações apresentadas nos capítulos anteriores, observa-se concordância com o que O'Connor (2010) defende acerca do fato de que os pesquisadores especulam que a qualidade da relação entre o professor e o aluno é determinada por interações complexas entre fatores individuais e ambientais. Devido a essas influências, recomenda-se que sejam utilizados modelos explicativos que tomem por base a concepção de que os relacionamentos mudam constantemente em função de alterações nos ambientes em que ocorrem e em mudanças nos indivíduos pertencentes a estas relações (O’Connor, 2010).

Um desses modelos indicados na literatura é o chamado Modelo de Sistemas Contextuais (CSM, na sigla em inglês para Contextual Systems Model), elaborado por Pianta e Walsh (1996). Tal modelo compreende que a qualidade da relação professor-aluno é função dos ambientes escolares (características coletivas das crianças, características da escola, interações entre os indivíduos e características estruturais da sala de aula) e de fatores relacionadas à criança, ao professor e à família. Os estudos de fato sugerem que a qualidade da relação professor-aluno é o resultado de vários fatores presentes nos ambientes escolar e familiar (Hamre et al., 2008).

Neste contexto, de forma compatível com as explicações fornecidas pela Análise do Comportamento anteriormente relatadas, compreende-se que os relacionamentos mudam conforme ocorrem alterações no ambiente. Assim, é esperado que a criança desenvolva relacionamentos de qualidade consistente ao longo do tempo caso seus ambientes se mantenham constantes e que, diferentemente, desenvolva relacionamentos com variadas qualidades quando o seu ambiente de cuidado é modificado (Coleman \& Watson, 2000; O'Connor, 2010; Pianta \& Walsh, 1996; Weinfield, Whaley, \& Egeland, 2004).

Considerando a importância de uma relação professor-aluno positiva em todos os níveis escolares, as mudanças que ocorrem nesse relacionamento ao longo dos anos, e que mesmo mudanças pequenas na qualidade dessa relação podem apresentar implicações relevantes para o desenvolvimento do aluno (O’Connor \& McCartney, 2007), é necessário examinar quais fatores se 
associam a essas modificações (O'Connor, 2010). A identificação dessas variáveis pode auxiliar no delineamento de intervenções que visem a prevenir a queda na qualidade da relação e a ocorrência de relacionamentos negativos, a partir, por exemplo, do desenvolvimento de atitudes mais adequados pelos alunos e de instruções dadas aos professores com vistas a evitar que estabeleçam relações mal adaptativas com os estudantes (Carvalho, 2009; O'Connor, 2010).

A despeito do elevado número de pesquisas sobre a interação entre os professores e seus alunos, poucas são efetuadas em território brasileiro. Dado que o sistema educacional de cada país possui recursos e demandas específicas provenientes de sua cultura, é possível que as características da relação professor-aluno não se generalizem para outras populações (Maulana, Opdenakker, \& Bosker, 2013; Petrucci, Borsa, Barbosa, \& Koller, 2014). Desta forma, compreende-se a importância das pesquisas nacionais acerca do tema.

\subsection{Objetivos}

Neste contexto, o objetivo geral da presente pesquisa é explicitar as variáveis controladoras da rejeição e da aceitação de alunos, relatadas por seus professores, avaliando-se as possíveis diferenças presentes em três anos escolares de níveis distintos de ensino: 1ㅇano do Ensino Fundamental I, 6으 ano do Ensino Fundamental II e 1o ano do Ensino Médio.

Especificamente, o presente estudo visou a:

1. Comparar as frequências com que os alunos de cada sexo são indicados como aceitos ou como rejeitados pelos professores nos três níveis escolares;

2. Comparar as razões alegadas pelos professores ao indicarem os alunos como aceitos ou como rejeitados nos três níveis escolares;

3. Identificar possíveis associações entre as razões para aceitação e para rejeição e o sexo dos alunos indicados. 
Com base nos dados apresentados pela literatura, têm-se as seguintes hipóteses para os respectivos objetivos da presente pesquisa:

1. Sabendo-se que usualmente há diferenças nos comportamentos dos alunos dos dois sexos, sendo que meninos apresentam mais comportamentos disruptivos, e que essas diferenças se acentuam com o passar dos anos, sugere-se que, nos três anos estudados, mais meninos serão rejeitados, quando comparados às meninas, e mais meninas serão aceitas, quando comparadas aos meninos. Ainda, levanta-se a hipótese de que essas diferenças se acentuarão do Ensino Fundamental I para o Ensino Fundamental Il e desse para o Ensino Médio.

2. Tendo em vista as diferenças observadas ao longo dos anos escolares, referentes tanto ao desenvolvimento infantil quanto à abordagem das escolas diante das necessidades dos alunos, as razões pelas quais os professores aceitam ou rejeitam seus alunos apresentarão variações em função do nível escolar em que eles lecionam. As características mais relevantes para os professores julgarem seus alunos no Ensino Fundamental | corresponderão a aspectos comportamentais (tal como comportamentos destrutivos), os quais, com o passar dos níveis, darão lugar a aspectos acadêmicos (tal como desinteresse pelos estudos).

3. Considerando-se a maior frequência com que meninos apresentam padrões externalizantes e meninas exibem padrões internalizantes, acredita-se que meninos serão mais rejeitados por problemas de comportamento externalizantes, ao passo que meninas serão mais rejeitadas por problemas de comportamento internalizantes. Por outro lado, a aceitação se dará a partir de comportamentos adequados que, por serem menos esperados para as crianças de cada sexo, chamarão mais a atenção do professor: enquanto meninos serão aceitos ao serem mais retraídos, as meninas serão mais aceitas ao apresentarem comportamentos mais expansivos. 
Capítulo 4

$\mathrm{O}$ estudo piloto 


\subsection{Fase 1}

Durante o primeiro semestre de 2013, a pesquisadora contatou um total de 30 escolas públicas. Os contatos realizados, bem como seus desfechos, constituíram o estudo piloto da pesquisa, por meio do qual as dificuldades e problemas encontrados possibilitaram melhoras no questionário elaborado pela pesquisadora, bem como no procedimento a ser utilizado para contatar as escolas e para coletar os dados.

Conforme descrito na Figura 2, em 19 das 30 escolas, não foi possível falar com a pessoa que se responsabilizaria por receber a pesquisadora, pois ela estava ausente e/ou era solicitado que fosse feita uma ligação ou enviado um e-mail para contatá-la. Mesmo diante desses procedimentos, não houve retorno dessas escolas. Foi possível conversar via telefone com coordenadores de 11 escolas, dos quais dois mostraram não ter interesse em participar da pesquisa, dois ficaram de conversar com outros superiores ou com os professores, mas não deram resposta mesmo após outras ligações feitas pela pesquisadora, e sete consentiram a participação.

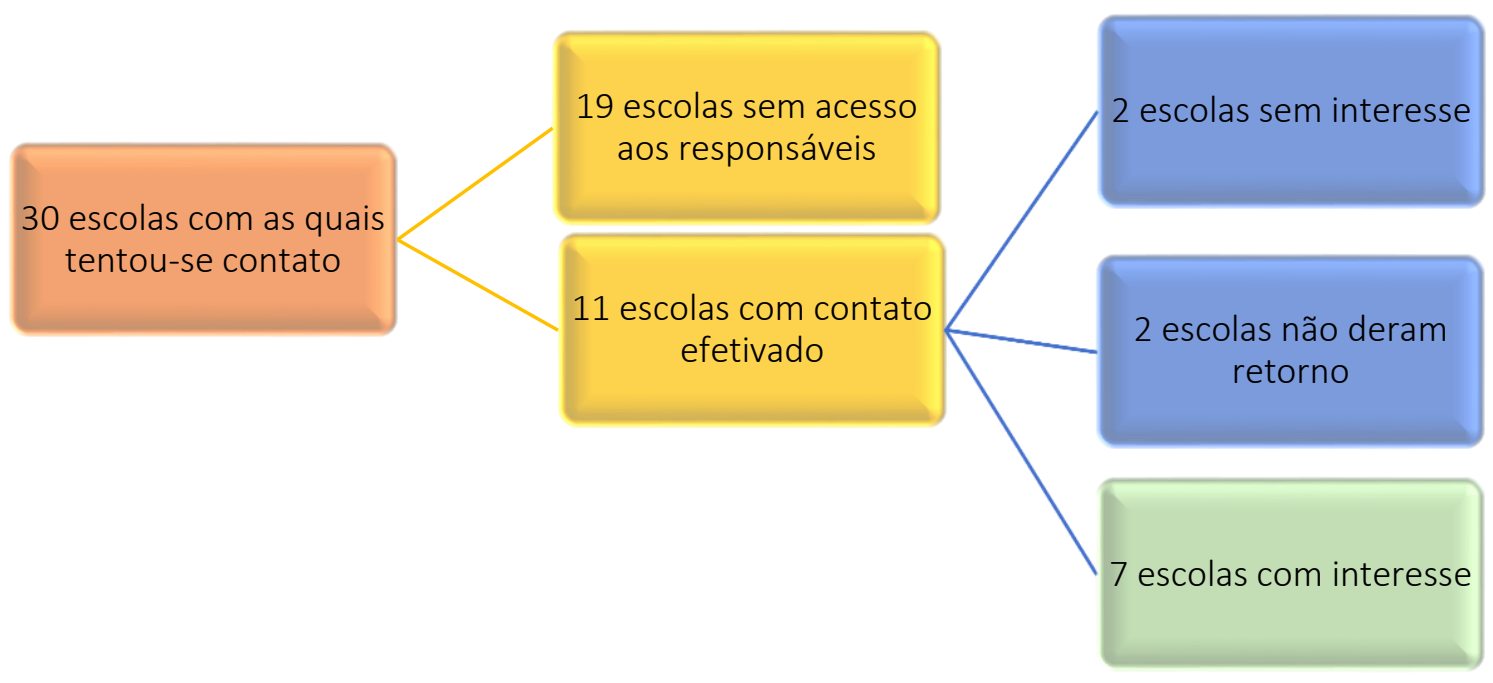

Figura 2. Resultado das tentativas de obtenção de anuência das escolas para participação do estudo piloto da pesquisa. 
Em duas dessas sete escolas, os professores que lecionavam nos anos de interesse para a presente pesquisa não preencheram o questionário, por não estarem presentes no momento da coleta ou por não se interessarem pela participação. Deste modo, conforme indicado na Tabela 1, o estudo piloto foi constituído por 16 professores provenientes de cinco escolas.

Tabela 1:

Distribuição, entre as escolas, do número de professores de cada ano escolar que participou do estudo piloto

\begin{tabular}{cccc}
\hline & \multicolumn{3}{c}{ Número de professores que preencheram o } \\
& questionário \\
\cline { 2 - 4 } Escola & $\begin{array}{r}\text { 1o ano Ensino } \\
\text { Fundamental }\end{array}$ & $\begin{array}{c}\text { 6o ano Ensino } \\
\text { Fundamental }\end{array}$ & $\begin{array}{c}\text { 10 ano } \\
\text { Ensino } \\
\text { Médio }\end{array}$ \\
\hline A & 3 & $*$ & $*$ \\
B & 1 & 0 & $*$ \\
C & 3 & 5 & $*$ \\
D & 0 & 0 & $*$ \\
E & $*$ & 3 & $*$ \\
F & 0 & 0 & $*$ \\
G & 0 & 1 & $*$ \\
\hline Total & 7 & 9 & 0 \\
\hline Ano escolar não contemplado pela escola &
\end{tabular}

* Ano escolar não contemplado pela escola

A seguir serão relatados os procedimentos utilizados, as dificuldades encontradas e as alterações realizadas a partir das coletas nessas sete escolas.

Na coleta realizada na primeira escola, os questionários elaborados inicialmente (APÊNDICE A²) e os Termos de Consentimento Livres e Esclarecidos foram deixados em cima de cada mesa da sala de aula na qual os professores iriam entrar para participar da pesquisa. Após se sentarem às mesas, e com o material já em mãos, os professores foram convidados a ouvir uma breve explicação da pesquisa e algumas orientações para o preenchimento. Observou-se que, quando estas informações iniciais

\footnotetext{
2 Dentre as quatros perguntas elaboradas por Silberman (1969) para identificar diante de quais alunos os professores apresentavam posturas de afeto, rejeição, preocupação e indiferença, foram utilizadas, no questionário inicial da presente pesquisa, as perguntas referentes ao afeto (cujos estudantes indicados foram computados como aceitos) e à rejeição (cujos estudantes indicados foram computados como rejeitados). A escolha destas duas perguntas (as quais buscam identificar para quais alunos o professor gostaria de continuar dando aula e para quais não gostaria de dar aula) se deve à semelhança de seus conteúdos com os das perguntas utilizadas por Coie, Dodge e Coppotelli (1982) e autores posteriores (e.g. Silvares \& Melo, 2010) para identificar quais crianças são rejeitadas ou aceitas pelos seus colegas (perguntas estas que visam a identificar colegas com quem as crianças gostariam de brincar e com quem não gostariam de brincar).
} 
estavam sendo passadas, os participantes estavam distraídos com o material deixado em cima de suas mesas, e não ouviram as orientações da pesquisadora. Durante o preenchimento do questionário, vários dos professores apresentaram dúvidas em relação às perguntas, em especial no que se refere à impossibilidade de pensarem em continuar dando aula para certos alunos no ano seguinte, visto que naturalmente eles passariam para um ano no qual o professor não lecionava. Não apenas isto, mas as trocas de ideias apresentadas pelos professores no momento do preenchimento também se apresentou como um problema na aplicação do instrumento.

Como consequência destas primeiras dificuldades, optou-se pelas seguintes alterações:

1. O questionário e o Termo de Consentimento somente seriam entregues após as orientações da pesquisadora serem passadas.

2. Dentre as orientações, seria solicitado que os professores não trocassem informações entre si, evitando o enviesamento dos dados.

3. A pergunta referente aos alunos aceitos foi substituída por "Suponha que, por algum motivo, você tenha que deixar de dar aula para sua sala e passar a dar aula em outra sala do mesmo ano. Alguns dos alunos da sala antiga serão transferidos para sua nova sala. Se você pudesse escolher três alunos da sala antiga para serem seus alunos na nova turma, quem você escolheria?", de modo a tornar a questão mais compreensível.

4. Similarmente, a pergunta referente aos alunos rejeitados foi substituída por "Suponha que, por algum motivo, você tenha que deixar de dar aula para sua sala e passar a dar aula em outra sala do mesmo ano. Alguns dos alunos da sala antiga serão transferidos para essa nova sala. Se fosse dado a você o direito de escolher três alunos da sala antiga para não serem transferidos, de modo que você não continuaria dando aula para esses três, quem você escolheria?"

Após estas alterações, novas coletas foram realizadas e outras dificuldades se apresentaram. O(A) coordenador(a) ou o(a) diretor(a) das escolas que consentiam a participação na pesquisa convidavam a pesquisadora a aplicar os questionários nos horários em que os professores tinham reuniões, que seria o momento de maior concentração possível de participantes. Com o novo 
questionário, os professores deixaram de manifestar as dúvidas anteriormente apresentadas, mas passaram a questionar em quais alunos deveriam pensar para responder às perguntas, visto que alguns davam aulas a mais de um ano escolar e/ou a mais de uma sala do mesmo ano. Diante disso, a pesquisadora esclarecia verbalmente o que estava sendo solicitado. Ademais, frequentemente afirmavam que não conseguiam pensar em nenhum aluno para o qual não gostariam de dar aula e, quando eram solicitados a pensarem um pouco mais a respeito, raras vezes alteravam sua resposta. Outra questão feita pelos participantes é se precisavam colocar os nomes dos alunos. Uma vez que isso indicava a insegurança dos professores em expor os alunos, a pesquisadora os orientava a colocar nomes fictícios, caso se sentissem mais confortáveis, apenas indicando o sexo do aluno real no qual o professor havia pensado.

Um problema paralelo encontrado foi que, no momento dessas reuniões, raramente havia alguma pessoa que se responsabilizava por controlar a presença e as atividades dos professores e, por consequência, poucos deles de fato estavam presentes ou interessados na pesquisa. Como alternativa, por sugestão de algumas das escolas ou da própria pesquisadora, questionários foram deixados com os coordenadores, para que pudessem ser entregues aos professores que não estavam presentes no horário da coleta. Neste contexto, foram acrescentadas instruções no questionário, tendo em vista as novas dúvidas relatadas pelos professores, ou seja, foi explicitada a informação relativa aos alunos nos quais os participantes deveriam considerar para preencher o instrumento. No entanto, os questionários preenchidos nestas condições muitas vezes estavam incompletos ou havia respostas que poderiam enviesar os dados (tais como "eu abdicaria do direito de deixar de dar aula para determinados alunos").

Tendo em vista as novas dificuldades presenciadas, bem como novas ponderações relativas a estas coletas, foram realizadas as seguintes mudanças no questionário, que possibilitaram o desenvolvimento do questionário definitivo (APÊNDICE B), e nos procedimentos:

1. No questionário, as expressões "fosse dado o direito" e "você pudesse" foram substituídas por "se você tivesse que", de modo a diminuir as chances dos professores considerarem a possibilidade de deixar de fazer o que foi proposto pelas perguntas. 
2. Foram acrescentadas novas perguntas referentes à caracterização do participante: se possui curso superior e qual; se possui especialização e qual; qual disciplina ministra; número de aulas que dá por semana para o ano considerado. Além disso, dadas as dificuldades dos professores em compreender a quais alunos as perguntas se referiam, a pergunta referente ao ano em que o professor leciona foi modificada para:

"Ano em que leciona (caso dê aula para mais de um dos anos abaixo, selecione-os, mas escolha somente um com base no qual responderá o restante do questionário e indique o ano escolhido):

( ) 1 o ano do Ensino Fundamental

( ) 6o ano (ou 5ạ série) do Ensino Fundamental

( ) 1o ano do Ensino Médio

3. Acrescentou-se, por escrito, a informação de que o professor não precisaria colocar o nome dos alunos indicados, caso se sentissem desconfortáveis em relação a isso, devendo somente apresentar o sexo do aluno em questão.

4. Dada a pouca taxa de interesse das escolas contatadas e dos professores, foi realizada uma mudança na apresentação da proposta da pesquisa, visando a um aumento no número de consentimentos: passou-se a oferecer às escolas palestras sobre bullying aos professores, tema este que lhes eram de interesse.

5. Por fim, foi considerada a possibilidade de se solicitar às escolas que permitissem à pesquisadora ficar em suas dependências durante todo um período - e não somente durante o horário da reunião ou que deixasse os questionários com os coordenadores -, para que pudesse passar de sala em sala, fazendo uma aplicação individual do instrumento, de modo a aumentar as chances de mais professores participarem e de haver um preenchimento mais adequado do questionário.

\subsection{Fase 2}

No segundo semestre de 2013, iniciaram-se contatos com novas escolas, cujos dados obtidos foram utilizados como parte da coleta definitiva. A palestra sobre bullying realizada na primeira 
instituição que anuiu a participação na pesquisa se mostrou inicialmente positiva, pois, em função das perguntas e colocações feitas pelos professores, possibilitou que eles conhecessem a pesquisadora, iniciando a formação de vínculo com ela. Ainda assim, os professores dessa escola não aceitaram interromper as aulas por alguns minutos para preencher os questionários, pela impossibilidade de deixar os alunos sozinhos. Deste modo, considerando-se que a última versão do instrumento possuía todas as instruções necessárias para um preenchimento que não necessitasse do auxílio da pesquisadora, optou-se por deixá-lo na escola, para que pudesse ser preenchido pelos participantes no momento em que fosse mais adequado para eles. Tendo em vista o fato de não terem consentido uma participação que envolvesse a interrupção da aula - mesmo que a escola e seus professores tivessem apresentado um vínculo adequado com a pesquisadora - e a necessidade de realizar um procedimento padronizado de coletas de dados, determinou-se que os questionários seriam deixados em todas as escolas participantes, sem que fosse dada uma orientação individual para cada professor, independentemente de sua disponibilidade.

Enquanto a pesquisadora aguardava a autorização da coordenadora de uma escola para que buscasse os questionários preenchidos, foram feitos contatos com sete novas escolas, nas quais as propostas da pesquisa e da palestra eram apresentadas via telefone. Foram vários os desdobramentos que ocorreram com elas: cinco marcaram reuniões para que a proposta fosse apresentada; uma relatou por telefone que não havia interesse; outra, sem que a reunião fosse marcada, solicitou que a pesquisadora aguardasse um retorno sobre a possibilidade de interesse. Esta última manteve esse posicionamento por diversas semanas, mesmo após vários retornos telefônicos da pesquisadora. Das escolas nas quais foi marcada reunião, todas afirmaram ter interesse - em especial por causa da palestra que seria oferecida -, mas que precisavam falar com seus superiores.

Mesmo após diversos contatos telefônicos da pesquisadora, somente uma deu seguimento ao processo, marcando data para a realização da palestra e para a entrega dos questionários. A coordenadora desta escola se mostrou bastante interessada pela pesquisa e exigente com o comprometimento dos professores, sendo possível obter sete questionários de professores de 1음 ano 
do Ensino Fundamental. No entanto, o retorno da primeira escola na qual os questionários foram deixados foi muito inferior até então, a despeito do interesse inicial apresentado pelos professores, com somente três questionários devolvidos. Vale destacar que, após as mudanças relatadas a seguir, esta escola retornou novos questionários preenchidos, os quais puderam ser computados na coleta definitiva.

Após o contato com todas essas escolas e com um total de apenas dez questionários preenchidos, avaliou-se a necessidade de abordar de outra maneira as escolas, dado que o estudo proposto (com um delineamento transversal) necessita de muitos participantes para que tenha dados passíveis de serem analisados adequadamente. Neste contexto, compreendeu-se a importância de estabelecer uma parceria com alguém que apresentasse um papel superior no contexto da escola. Neste sentido, passou-se a buscar um contato direto com os(as) diretores(as) das escolas e com a diretoria de ensino de regiões próximas à cidade de São Paulo. Paralelamente, enquanto tais parcerias não eram consolidadas e enquanto o número total de questionários não era obtido a partir do contato com os diretores de escolas, o procedimento antigo de contato com as escolas foi mantido, com o intuito de se ter maior garantia de que questionários seriam preenchidos. 
Capítulo 5

0 estudo final 


\subsection{Método}

\subsubsection{Participantes}

Participaram da pesquisa 65 professores de 1ㅇano do Ensino Fundamental I, de 60 ano do Ensino Fundamental II e de 1 ㅇano do Ensino Médio, provenientes de sete escolas públicas da cidade de São Paulo e da Grande São Paulo. Como critérios de inclusão e exclusão dos participantes, estabeleceuse que os docentes deveriam lecionar na turma há, pelo menos, dois meses ${ }^{3}$ e que não poderiam estar de licença ou ser professores substitutos. A Figura 3 apresenta a caracterização da amostra, em relação ao ano escolar no qual os participantes lecionam, seus sexos, suas idades, o tempo de profissão, a disciplina que leciona, suas áreas de formação e, se for o caso, de especialização.

\footnotetext{
${ }^{3}$ A decisão em determinar dois meses para inclusão dos professores no estudo se baseou no critério adotado por Achenbach \& Rescorla (2001) para preenchimento do Teacher's Report Form pelo professor. A pesquisadora concorda que este é um tempo considerável para que o professor consiga opinar sobre os alunos de sua classe.
} 


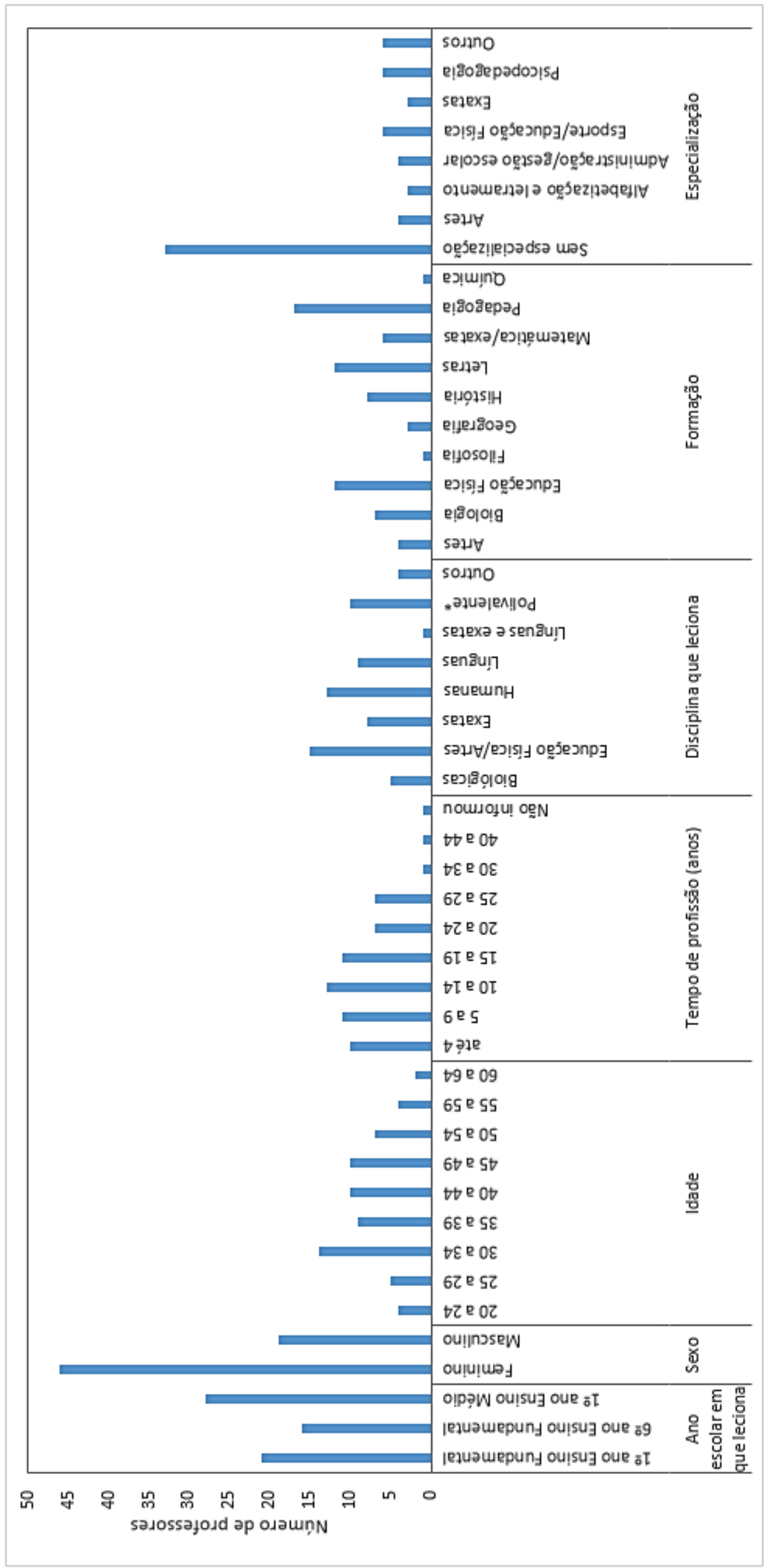




\subsubsection{Instrumento}

Foi utilizado questionário elaborado para os propósitos da presente pesquisa (APÊNDICE B). A primeira parte do instrumento é composta por perguntas voltadas à caracterização da amostra (sexo, idade, tempo de profissão, formação e especialização, ano para o qual leciona). A segunda parte é baseada nas perguntas criadas por Silberman (1969) para identificar diante de quem os professores apresentavam posturas de afeto e de rejeição ${ }^{4}$ e se constitui (1) de perguntas que visam a identificar o sexo dos alunos aceitos e rejeitados pelos professores, podendo haver indicação de qualquer aluno, sendo de inclusão ou não, e (2) de perguntas que têm por objetivo identificar as variáveis controladoras das indicações dos professores, sendo solicitada a explicação das razões primárias e secundárias das indicações de cada aluno. Destaca-se que a pergunta que solicita a descrição das razões primárias foi separada da que solicita as razões secundárias com o intuito de tornar possível a identificação da principal variável controladora das indicações feitas pelos professores e de evitar que outras características vistas pelos professores como positivas ou negativas no aluno fossem descritas como sendo as razões da indicação, mesmo que não o fossem.

\subsubsection{Procedimentos}

Por meio de contatos telefônicos, a pesquisadora se apresentou aos coordenadores ou diretores das escolas e solicitou uma reunião para que os objetivos e procedimentos da pesquisa fossem apresentados. Para que os dados não fossem enviesados, foi dito que o estudo visava a investigar a forma como as características dos alunos interferiam em seu relacionamento com os professores, sem

\footnotetext{
${ }^{4} \mathrm{~A}$ despeito da compreensão de que o termo "postura" se refere a um comportamento como qualquer outro, segundo a concepção da AC apresentada no Capítulo 2, o uso de um termo diferente de "comportamento" visou à especificação da referência à abordagem proposta por Silbermam (1969). Ademais, ainda que as palavras "afeto" e "rejeição" não possibilitem uma compreensão direta dos comportamentos que as incluem, seu uso no presente trabalho teve por objetivo manter-se fiel ao autor, dado que suas categorias foram validadas por autores que as utilizaram ulteriormente. Os comportamentos que caracterizam tais posturas podem ser lidos nas páginas 20 e 21.
} 
que fosse feita qualquer menção às palavras "rejeição" e "aceitação". Quanto aos procedimentos, a pesquisadora informou que somente os professores que assinassem o Termo de Consentimento versão professor (APÊNDICE C) poderiam participar e que os questionários seriam deixados na escola, para que pudessem ser preenchidos pelos educadores no tempo e momento que thes conviessem.

Para que o estudo pudesse ser feito, algumas das escolas aceitaram a proposta da pesquisadora de que fosse realizada em suas dependências, antes da coleta, uma palestra sobre bullying como forma de troca de informações entre os professores e a pesquisadora. Outras escolas, não obstante, solicitaram apenas a devolução dos resultados obtidos após o término da pesquisa.

Foram deixados, em cada escola em que a Direção anuiu a participação na pesquisa, mediante assinatura do Termo de Consentimento - versão para escola (APÊNDICE D), os questionários e os Termos de Consentimento a serem preenchidos pelos professores que se interessassem em participar do estudo. Conforme os professores entregavam aos responsáveis da escola uma das vias dos Termos e os questionários preenchidos, estes eram devolvidos à pesquisadora.

\subsubsection{Análise dos Dados}

As respostas fornecidas pelos participantes, em todo o questionário, foram tabuladas em uma planilha do Excel, de forma a facilitar a visualização e a análise dos dados obtidos.

As razões para aceitação e para rejeição apresentadas pelos professores como sendo as principais foram agrupadas em duas modalidades de categorias: as categorias de aceitação (constituídas a partir das respostas obtidas na pergunta referente à aceitação) e as de rejeição (formadas a partir das respostas obtidas na pergunta referente à rejeição). O procedimento de elaboração das categorias seguiu as seguintes etapas:

1. A pesquisadora elaborou uma primeira versão das categorias (Figura 4) conforme as semelhanças das respostas fornecidas pelos participantes, bem como com base nos dados apresentados pela literatura. As categorias foram elaboradas separadamente para as respostas relativas à rejeição e para as relativas à aceitação; 
2. A partir de discussões com a orientadora, as categorias foram adaptadas (com exclusões ou mudanças em seus nomes e/ou definições) e algumas respostas foram transferidas para categorias diferentes das originais;

3. Foram entregues, a dois juízes independentes (estudantes de mestrado que não possuíam conhecimentos a respeito da literatura referente ao tema da pesquisa e que não haviam participado das discussões entre pesquisadora e orientadora), um documento com as respostas de aceitação e de rejeição por ordem alfabética, em listas diferentes (APÊNDICE E), e um documento constituído por uma tabela com as categorias, suas definições e uma coluna em branco (APÊNDICE F). Os juízes foram solicitados a preencher a coluna em branco com as respostas que julgassem pertencer a cada categoria de aceitação e de rejeição;

4. Com o intuito de evitar manter as categorias que foram atribuídas apenas pela pesquisadora a determinadas respostas, optou-se por discutir com os juízes as respostas nas quais houve concordância entre eles e discordância com a pesquisadora. Tal procedimento teve por objetivo ampliar a consistência conceitual que embasa as categorizações dos dados. A partir destas discussões, determinou-se a manutenção de algumas destas respostas às categorias nas quais foram originalmente colocadas e a realocação de outras; 


\begin{tabular}{|c|c|c|}
\hline \multicolumn{3}{|r|}{ Categorias de aceitação } \\
\hline Nome & Sigla & Definição \\
\hline Auxílio às dificuldades & $A D$ & $\begin{array}{l}\text { o aluno apresenta dificuldades que fazem com que o professor } \\
\text { identifique a necessidade ou o desejo de prestar auxílio a ele }\end{array}$ \\
\hline Engajamento nos estudos & $\mathrm{EE}$ & $\begin{array}{l}\text { o aluno possui características ou se engaja em comportamentos } \\
\text { diretamente favoráveis a sua aprendizagem }\end{array}$ \\
\hline Disciplina & $\mathrm{D}$ & $\begin{array}{l}\text { o aluno se engaja em comportamentos que se adequam às regras } \\
\text { da sala ou escola, facilitando a organização do ambiente e o } \\
\text { andamento da aula }\end{array}$ \\
\hline $\begin{array}{l}\text { Relacionamento interpessoal } \\
\text { positivo }\end{array}$ & $\mathrm{aRI}$ & $\begin{array}{l}\text { o aluno apresenta bom relacionamento com o professor e/ou } \\
\text { colegas ou possui características que possibilitam esse } \\
\text { relacionamento, não estando essa interação associada } \\
\text { diretamente a aspectos acadêmicos }\end{array}$ \\
\hline Colaboração com colegas & $\mathrm{C}$ & $\begin{array}{l}\text { o aluno presta auxílios aos colegas, colaborando diretamente com } \\
\text { o aprendizado dos outros }\end{array}$ \\
\hline Outros & $\mathrm{aO}$ & $\begin{array}{l}\text { respostas que, pela falta de especificações, não puderam ser } \\
\text { incorporadas em nenhuma das categorias ou poderiam ser } \\
\text { inseridas em mais de uma delas }\end{array}$ \\
\hline \multicolumn{3}{|r|}{ Categorias de rejeição } \\
\hline Nome & Sigla & Definição \\
\hline $\begin{array}{l}\text { Atuação de outros } \\
\text { profissionais }\end{array}$ & AP & $\begin{array}{l}\text { o aluno apresenta dificuldades que fazem com que o professor } \\
\text { sinta a necessidade ou o desejo do trabalho de outros } \\
\text { profissionais (outros professores ou profissionais de outras áreas), } \\
\text { por demandar muito tempo ou atenção dele ou pelo fato da } \\
\text { atuação do professor não ser suficiente }\end{array}$ \\
\hline $\begin{array}{l}\text { Falta de engajamento nos } \\
\text { estudos }\end{array}$ & FEE & $\begin{array}{l}\text { o aluno não se engaja em comportamentos favoráveis à } \\
\text { aprendizagem, por falta de interesse, pela ausência de } \\
\text { participação e/ou por ter sua atenção dirigida a eventos não } \\
\text { relacionados aos objetivos acadêmicos das atividades propostas } \\
\text { pelo professor }\end{array}$ \\
\hline Indisciplina & I & $\begin{array}{l}\text { o aluno se engaja em comportamentos incompatíveis com as } \\
\text { regras da sala ou escola, dificultando a organização do ambiente e } \\
\text { o andamento da aula. }\end{array}$ \\
\hline Relacionamento interpessoal & $\mathrm{rRI}$ & $\begin{array}{l}\text { o aluno apresenta relacionamento ruim com o professor e/ou } \\
\text { colegas (que lhes traz consequências negativas) ou possui } \\
\text { características que conduzem a este tipo de relacionamento } \\
\text { interpessoal, tais como desrespeito, má educação e ser um líder } \\
\text { ruim }\end{array}$ \\
\hline Faltas & $\mathrm{F}$ & o aluno está ausente em muitas aulas \\
\hline Outros & $\mathrm{rO}$ & $\begin{array}{l}\text { respostas que, pela falta de especificações, não puderam ser } \\
\text { incorporadas em nenhuma das categorias ou poderiam ser } \\
\text { inseridas em mais de uma delas }\end{array}$ \\
\hline
\end{tabular}

Figura 4. Primeira versão das categorias de aceitação e rejeição 
5. Para avaliar a concordância entre a pesquisadora e os juízes, utilizou-se a estatística Kappa de Fleiss. Quanto às categorias de aceitação, obteve-se um coeficiente Kappa de 0,621, sendo a concordância da pesquisadora com um dos juízes de 0,785 e, com o outro, de 0,621. O coeficiente Kappa para as categorias de rejeição foi de 0,823 , com a concordância da pesquisadora com um dos juízes sendo de 0,852 e, com o outro, de 0,871. Considerando que todos os valores se referem a uma concordância substancial (Landis \& Koch, 1977), determinou-se a manutenção das categorias. A Figura 5 apresenta as categorias definitivas, suas definições e exemplos de respostas correspondentes a cada uma delas.

Cada resposta digitada previamente na planilha do Excel foi substituída pela sua categoria correspondente. Salienta-se que, nos casos de citações de mais de uma razão, por um mesmo professor, para a indicação de um mesmo aluno, houve duas possibilidades: quando as razões alegadas correspondiam a uma mesma categoria, esta categoria foi contabilizada somente uma vez. Quando as razões pertenciam a mais de uma categoria, foi elaborada uma combinação das categorias citadas, a qual, como será apresentado na seção dos resultados, foi contabilizada à parte das categorias que apareceram isoladamente nas respostas.

Em termos das análises estatísticas inferenciais, as comparações entre as variáveis categóricas (categorias de aceitação, categorias de rejeição, sexo do aluno, sexo do professor, área lecionada pelo professor e ano escolar) foram feitas por meio do teste Chi-quadrado de Pearson com correção exata de Monte Carlo. Foi considerado como nível de significância estatística um valor de $p \leq 0,05$ e como sendo marginalmente significativo quando $0,05<p \leq 0,1$. Comparações múltiplas foram corrigidas por meio das correções de Bonferroni. 


\begin{tabular}{|c|c|c|c|}
\hline \multicolumn{4}{|c|}{ Categorias de Aceitação } \\
\hline Nome & Sigla & Definição & Exemplos \\
\hline Presença de dificuldades & PDi & $\begin{array}{l}\text { o aluno apresenta ou apresentava dificuldades, } \\
\text { podendo ser explicitado que estas fazem com } \\
\text { que o professor queira prestar auxílio a ele e/ou } \\
\text { identifique a necessidade de fazer isso }\end{array}$ & $\begin{array}{l}\text { Aluno com dificuldades; } \\
\text { Dificuldade de aprendizagem; } \\
\text { Aluna necessita de atenção } \\
\text { pois mimada }\end{array}$ \\
\hline Engajamento nos estudos & $\mathrm{EE}$ & $\begin{array}{l}\text { o aluno possui características ou se engaja em } \\
\text { comportamentos diretamente favoráveis a sua } \\
\text { aprendizagem }\end{array}$ & $\begin{array}{l}\text { Adora ler; Aluno alfabetizada; } \\
\text { Bom envolvimento nas aulas; } \\
\text { Curiosidade; Empenhado; } \\
\text { Participativa; Vontade de } \\
\text { aprender }\end{array}$ \\
\hline Disciplina & $\mathrm{D}$ & $\begin{array}{l}\text { o aluno possui características ou se engaja em } \\
\text { comportamentos que se adequam às regras } \\
\text { implícitas ou explícitas da sala ou escola - } \\
\text { voltados a outros alunos, aos colegas e/ou ao } \\
\text { professor -, facilitando a organização do } \\
\text { ambiente e o andamento da aula }\end{array}$ & $\begin{array}{l}\text { Bom comportamento; Aluna } \\
\text { prestativa; Bastante sociável; } \\
\text { Colaborativa com os demais; } \\
\text { Liderança positiva; Respeito } \\
\text { pelo professor e pelos colegas } \\
\text { e pela escola }\end{array}$ \\
\hline Outros & $\mathrm{aO}$ & $\begin{array}{l}\text { respostas que, pela falta de especificações, não } \\
\text { puderam ser incorporadas em nenhuma das } \\
\text { categorias ou poderiam ser inseridas em mais de } \\
\text { uma delas }\end{array}$ & $\begin{array}{l}\text { Aprender a conviver e interagir; } \\
\text { Disciplina; Afinidade }\end{array}$ \\
\hline \multicolumn{4}{|c|}{ Categorias de Rejeição } \\
\hline Nome & Sigla & Definição & Exemplos \\
\hline Presença de déficits & PDe & $\begin{array}{l}\text { o aluno apresenta déficits de pré-requisitos para } \\
\text { o aprendizado, podendo demandar muito tempo } \\
\text { ou atenção do professor ou tornar sua atuação } \\
\text { insuficiente, fazendo com que o professor queira } \\
\text { ou ache necessária a atuação de outros } \\
\text { profissionais, sejam professores com a mesma } \\
\text { função que o participante ou profissionais de } \\
\text { outras áreas. }\end{array}$ & $\begin{array}{l}\text { Aluna que precisa de trabalho } \\
\text { diferenciado, envolvendo } \\
\text { outras especialidades também } \\
\text { e claro principalmente da } \\
\text { família; É a criança que mais } \\
\text { preenche o dia, é bastante } \\
\text { comunicativo, porém } \\
\text { desorganizado. Necessita de } \\
\text { orientação constantemente. Já } \\
\text { foi solicitado aos pais uma } \\
\text { avaliação psicopedagógica; Não } \\
\text { alfabetizado }\end{array}$ \\
\hline $\begin{array}{l}\text { Falta de engajamento nos } \\
\text { estudos }\end{array}$ & FEE & $\begin{array}{l}\text { o aluno possui características ou se engaja em } \\
\text { comportamentos desfavoráveis à aprendizagem, } \\
\text { por falta de interesse, pela ausência de } \\
\text { participação e/ou por ter sua atenção dirigida a } \\
\text { eventos não relacionados aos objetivos } \\
\text { acadêmicos das atividades propostas pelo } \\
\text { professor }\end{array}$ & $\begin{array}{l}\text { Aluna que faz questão de não } \\
\text { progredir; Aluno pouco } \\
\text { participativo; Desinteressado; } \\
\text { Dificuldade de concentração; } \\
\text { Falta de compromisso; Sem } \\
\text { vontade de aprender }\end{array}$ \\
\hline Indisciplina & । & $\begin{array}{l}\text { o aluno possui características ou se engaja em } \\
\text { comportamentos incompatíveis com as regras } \\
\text { implícitas ou explícitas da sala ou escola - } \\
\text { voltados a outras pessoas ou a objetos -, } \\
\text { dificultando a organização do ambiente e o } \\
\text { andamento da aula }\end{array}$ & $\begin{array}{l}\text { Dificuldade de aceitar regras; } \\
\text { Indisciplinada; Agressivo; } \\
\text { Arrogância; Atrapalha os } \\
\text { colegas; Líder negativo }\end{array}$ \\
\hline Outros & $\mathrm{rO}$ & $\begin{array}{l}\text { respostas que, pela falta de especificações ou } \\
\text { por serem discrepantes das outras categorias, } \\
\text { não puderam ser incorporadas em nenhuma das } \\
\text { categorias ou poderiam ser inseridas em mais de } \\
\text { uma delas }\end{array}$ & $\begin{array}{l}\text { Aluno com comportamento } \\
\text { apático, não responde a } \\
\text { comandos; Aprendizagem; } \\
\text { Ansioso; Demora para realizar } \\
\text { as atividades; Excesso de faltas; } \\
\text { Esconde-se atrás de sua } \\
\text { deficiência; Respaldo da } \\
\text { conduta }\end{array}$ \\
\hline
\end{tabular}

Figura 5. Categorias de aceitação e de rejeição, elaboradas com base no agrupamento das razões alegadas pelos professores para a indicação de cada aluno. 


\subsubsection{Aspectos éticos}

A presente pesquisa foi aprovada pelo Comitê de Ética em Pesquisa com Seres Humanos do Instituto de Psicologia da Universidade de São Paulo (CAAE: 12682113.0.0000.5561). Somente mediante a assinatura dos Termos de Consentimento Livres e Esclarecidos (APÊNDICES C e D) - conforme a Resolução Normativa 196, de 10 de outubro de 1996, do Ministério da Saúde -, os envolvidos puderam participar da pesquisa. Além disso, o participante pôde se recusar a participar do estudo ou retirar seu consentimento a qualquer momento, sem penalização ou prejuízo. A pesquisadora se disponibilizou para esclarecer quaisquer dúvidas acerca do estudo e se prontificou para atender individualmente e em caráter sigiloso os professores que se sentissem desconfortáveis ao manifestar suas opiniões sobre seus alunos. 


\subsection{Resultados e discussão}

Nesta seção, os subitens apresentam os resultados e a discussão correspondentes a cada um dos três objetivos iniciais da pesquisa. A depender dos resultados indicados, foram realizadas, no próprio subitem, algumas análises complementares relacionadas ao objetivo principal do tópico, tomando por base fatores que possam ter influenciado os dados obtidos.

\subsubsection{Sexo do aluno versus ano escolar}

\section{Resultados}

A Tabela 2 e a Figura 6 possibilitam visualizar os dados relativos ao sexo das crianças indicadas nos três anos estudados. A Tabela 2 apresenta o número absoluto de indicações de estudantes de cada sexo nas perguntas relativas à aceitação e à rejeição. Vale destacar que, pelo fato de haver professores que não indicaram as três crianças solicitadas em cada pergunta, não foram obtidos os mesmos totais de indicações de crianças aceitas e rejeitadas em cada ano escolar. A Figura 6, por sua vez, indica as proporções, em relação ao número total de indicações realizadas pelos professores de cada ano, de meninas e meninos aceitos e rejeitados.

Tabela 2.

Número de indicações de alunas e alunos nas perguntas relativas à aceitação e à rejeição, nos três anos escolares

\begin{tabular}{|c|c|c|c|c|c|c|}
\hline \multirow{2}{*}{$\begin{array}{c}\text { Número } \\
\text { de } \\
\text { indicações }\end{array}$} & \multicolumn{2}{|c|}{$\begin{array}{l}\text { 10 ano Ensino } \\
\text { Fundamental }\end{array}$} & \multicolumn{2}{|c|}{$\begin{array}{l}60 \text { ano Ensino } \\
\text { Fundamental }\end{array}$} & \multicolumn{2}{|c|}{10 ano Ensino Médio } \\
\hline & Aceitos & Rejeitados & Aceitos & Rejeitados & Aceitos & Rejeitados \\
\hline Alunos & 29 & 46 & 20 & 43 & 39 & 57 \\
\hline Alunas & 33 & 8 & 28 & 4 & 45 & 26 \\
\hline Total & 62 & 54 & 48 & 47 & 84 & 83 \\
\hline
\end{tabular}




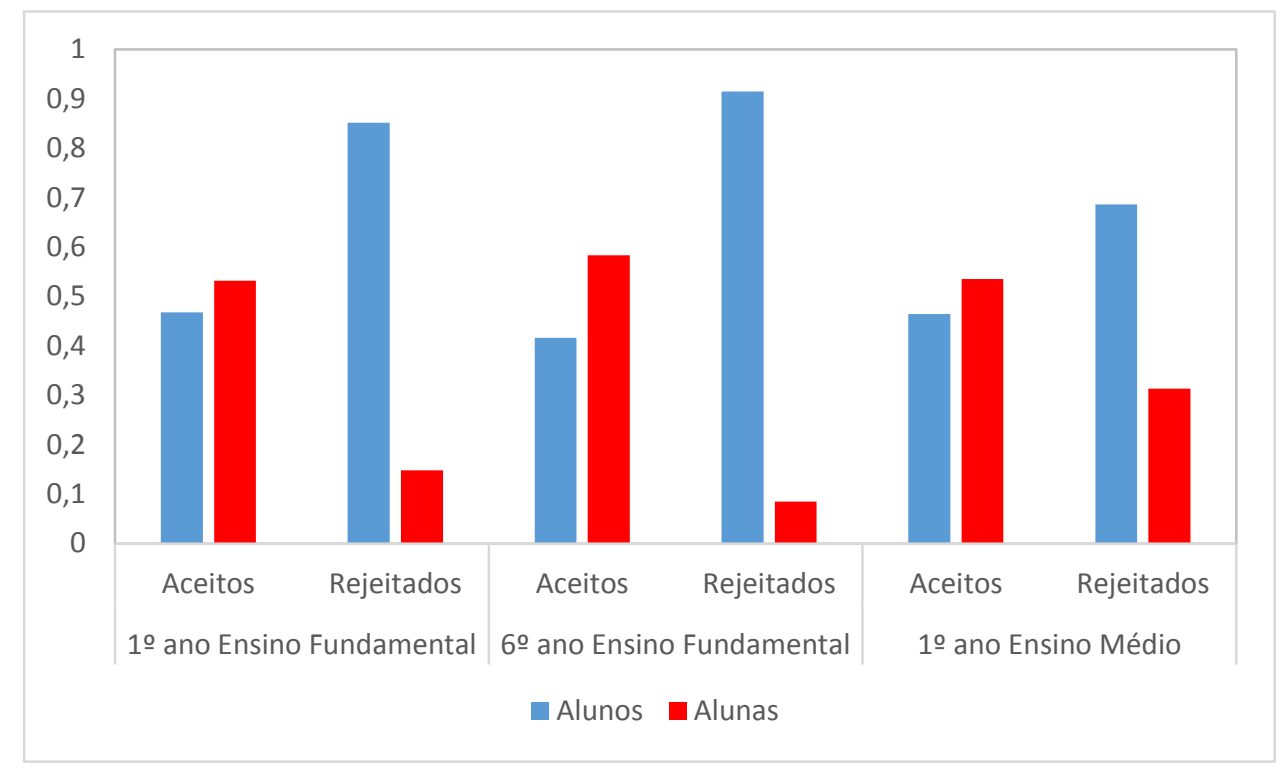

Figura 6. Proporções, em relação ao total de estudantes aceitos ou rejeitados em cada ano, de indicações de alunas e alunos nos três níveis escolares.

A partir da Tabela 2 e da Figura 6, observa-se que os professores rejeitaram mais meninos do que meninas nos três níveis escolares investigados, sendo que esta diferença foi maior no 60 ano do Ensino Fundamental e menor no 1ํano do Ensino Médio. A análise inferencial indicou uma variação estatisticamente significativa do sexo do aluno rejeitado conforme o ano escolar ( $p$-valor=0,003).

No que se refere à aceitação, nota-se um maior número de indicações de meninas do que de meninos, mas estas diferenças foram consideravelmente menores que as diferenças nas de rejeição nos três anos escolares. A análise inferencial indicou não haver uma variação estatisticamente significativa do sexo do aluno aceito conforme o ano escolar ( $p$-valor=0,869).

\section{Discussão}

Os resultados relativos à rejeição são coerentes com os vários dados apresentados pela literatura internacional e com os poucos da literatura brasileira, que apontam haver uma relação mais conflituosa e menos próxima com os estudantes do sexo masculino e uma interação de maior afinidade com os estudantes do sexo feminino (Baker, 2006; Barbosa et al., 2011; Birch \& Ladd, 1997; BolsoniSilva et al., 2013; Jerome et al., 2008; Kesner, 2000; Rudasill \& Rimm-Kaufman, 2009; Silver et al., 2005). 
Levanta-se a possibilidade de que estas diferenças se devam aos comportamentos diferenciados comumente encontrados nas crianças de cada sexo, sendo que os meninos apresentam mais atitudes que podem perturbar o andamento da aula, sendo, por exemplo, mais hiperativos e desobedientes que as meninas, as quais se mostram mais atentas e mais sensíveis a mudanças no ambiente (Gardinal \& Marturano, 2007; Kwok et al., 2007; LaFrance et al., 2003; Maia et al., 2011; Mendez et al., 2002; Stuhlman \& Pianta, 2002; Zhou et al., 2009). Considerando o que é apontado pela literatura, referente ao fato de que as diferenças entre os comportamentos dos meninos e das meninas aumentam com o passar dos anos (Else-Quest et al., 2006; Sanson et al., 1994), pode-se explicar a partir deste fenômeno a maior diferença encontrada, na presente pesquisa, entre os sexos dos alunos rejeitados pelos professores de 60 ano, quando comparados aos dos alunos rejeitados pelos de 1 음 ano do Ensino Fundamental. No entanto, a menor diferença encontrada entre as alunas e os alunos rejeitados do Ensino Médio vai de encontro a esta ideia.

Os dados relativos à aceitação, por sua vez, foram menos expressivos do que os esperados diante da hipótese de que haveria crianças do sexo feminino aceitas com maior frequência que crianças do sexo masculino. Considerando que a literatura internacional aponta não apenas que o relacionamento dos professores com os meninos é de pior qualidade, como também que as interações com as meninas são marcadas por mais afinidade e menos conflito (e.g. Baker, 2006; Barbosa et al., 2011; Jerome et al., 2008), entende-se que seriam esperadas diferenças maiores entre a aceitação de meninas e de meninos. Analogamente ao que foi observado em relação aos alunos rejeitados, o aumento dessas diferenças do $1^{\circ}$ ano do Ensino Fundamental para o 6으 ano é coerente com o que é apontado por Jerome et al. (2008) referente ao fato da proximidade com meninas ser cada vez maior que a proximidade com meninos. Entretanto, a queda na diferença entre os alunos do Ensino Médio abre espaço para a hipótese de, neste nível de ensino, haver maior valorização dos estudos, sendo possível que a frequência de comportamentos indicativos de engajamento nos estudos se torne mais próxima entre meninas e meninos mais velhos. 


\section{Outros fatores}

Considerando os dados da literatura referentes ao fato de que o sexo do professor pode influenciar suas posturas diante dos alunos, de forma que o relacionamento com estudantes do mesmo sexo que o docente é de melhor qualidade que o relacionamento com estudantes do sexo oposto (Dee, 2005, 2007; Mullola et al., 2012), optou-se por analisar a possibilidade deste fator ter relação com os resultados expostos acima, embora extrapole os objetivos do presente estudo. Deste modo, a Figura 7 apresenta as proporções de indicações de meninas e meninos feitas pelos professores e pelas professoras na resposta à pergunta sobre aceitação, em relação ao total de estudantes citados pelos docentes de cada sexo ${ }^{5}$.

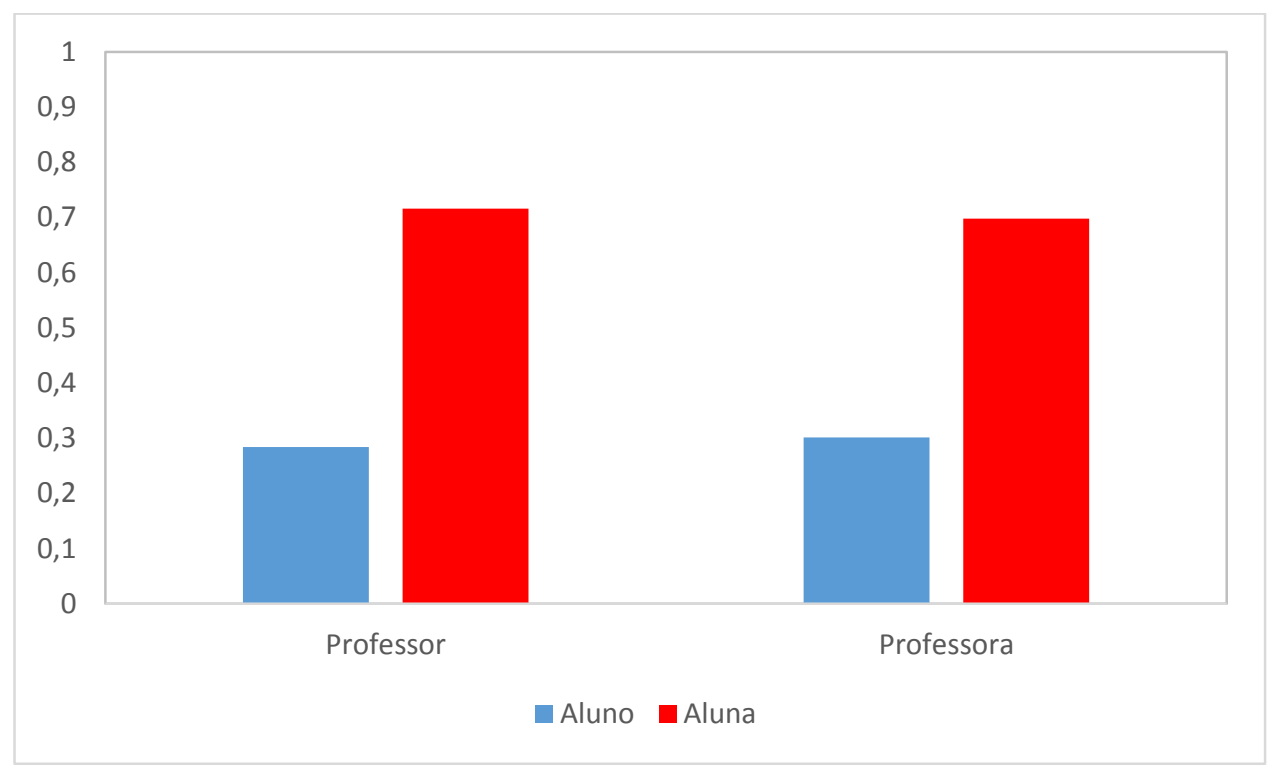

Figura 7. Proporções de indicações de meninas e meninos aceitos feitas pelos professores de cada sexo.

A partir da Figura 7, nota-se que as diferenças nas proporções de indicações de meninos e de meninas foram semelhantes entre os professores e as professoras, sendo que ambos nomearam mais meninas na resposta relativa à aceitação. A análise inferencial indicou que não houve diferença estatisticamente significativa entre as proporções de indicações de meninos e meninas por parte dos professores e as proporções de indicações feitas pelas professoras ( $p$-valor=0,875).

${ }^{5}$ Os dados brutos relativos às análises apresentadas desta seção em diante podem ser consultados no APÊNDICE G. 
A Figura 8 apresenta as proporções de indicações de meninas e meninos feitas pelos professores e pelas professoras na resposta à pergunta sobre rejeição, em relação ao total de estudantes citados pelos docentes de cada sexo.

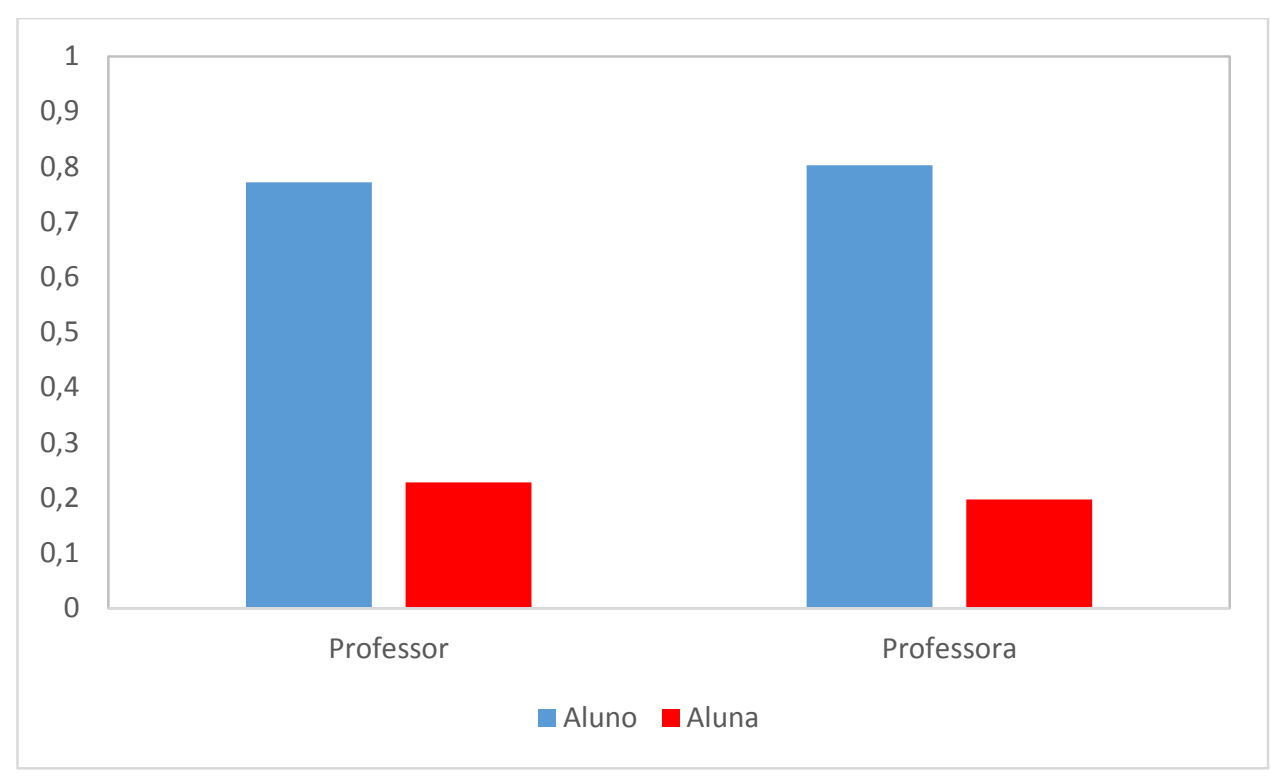

Figura 8. Proporções de indicações de meninas e meninos rejeitados feitas pelos professores de cada sexo.

A partir da Figura 8, observa-se que as diferenças nas proporções de indicações de meninos e de meninas foram semelhantes entre os professores e as professoras, sendo que ambos nomearam mais meninos na resposta relativa à rejeição. A análise inferencial indicou que não houve diferença estatisticamente significativa entre as proporções de indicações de meninos e meninas por parte dos professores e as proporções de indicações feitas pelas professoras ( $p$-valor=0,697).

Além da análise do sexo dos docentes, efetuou-se uma análise inferencial dos dados referentes à relação entre o sexo dos alunos indicados e a disciplina lecionada pelos professores. Para isso, com o objetivo de possibilitar uma análise mais acurada dos dados, as áreas em que os docentes lecionam foram agrupadas em quatro categorias que apresentam demandas curriculares diferenciadas, a saber, Grupo A (composta por Biológicas, Exatas e Línguas), Grupo B (constituída por Educação Física e Artes), Outros e Polivalente (estas duas últimas mantidas conforme a classificação feita previamente e apresentada na caracterização da amostra). 
A Figura 9 apresenta as proporções de indicações de meninas e meninos aceitos feitas pelos professores de cada área, em relação ao total de indicações de estudantes de cada sexo.

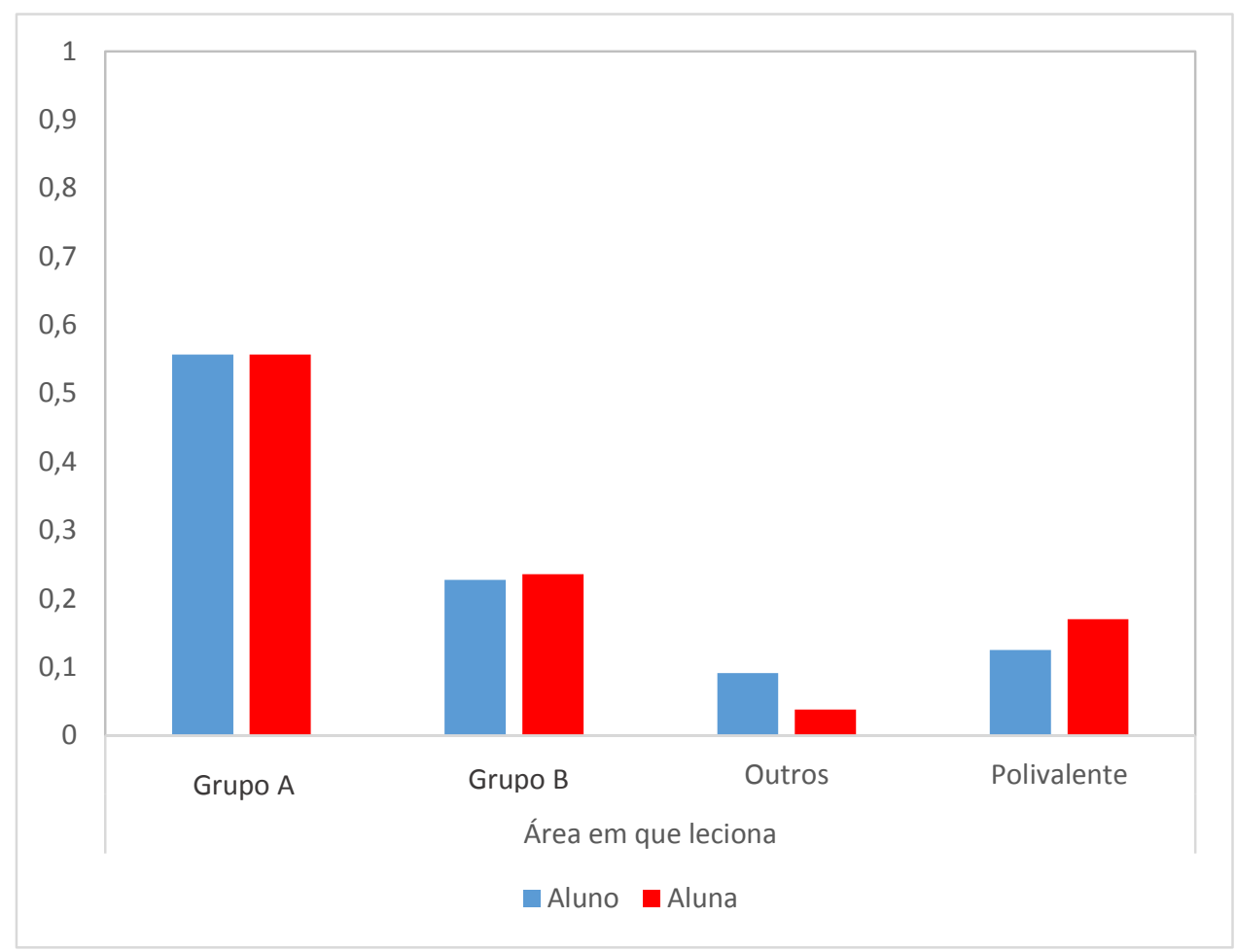

Figura 9. Proporções de indicações de meninas e meninos aceitos feitas pelos professores que lecionam em cada área.

A partir da Figura 9, nota-se que as diferenças nas proporções de indicações de meninas e de meninos aceitos foram semelhantes entre os professores de cada área. Ainda que a proporção de meninos indicados pelos professores da área "Outros" tenha sido maior que a de meninas e que a proporção de meninos indicadas por professores polivalentes tenha sido menor que a de meninas, a análise inferencial indicou que estas diferenças não foram estatisticamente significativas ( $p$ valor $=0,547)$.

A Figura 10, por sua vez, apresenta as proporções de indicações de meninas e meninos rejeitados feitas pelos professores que lecionam em cada área, em relação ao total de indicações de estudantes de cada sexo. 


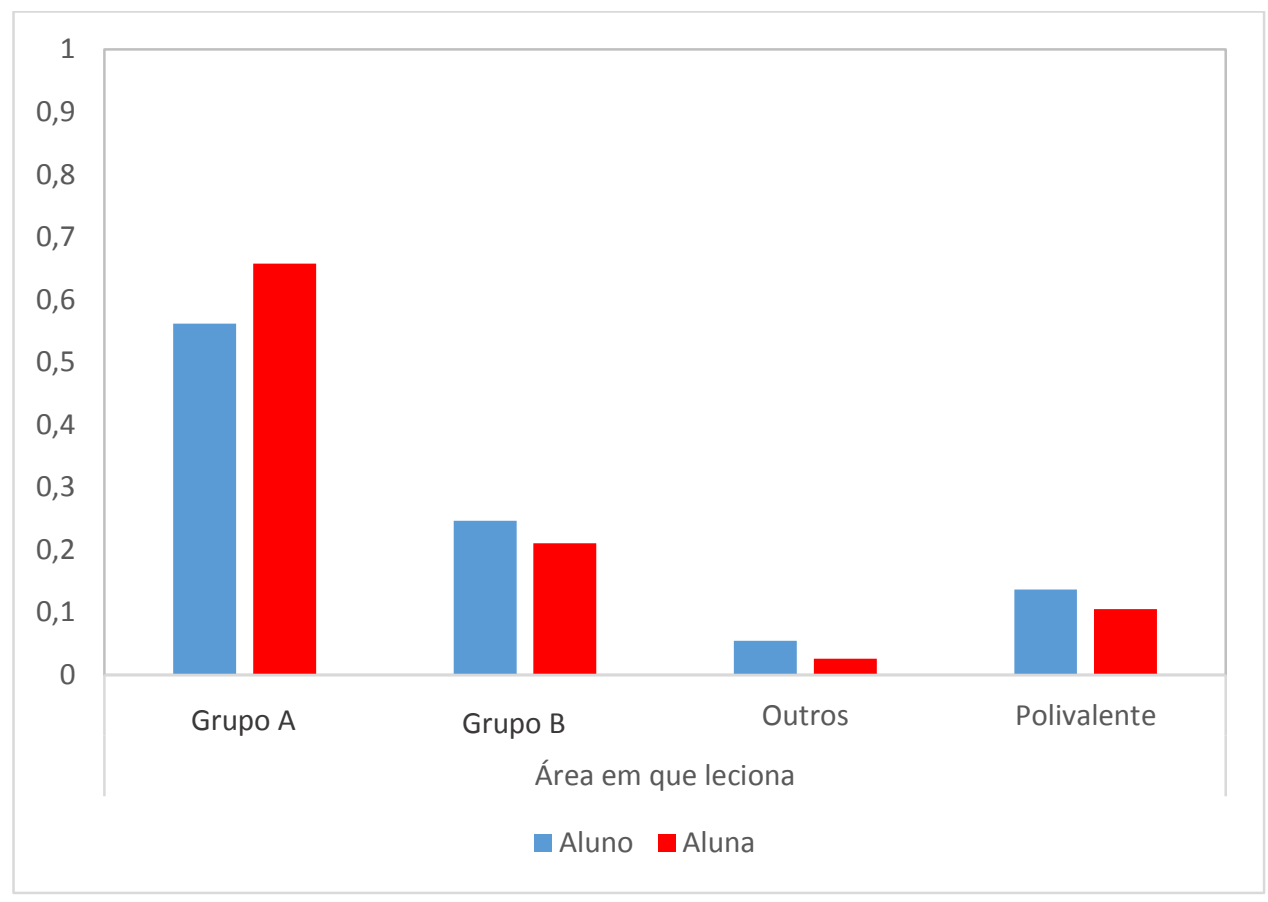

Figura 10. Proporções de indicações de meninas e meninos rejeitados feitas pelos professores que lecionam em cada área.

A Figura 10 indica que as diferenças nas proporções de nomeações de meninas e de meninos rejeitados foram semelhantes entre os professores de cada área. A maior diferença se apresenta no caso dos professores do Grupo A, com a proporção de meninas indicadas sendo maior do que a de meninos. No entanto, não houve diferença estatisticamente significativa nas distribuições das proporções de meninos e de meninas indicados pelos educadores de cada área ( $p$-valor=0,716).

Sugere-se, a partir das relações apresentadas acima, que os padrões encontrados relativos às proporções de meninas e meninos indicados nas perguntas referentes à aceitação e à rejeição não são fruto das diferenças nas áreas de ensino dos professores ou do maior número de docentes do sexo feminino que constituíram a amostra do presente estudo.

\subsubsection{Razões para as indicações versus ano escolar}

\section{Resultados}

Quanto às relações entre as categorias mencionadas pelos professores e o ano escolar em que lecionam, a Figura 11 apresenta uma comparação das proporções de menções das categorias de aceitação em relação aos totais de citações em cada ano. Neste cálculo, contabilizou-se o número total 
de citações das categorias, independentemente de terem sido mencionadas isoladamente ou em conjunto com outras categorias.

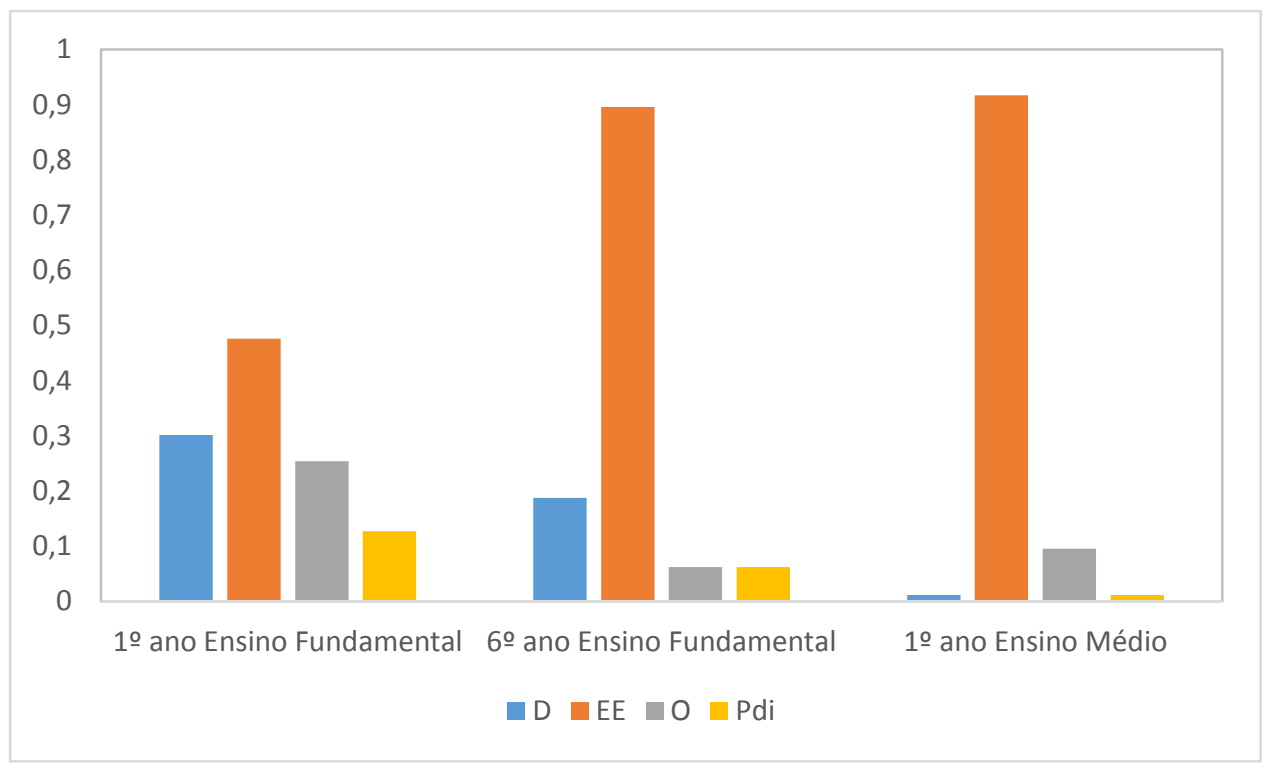

Figura 11. Proporções totais de citações de cada categoria de aceitação, contabilizadas independentemente de sua menção isolada ou em conjunto com outras categorias, relativas ao total de citações em cada ano. D=Disciplina; EE=Engajamento nos Estudos; $\mathrm{O}=$ Outros; Pdi=Presença de Dificuldades.

A partir da Figura 11, observa-se uma redução na proporção de citações da categoria

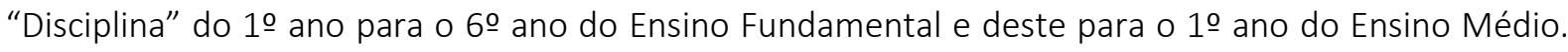
Ainda que a diferença do 1ㅇa ano do Ensino Fundamental para o 6으 ano não tenha sido estatisticamente significativa ( $p$-valor=0,192), ela foi estatisticamente significativa do 1 o ano e do 60 ano do Ensino Fundamental para o 1 o ano do Ensino Médio (em ambas, p-valor<0,016).

A proporção de citações de "Engajamento nos Estudos", por sua vez, apresentou um aumento do 10 para o 60 ano do Ensino Fundamental e manteve-se constante na passagem para o 1 을 ano do Ensino Médio. Com exceção da diferença entre o 6o ano do Ensino Fundamental e o 1o ano do Ensino Médio ( $p$-valor=0,760), as variações entre os anos do Ensino Fundamental e entre o 6을 ano e o 1 을 ano do Ensino Médio foram estatisticamente significativas (em ambas, p-valor<0,016). 
Quanto à categoria "Outros", verifica-se uma redução em sua frequência na passagem do 1으 para o 60 ano do Ensino Fundamental e um pequeno aumento entre este e o Ensino Médio, sendo estatisticamente significativas apenas as diferenças entre os anos do Ensino Fundamental (em ambas, p-valor<0,016).

Nota-se, por fim, que "Presença de Dificuldades" apresentou uma redução de menções com o passar dos anos avaliados, ainda que desde o início se apresentasse em proporção reduzida. A diferença entre $\circ 1^{\text {o }}$ ano e o 6 o ano do Ensino Fundamental foi estatisticamente significativa ( $p$-valor $\left.<0,016\right)$, ao passo que a diferença entre este ano e o 1 ํano do Ensino Médio não alcançou significância estatística ( $p$-valor=0,352).

Na Figura 12, são consideradas separadamente as categorias mencionadas sozinhas e as citadas juntamente com outras, comparando-se as proporções de citações das categorias relativas aos totais de citações realizadas em cada ano escolar estudado.

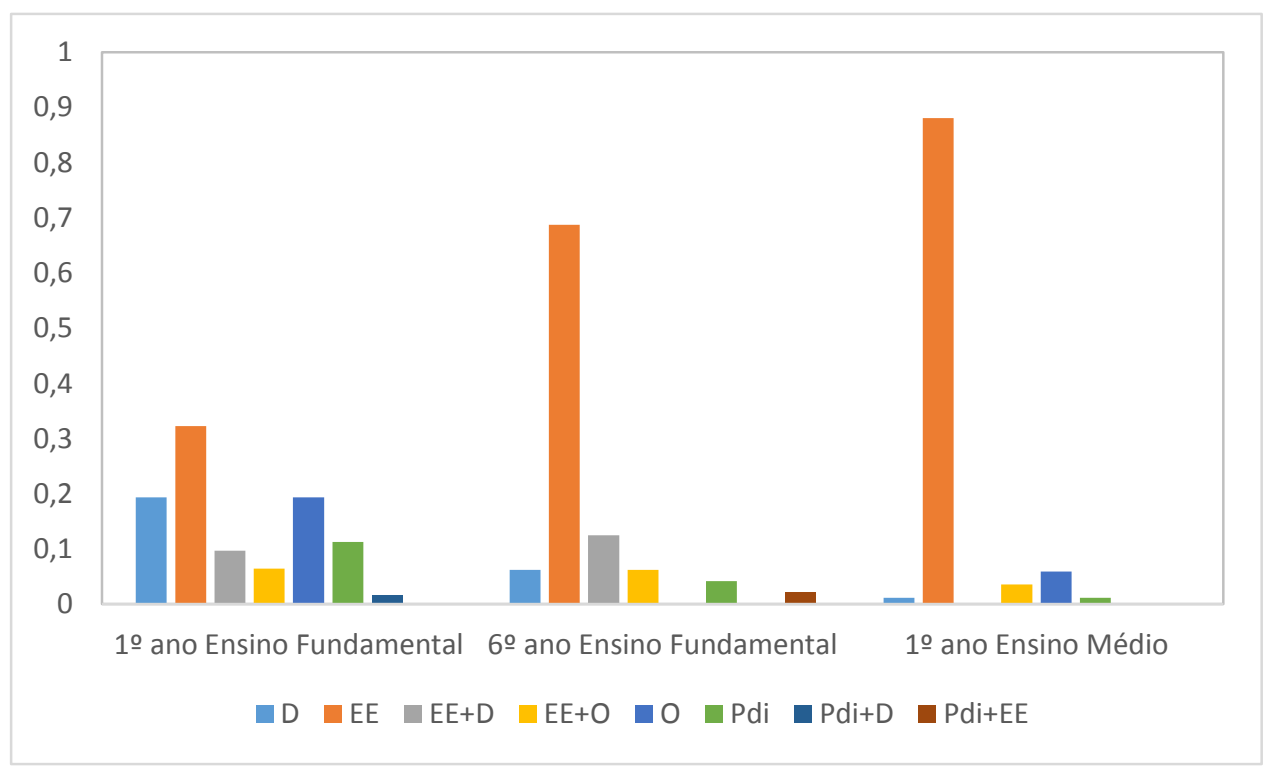

Figura 12. Proporções de citações das categorias de aceitação, citadas isoladamente ou em conjunto com outras, relativas ao total de citações das categorias em cada ano. D=Disciplina; EE=Engajamento nos Estudos; O=Outros; Pdi=Presença de Dificuldades.

A partir da Figura 12, verifica-se que, nos três anos escolares, a categoria mais mencionada isoladamente pelos professores é a "Engajamento nos Estudos", sendo que a proporção de citações 
desta categoria aumenta com o passar dos anos estudados. Observa-se, no $1^{\text {o }}$ ano do Ensino Fundamental, uma distribuição mais uniforme das proporções de citações das diferentes categorias, com "Disciplina" e "Outros" sendo mencionadas isoladamente em segundo lugar e, em terceiro, "Presença de Dificuldades". No 6o ano do Ensino Fundamental e no 1o ano do Ensino Médio, a distribuição das proporções foi expressivamente menos uniforme, com "Engajamento nos Estudos" sendo substancialmente mais mencionado como razão para aceitação.

Em relação às categorias mencionadas em conjunto, destaca-se que "Engajamento nos Estudos" e "Disciplina" foram indicadas juntamente apenas nos dois primeiros anos, ainda que a proporção de sua citação conjunta se apresente menor, no primeiro ano, quando comparado a cada uma dessas categorias mencionadas isoladamente, e expressivamente menor que "Engajamento nos Estudos", no segundo ano avaliado. "Presença de Dificuldades" foi citado em conjunto com "Disciplina" apenas uma vez no 1 ํaㅇ ano do Ensino Fundamental e, com "Engajamento nos Estudos", uma vez no 6응 ano. "Engajamento nos Estudos" e "Outros" foram mencionadas em conjunto em todos os anos, mas também com uma frequência baixa.

A análise inferencial indicou uma diferença estatisticamente significativa na distribuição do número de citações de cada categoria de aceitação entre os três anos escolares ( $p$-valor=0,000).

A Figura 13 apresenta uma comparação entre as proporções de menções das categorias de rejeição em relação aos totais de citações em cada ano. Nesta análise, contabilizou-se o número total de citações das categorias, independentemente de terem sido mencionadas isoladamente ou em conjunto com outras categorias. 


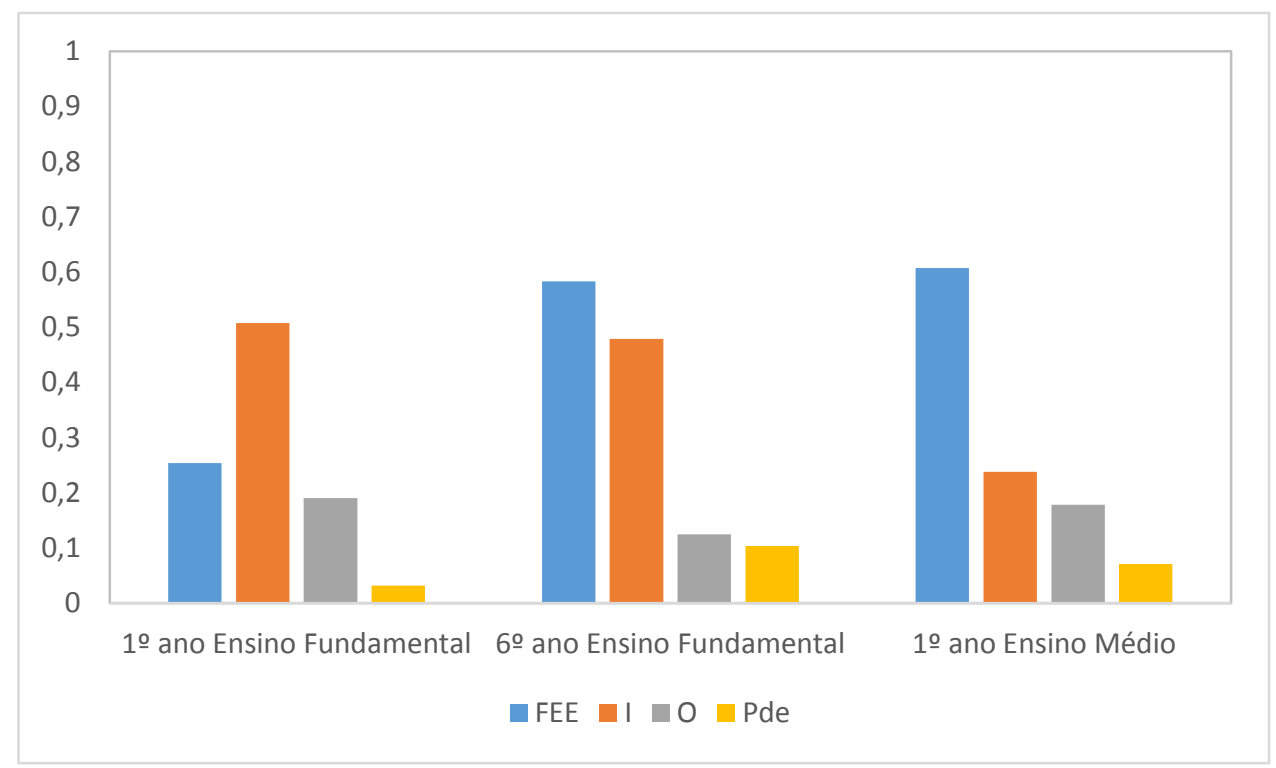

Figura 13. Proporções totais de citações de cada categoria de rejeição, contabilizadas independentemente de sua menção isolada ou em conjunto com outras categorias, relativas ao total de citações em cada ano. FEE=Falta de Engajamento nos Estudos; I=Indisciplina; O=Outros; Pde=Presença de Déficits.

Pela Figura 13, nota-se que a frequência de citações de "Falta de Engajamento nos Estudos" apresentou um aumento do $1^{\circ}$ ano para o 60 ano do Ensino Fundamental, mantendo-se constante na passagem para o 1ㅇano do Ensino Médio. A análise inferencial indicou que o aumento ocorrido entre o 1 을 ano e o 60 ano do Ensino Fundamental foi estatisticamente significativo ( $p$-valor $<0,016$ ), bem como o aumento do 1ㅇa ano do Ensino Fundamental para o Ensino Médio ( $p$-valor<0,016). A diferença entre o 6ㅇa ano e o 1 ํano do Ensino Médio não foi significativa ( $p$-valor=0,853).

Em relação à categoria "Indisciplina", por outro lado, observou-se uma redução na frequência de suas citações do 1ำ para o 6으 ano do Ensino Fundamental, seguida de uma redução mais expressiva na passagem para o Ensino Médio. Porém, a diferença observada entre os dois anos estudados do Ensino Fundamental não alcançou significância estatística ( $p$-valor=0,840), ao passo que as diferenças entre os anos do Ensino Fundamental e o Ensino Médio foram estatisticamente significativas (em ambas, p-valor<0,016).

Quanto às categorias "Outros" e "Presença de Déficits", mencionadas em menor proporção que as anteriores, ainda que o gráfico apresente uma variação entre os anos escolares, as diferenças nas 
distribuições das proporções de citações entre os anos indicadas não foram estatisticamente significativas (respectivamente, $p$-valor $=0,662 ; p$-valor $=0,334$ ).

Na Figura 14, são consideradas separadamente as categorias mencionadas sozinhas e as citadas juntamente com outras, comparando-se as proporções de citações das categorias de rejeição relativas aos totais de citações realizadas em cada ano escolar estudado.

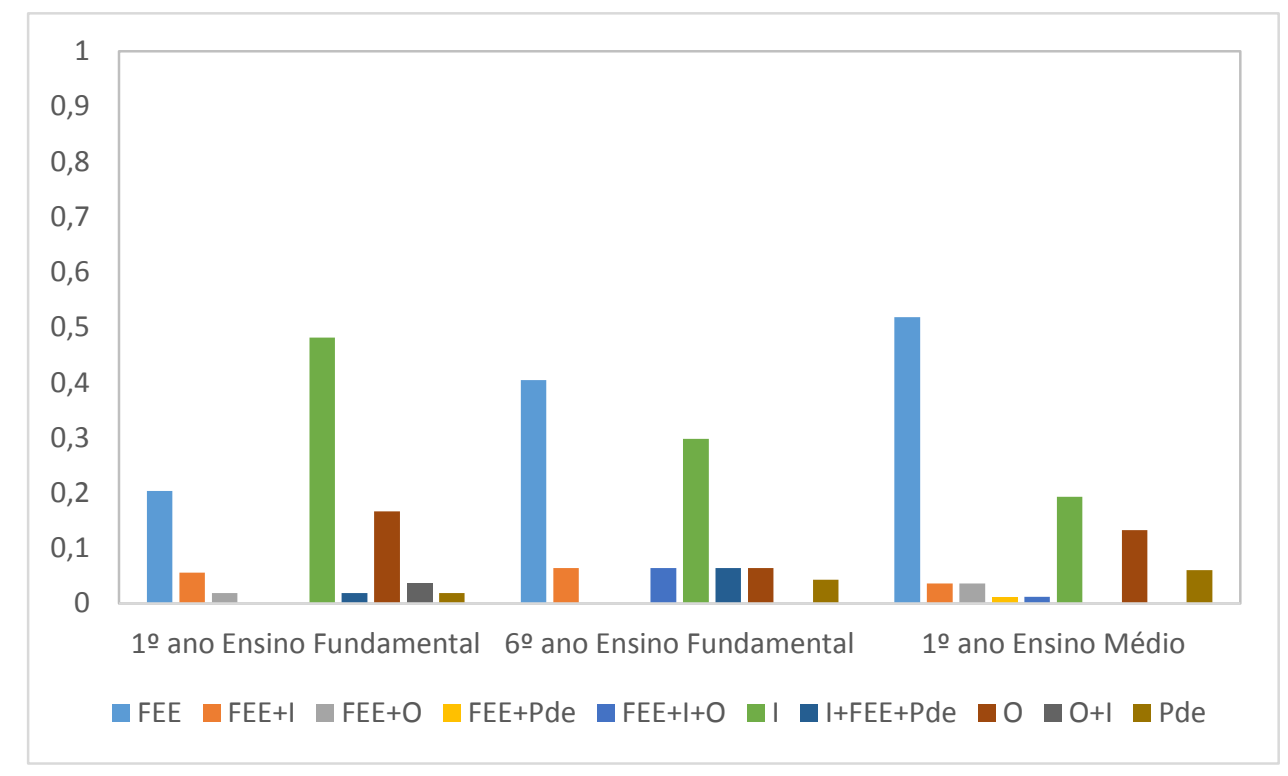

Figura 14. Proporções de citações das categorias de rejeição, citadas isoladamente ou em conjunto com outras, relativas ao total de citações das categorias em cada ano. FEE=Falta de Engajamento nos Estudos; I=Indisciplina; O=Outros; Pde=Presença de Déficits.

Conforme apresentado na Figura 14, dentre as categorias de rejeição, "Falta de Engajamento nos Estudos" e "Indisciplina" foram as mais mencionadas pelos professores dos três anos escolares. Destaca-se que a proporção de menções isoladas de "Falta de Engajamento nos Estudos" apresenta um aumento ao longo dos anos escolares avaliados, ao passo que a de "Indisciplina" apresenta uma redução. No 1을 ano do Ensino Fundamental, a categoria "Outros" foi a terceira mais mencionada sozinha, sendo sua proporção próxima à de "Falta de Engajamento nos Estudos". No 1o ano do Ensino Médio, "Outros" também foi a terceira categoria mais indicada, com uma proporção próxima à de "Indisciplina". No 60 ano do Ensino Fundamental, por sua vez, as proporções de citações das outras categorias foram expressivamente menores que as de "Falta de Engajamento nos Estudos" e 
"Indisciplina". Observa-se, ainda, que a frequência de citações de categorias em conjunto foi baixa em todos os anos, quando comparada à frequência de menções de categorias isoladas.

A análise inferencial indicou uma diferença estatisticamente significativa na distribuição do número de citações de cada categoria de rejeição entre os três anos escolares ( $p$-valor=0,000).

\section{Discussão}

A partir dos dados acima apontados nesta seção, nota-se que "Engajamento nos Estudos" e "Disciplina" foram as categorias mais citadas como razões para aceitação e que "Falta de Engajamento nos Estudos" e "Indisciplina" foram mais mencionadas como razões para rejeição, em todos os anos escolares avaliados no presente estudo.

As categorias referentes ao engajamento nos estudos, tanto as de aceitação quanto as de rejeição, estão fortemente relacionadas às habilidades acadêmicas e à motivação e iniciativa para realizar as atividades escolares, conforme pode ser observado a partir das respostas que as constituem. Desta forma, os resultados ratificam o que é apontado pela literatura acerca do fato de que as relações do professor com o aluno que chega à escola com habilidades acadêmicas mais desenvolvidas, que não possui uma história de fracasso escolar ou que é altamente motivado para realizar determinadas atividades ou para estudar (Jerome et al., 2008; Nurmi, 2012; Viecili \& Medeiros, 2002) são melhores que as relações com o aluno que possui dificuldades acadêmicas, um histórico com retenções ou que não possui iniciativa para fazer as atividades (Azevedo et al., 2012; Baker, 2006; Nurmi, 2012; Viecili \& Medeiros, 2002). Trata-se de um dado preocupante, visto que os alunos com problemas nas habilidades acadêmicas são alguns dos que mais precisam do apoio do professor (Osti \& Martinelli, 2014). No sistema público brasileiro de ensino, é comum que o professor de criança com tais déficits não estabeleça contingências favoráveis a sua aprendizagem, com alta probabilidade dessas dificuldades aumentarem e afetarem o repertório social da criança, ficando ela rotulada como problemática.

A categoria "Indisciplina", por seu turno, apresenta relação com problemas de comportamento, ao passo que "Disciplina" consiste no seu oposto, ou seja, representa alunos que, além de não possuírem problemas de comportamento, apresentam atitudes adequadas às demandas da escola. 
Conforme apontado na literatura, os alunos que possuem problemas de comportamento em sala de aula são mais propensos a se envolver em relações com o professor marcadas pelo conflito e com pouco apoio sócio emocional (Farmer et al., 2011; Picado \& de Rose, 2009). Portanto, os resultados relativos às categorias "Disciplina" e "Indisciplina" também ratificam os dados da literatura e são igualmente preocupantes, visto que os estudantes vistos pelos professores como sendo destrutivos recebem notas mais baixas (Dee, 2005).

Acerca da maior frequência de citações das categorias referentes ao engajamento nos estudos e à disciplina, levanta-se a hipótese de que se referem, respectivamente, a comportamentos que se relacionam diretamente ao objetivo explícito da escola de passar conhecimentos aos alunos e à possibilidade de manejo da sala de aula, a qual interfere na possibilidade do professor de lecionar. Sendo assim, trata-se de comportamentos que, ao chamarem mais a atenção do educador em seu dia a dia, positiva ou negativamente, são os que mais servem de base para a formação de seus julgamentos sobre os alunos.

Considerando as razões alegadas pelos professores para indicarem os alunos em cada uma das perguntas como sendo variáveis controladoras dos comportamentos dos docentes, pode-se levantar algumas hipóteses funcionais a respeito dos comportamentos dos estudantes relacionados às categorias mencionadas com maior frequência. Os comportamentos dos alunos categorizados como "Disciplina" e, especialmente, "Engajamento nos Estudos" podem se constituir como Estímulos Antecedentes que indicam ao professor que, caso ele invista na relação com os alunos que apresentam essas características, ele terá, com maior probabilidade, consequências reforçadoras (ou seja, são comportamentos que adquirem a função de Estímulo Discriminativo), pois seus alunos terão mais chances de obter sucesso e apresentar mais resultados frente ao trabalho do docente. Investindo mais na relação, os professores entram em contato com alunos mais disciplinados e engajados, consequência esta que reforça o comportamento de estabelecer uma relação de melhor qualidade com os estudantes. Indisciplina e Falta de Engajamento nos Estudos, por outro lado, se apresentam como Estímulos Antecedentes que indicam que o investimento na relação com esses alunos não produzirá 
consequências reforçadoras ao professor (portanto, são comportamentos que adquirem a função de Estímulo Delta). Não dando subsídios para os alunos melhorarem seus repertórios, os comportamentos dos alunos se mantêm os mesmos, permanecendo com a função de Estímulo Delta.

Comparando-se as categorias de aceitação mencionadas pelos professores ao longo dos anos, observou-se que "Engajamento nos Estudos" foi a resposta mais citada em todos os níveis. Os dados do Ensino Fundamental I são diferentes dos esperados pela hipótese levantada inicialmente na presente pesquisa no que se refere ao fato de que, nos primeiros anos, os aspectos comportamentais seriam mais importantes para o julgamento dos alunos. Por outro lado, coerentemente com a outra parte da hipótese, as citações de características correspondentes a aspectos acadêmicos se ampliaram significativamente nos dois anos seguintes, sugerindo que comportamentos relacionados a estes aspectos se tornam ainda mais relevantes para os professores julgarem seus alunos nos anos do Ensino Fundamental II e do Ensino Médio. Ademais, conforme esperado, comportamentos disciplinares foram menos citados no 6ㅇ ano e, principalmente, no Ensino Médio, quando comparado ao 10 ano do Ensino Fundamental.

Levanta-se a possibilidade de que comportamentos voltados aos estudos possuem uma importância similar aos comportamentos disciplinares, nos anos iniciais, para que os professores apresentem uma relação de boa qualidade com seus alunos. Porém, ao longo dos anos, os comportamentos voltados aos estudos se tornariam mais relevantes para aceitação pelo fato de, em anos escolares mais elevados, os professores serem mais avaliativos e mais focados no desempenho escolar dos estudantes.

Vale destacar, ainda, que uma possível razão para haver uma distribuição mais homogênea entre as razões relatadas pelos professores de 10 ano, quando comparada aos professores dos demais anos, é o fato dos docentes, por estarem em contato constante com seus alunos, terem a oportunidade de observar e avaliar comportamentos pertencentes a diferentes classes, não se limitando a apenas comportamentos acadêmicos ou disciplinares. 
Comparando-se as categorias de rejeição, observou-se que "Falta de Engajamento nos Estudos" foi citado com menor frequência do que "Indisciplina" no Ensino Fundamental I, enquanto, no Ensino Fundamental II e no Ensino Médio, essas frequências se inverteram, havendo, no último ano avaliado, uma acentuação da diferença entre as citações das duas categorias. Ainda que as diferenças entre o 1o e o 6 ano do Ensino Fundamental nas citações de "Indisciplina" e as diferenças entre o 60 ano e o Ensino Médio nas citações de "Falta de Engajamento nos Estudos" não tenham alcançado significância estatística, esse padrão encontrado ao longo dos três anos é coerente com a terceira hipótese levantada no presente trabalho acerca do fato de que, no 1 o ano do Ensino Fundamental, os aspectos comportamentais seriam mais relevantes para o julgamento realizado pelos professores e que, com o passar dos níveis, estes dariam lugar aos acadêmicos.

As variações encontradas entre os níveis escolares podem ser compreendidas pelo fato de, nos anos iniciais, quando comparados aos anos posteriores, os relacionamentos com os alunos serem menos voltados para os conteúdos cognitivos, especialmente nos três primeiros anos escolares que constituem o ciclo de alfabetização, e os professores apresentarem uma maior preocupação com os aspectos afetivos e de cuidado das interações (Harter, 1996; Lynch \& Cicchetti, 1997; Maia et al., 2009; Soares et al., 2009), aspectos estes que são dificultados quando o aluno apresenta comportamentos indisciplinares. Por outro lado, conforme Bierman (2011) defende, em anos escolares mais elevados, os professores lidam menos com os problemas de comportamento de seus alunos, estando mais focados em seu desempenho acadêmico. Assim, problemas no engajamento nos estudos se tornam mais relevantes do que problemas de indisciplina para os professores julgarem os comportamentos de seus estudantes. Esse aumento ocorre particularmente no Ensino Médio, dado que a exigência para os estudos se torna maior em uma fase na qual os vestibulares se aproximam, muitos alunos ingressam no mercado de trabalho - sendo a conclusão do Ensino Médio um pré-requisito para muitas vagas - e são aplicadas as provas que avaliam a qualidade de ensino da escola. Em termos funcionais, levanta-se a hipótese de que cada nível escolar exerce um controle diferencial como Estímulo Antecedente, seja 
devido ao currículo escolar diferenciado ou ao que é esperado dos alunos em função de suas idades, por exemplo.

Desta forma, as razões para aceitação e rejeição nos três níveis estudados sugerem que os comportamentos que atraem aprovações ou desaprovações do professor não são os mesmos nos diferentes níveis escolares. Trata-se, portanto, de um dado que parece diferir em parte dos apresentados pela revisão de Beaman e Wheldall (2000). Ainda que os resultados do presente estudo de fato sugiram que o comportamento acadêmico adequado é mais provável de atrair elogios e aprovações do professor do que o comportamento social adequado, não houve confirmação das conclusões dos autores de que o comportamento social inadequado chama mais a atenção do professor que $\mathrm{o}$ acadêmico inadequado.

Quanto às respostas relativas à presença de dificuldades, no caso da aceitação, é importante observar o número reduzido de professores que dão suporte a alunos que precisam de um apoio diferencial, o qual é necessário para que o estudante desenvolva repertórios mais favoráveis (Baker, 2006; Burchinal et al., 2002; Hamre \& Pianta, 2005; Meehan et al., 2003). No caso das respostas referentes à presença de déficits, para rejeição, sugere-se que se tratam de docentes que não apenas não fornecem essa atitude diferencial, como também delegam explicitamente a outros profissionais o papel do cuidado a esses alunos. A partir disso, questiona-se o quanto os docentes estão preparados para lidar com alunos com necessidades especiais, que vêm ocupando um espaço maior nas escolas públicas. Os dados referentes a essas duas categorias, podem tornar questionável a ideia de que os professores ajustam seu comportamento diante dos estudantes a depender de suas necessidades (Corno, 2008). Por outro lado, o elevado número de alunos aceitos por engajamento nos estudos e rejeitados por falta dele dão maior suporte para a teoria da profecia auto-realizadora (Rotter, 1967).

Em relação às categorias "Outros", tanto a de aceitação quanto a de rejeição, é importante salientar que foram mencionadas, em alguns casos, com frequência mais alta ou próxima que "Presença de Déficits" e "Presença de Dificuldades" e que apresentaram variações a depender dos fatores acima 
analisadas. No entanto, por se tratar de uma categoria demasiadamente heterogênea ${ }^{6}$, sem especificações acerca das respostas que as constituem, torna-se improdutivo levantar hipóteses acerca dos dados a ela relativos.

\section{Outros fatores}

É possível que outras variáveis contextuais também exerçam controle sobre as posturas dos professores, tais como seus salários, a carga horário de seu trabalho e a disciplina que leciona. Por exemplo, as diferentes áreas em que o professor leciona, por apresentarem diferentes objetivos curriculares, podem modificar o julgamento do professor referente a quais comportamentos os alunos devem apresentar. Deste modo, visando a investigar a possibilidade da área em que o professor leciona ter relação com os resultados acima apontados, analisaram-se as possíveis associações entre as áreas e as categorias mencionadas pelos docentes. A Tabela 3 apresenta os números absolutos e as proporções, em relação ao total de professores de cada ano, de docentes que lecionam em cada área nos três anos estudados.

Tabela 3:

Números e porcentagens de docentes que lecionam em cada área nos três anos escolares

\begin{tabular}{lcccccc} 
& \multicolumn{2}{c}{ 10 Ensino Fundamental } & \multicolumn{2}{c}{ 60 Ensino Fundamental } & \multicolumn{2}{c}{ 10 Ensino Médio } \\
\cline { 2 - 8 } & $\begin{array}{l}\text { Número } \\
\text { absoluto }\end{array}$ & Porcentagem & $\begin{array}{c}\text { Número } \\
\text { absoluto }\end{array}$ & Porcentagem & $\begin{array}{c}\text { Número } \\
\text { absoluto }\end{array}$ & Porcentagem \\
\hline Grupo A & 2 & $9,50 \%$ & 9 & $56 \%$ & 24 & $85,70 \%$ \\
\hline Grupo B & 6 & $28,50 \%$ & 6 & $37,50 \%$ & 4 & $14,30 \%$ \\
\hline Outros & 3 & $14,30 \%$ & 1 & $6,20 \%$ & 0 & $0 \%$ \\
\hline Polivalente & 10 & $47,60 \%$ & 0 & $0 \%$ & 0 & $0 \%$ \\
\hline
\end{tabular}

A Figura 15 se refere às diferenças nas proporções de citações das categorias de aceitação pelos professores, em relação ao total de citações realizadas pelos docentes de cada área. Neste cálculo,

\footnotetext{
${ }^{6}$ Encontram-se no APÊNDICE G as respostas de aceitação e de rejeição classificadas em "Outros" e o número de vezes em que elas foram mencionadas a depender do ano escolar, do sexo do aluno, do sexo do professor e da área na qual ele leciona.
} 
contabilizou-se o número total de citações das categorias, independentemente de terem sido mencionadas isoladamente ou em conjunto com outras categorias.

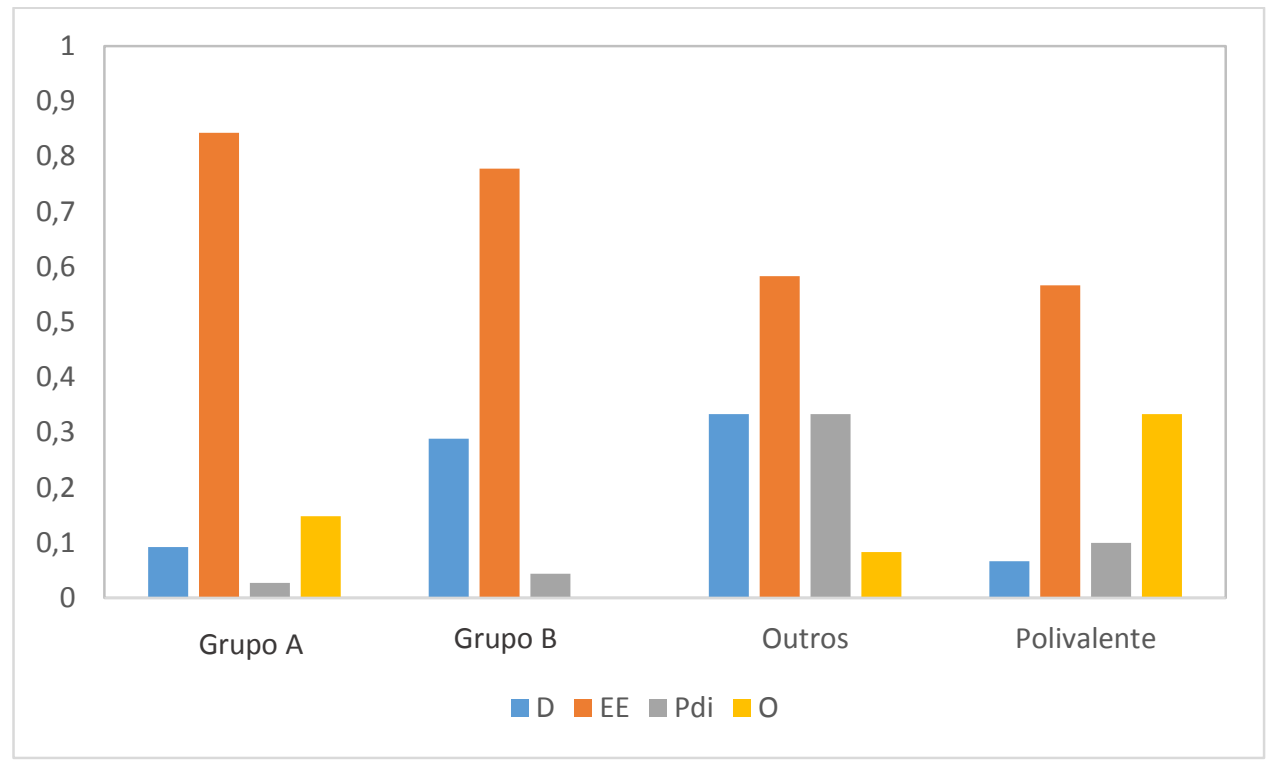

Figura 15. Proporções de citações das categorias de aceitação realizadas pelos professores de cada área, contabilizando-se o total de menções, independentemente de terem sido realizadas isoladamente ou

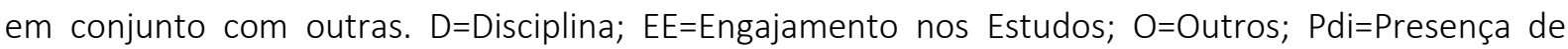
Dificuldades.

A partir da Figura 15, é possível observar que houve uma maior proporção de citações da categoria "Disciplina" por professores da área "Outros", seguido do Grupo A, do Grupo B e "Polivalente". As maiores diferenças observadas foram entre professores do Grupo A e de "Outros" e, também, entre professores do Grupo B e de "Polivalente". A análise inferencial indicou que houve diferença estatisticamente significativa apenas entre a proporção de professores do Grupo A e do Grupo B que citaram a categoria "Disciplina" ( $p$-valor<0,008). É possível que este dado seja decorrente do fato de que os objetivos curriculares de matérias do Grupo B, tal como educação física, tornem os professores mais propensos a exigir de seus alunos comportamentos disciplinares, quando comparados a docentes de matérias acadêmicas. Portanto, a área em que o professor leciona pode exercer a função de Estímulo Antecedente para o comportamento do professor de reforçar atitudes dos alunos que se insiram na categoria "Disciplina" (Kubo \& Bomoté, 2001). 
Observa-se que os resultados relativos às citações de "Disciplina" podem ter relação com a diferença acima relatada. No 1o ano do Ensino Fundamental, há uma proporção maior de professores do Grupo B, quando comparada à do Grupo $A$, sendo que, neste ano escolar, a proporção de citações de "Disciplina" é a maior dentre os níveis. Já no 6o ano, as proporções de professores dessas duas áreas se invertem, juntamente com uma queda na proporção de menções a "Disciplina". No 1o ano do Ensino Médio, por sua vez, esta diferença entre os professores das duas áreas, observada no 60 ano, se acentua, sendo que há uma redução considerável de citações de "Disciplina".

Quanto à categoria "Engajamento nos Estudos", nota-se que ela é citada por uma maior proporção de professores do Grupo A, seguidos de professores do Grupo B. Em terceiro e quarto lugar estão, respectivamente, "Outros" e "Polivalente". Dentre as diferenças observadas pelo gráfico, apenas a apresentada entre professores do Grupo A e "Polivalente" foi estatisticamente significativa ( $p$ valor<0,008). Levanta-se a hipótese de que isso se deva ao fato de que os professores polivalentes, por terem um contato mais constante com seus alunos, possuem maior acesso e avaliam mais comportamentos, além dos relativos aos estudos. Desta forma, ainda que estes comportamentos sejam possivelmente os mais relevantes para os professores polivalentes, outros comportamentos também se mostram importantes no momento em que o docente realiza seus julgamentos.

Vale destacar que menos professores de 1ㅇano do Ensino Fundamental eram do Grupo a e mais eram da área "Polivalente", sendo que este número se inverte nos anos seguintes, nos quais não há docentes polivalentes e cujo número de educadores do Grupo A aumentou, tornando-se expressivamente maior no Ensino Médio (Tabela 3). Desta forma, embora "Engajamento nos Estudos" tenha sido o mais citado entre os três anos, o fato de suas menções ter se ampliado do 1 o ano do Ensino Fundamental para os demais pode ter relação com as áreas nas quais os professores participantes lecionam.

No que se refere à categoria de aceitação "Presença de dificuldades", houve uma maior proporção de citações por parte de professores da área "Outros", a qual se diferenciou expressivamente 
dos professores das demais áreas. No entanto, apenas a diferença entre a proporção de professores de "Outros" e do Grupo A foi estatisticamente significativa ( $p$-valor $<0,008)$.

Por fim, em relação à categoria de aceitação "Outros", professores da área "Polivalente" foram os que mais mencionaram esta resposta, seguidos de professores do Grupo A e da área "Outros". Nenhum professor do Grupo B citou esta categoria. A análise inferencial indicou que a diferença entre professores do Grupo A e do Grupo B foi marginalmente significativa ( $p$-valor=0,008) e entre "Outros" e o Grupo B foi estatisticamente significativa ( $p$-valor $<0,008$ ). A diferença entre as demais áreas não apresentou significância estatística.

A Figura 16 indica as diferenças nas proporções de citações das categorias de rejeição pelos professores, em relação ao total de citações realizadas pelos docentes de cada área. Neste cálculo, contabilizou-se o número total de citações das categorias, independentemente de terem sido mencionadas isoladamente ou em conjunto com outras categorias.

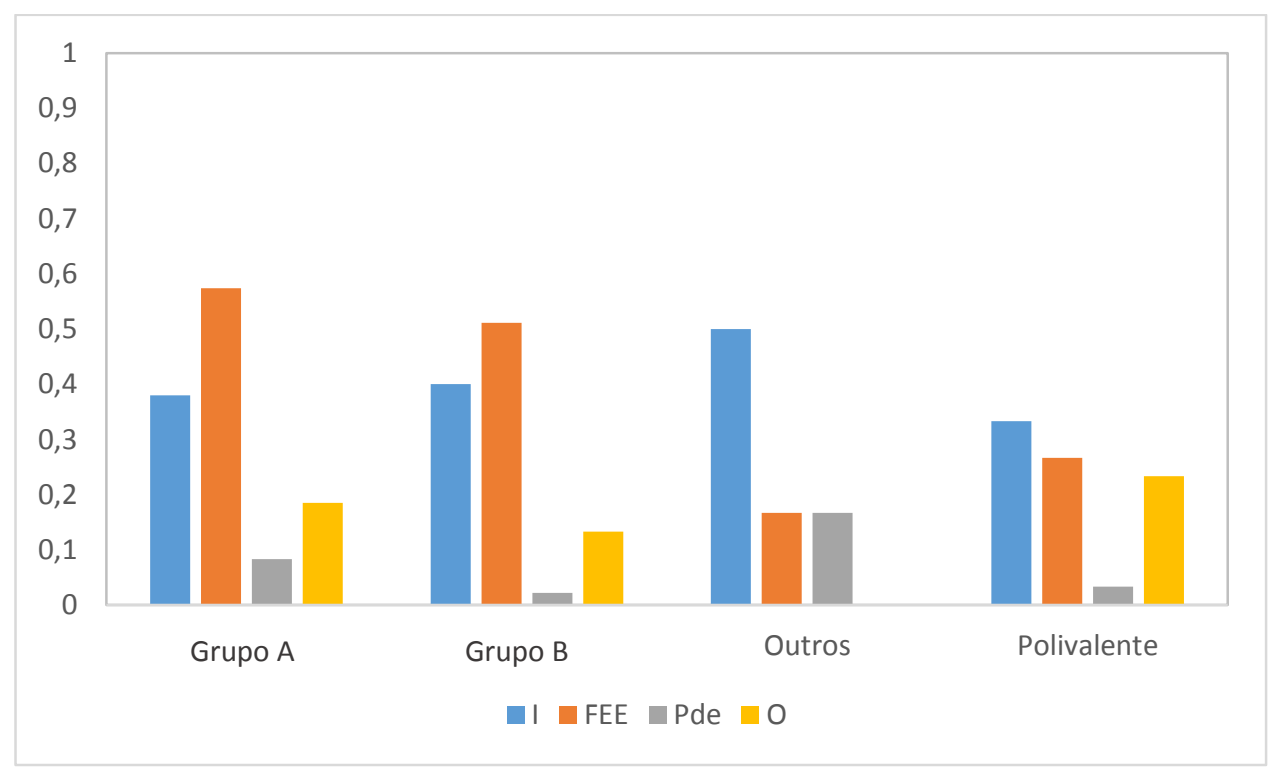

Figura 16. Proporções de citações das categorias de rejeição realizadas pelos professores de cada área, contabilizando-se o total de menções, independentemente de terem sido realizadas isoladamente ou em conjunto com outras. FEE=Falta de Engajamento nos Estudos; I=Indisciplina; O=Outros; Pde=Presença de Déficits. 
Nota-se, a partir da Figura 16, uma distribuição homogênea nas proporções de citações da categoria "Indisciplina" entre os professores das diferentes áreas. Ainda que haja uma maior diferença entre os professores de "Outros" e os professores de "Polivalente", nenhuma diferença atingiu significância estatística. Portanto, sugere-se que as diferenças observadas entre os anos escolares não tenham relação com a área em que o professor leciona.

Quanto à "Falta de Engajamento nos Estudos", professores do Grupo A e do Grupo B apresentam uma maior proporção de citações do que os professores das duas outras áreas. No entanto, apenas a diferença entre o Grupo A e "Polivalente" se mostrou estatisticamente significativa ( $p$ valor $<0,008)$. Analogamente ao que foi dito acima quanto à possível relação entre a área em que o professor leciona e as diferenças observadas na categoria "Engajamento nos Estudos" ao longo dos anos escolares, os diferentes números de citações de "Falta de Engajamento nos Estudos" entre os anos pode ter relação com a área de ensino dos docentes.

Em relação às categorias de rejeição "Presença de Déficits" e "Outros", ainda que se observem diferenças entre as proporções de citações por parte dos professores das diferentes áreas, nenhuma delas atingiu significância estatística.

\subsubsection{Razões para as indicações versus sexo do aluno}

\section{Resultados}

Quanto às relações entre as categorias mencionadas pelos professores e o sexo dos alunos, a Figura 17 apresenta uma comparação, entre alunos e alunas, das proporções de menções das categorias de aceitação em relação aos totais de citações destas categorias. Neste cálculo, contabilizou-se o número total de citações das categorias, independentemente de terem sido mencionadas isoladamente ou em conjunto com outras categorias. 


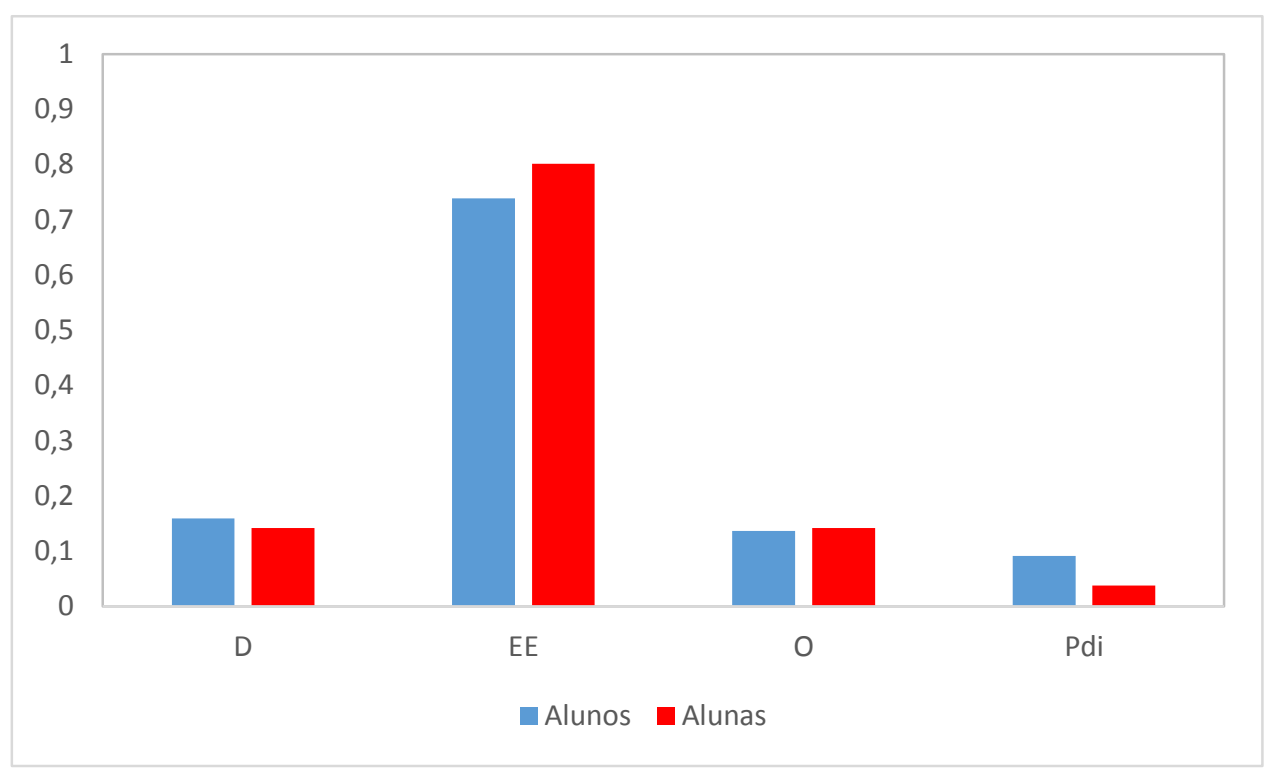

Figura 17. Proporções de meninas e meninos aceitos por cada razão, contabilizando-se juntamente as categorias mencionadas isoladamente e as citadas em conjunto com outras. D=Disciplina; $\mathrm{EE}=$ Engajamento nos Estudos; O=Outros; Pdi=Presença de Dificuldades.

A partir da Figura 17, observam-se pequenas diferenças entre a proporção de citações de meninos e de meninas em cada categoria, mas a análise inferencial indicou que estas diferenças não foram estatisticamente significativas (respectivamente, $p$-valor=0,857; $p$-valor=0,319; $p$-valor=1,000; $p$ valor $=0,158)$.

Na Figura 18, são consideradas separadamente as categorias mencionadas sozinhas e as citadas juntamente com outras, comparando-se, entre os sexos dos alunos, as proporções de citações das categorias de aceitação relativas aos totais de citações realizadas em cada sexo. 


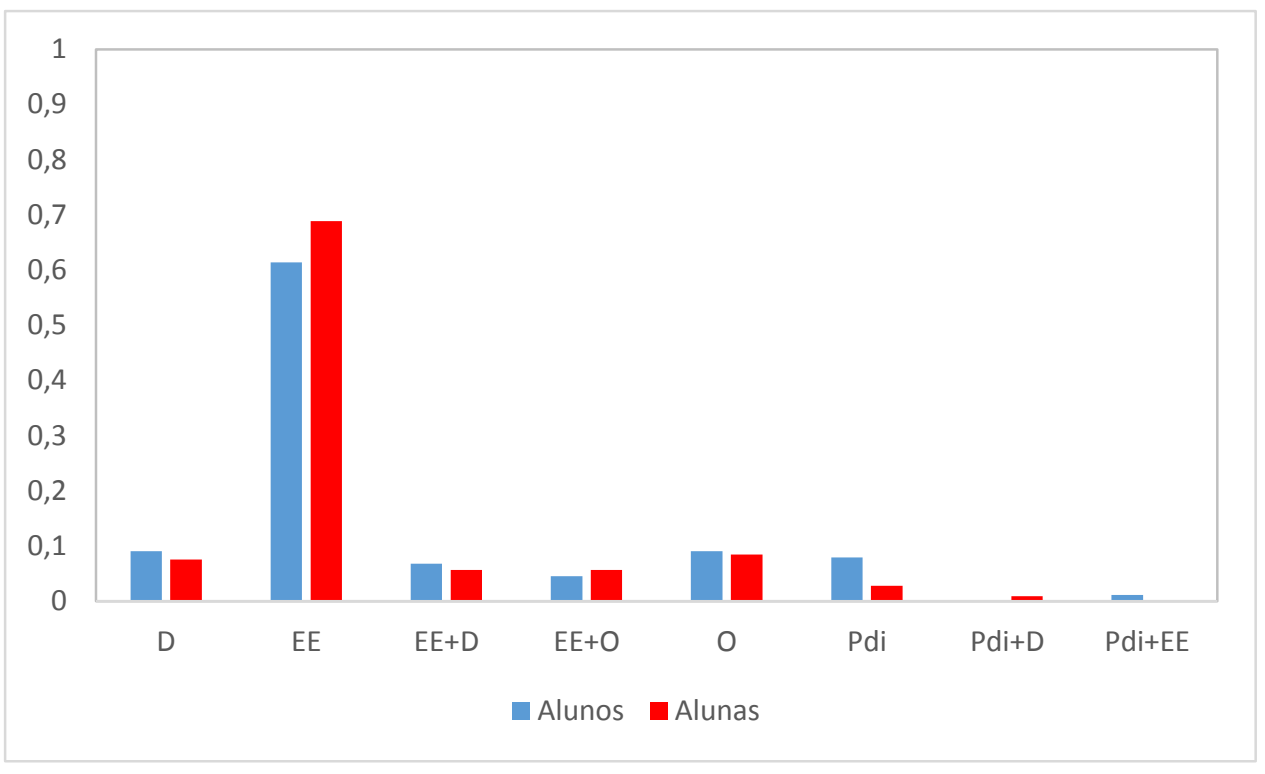

Figura 18. Proporções de meninas e meninos aceitos por cada razão, considerando-se separadamente as categorias mencionadas isoladamente e as citadas juntamente com outras. D=Disciplina; $\mathrm{EE}=$ Engajamento nos Estudos; $\mathrm{O}=$ Outros; Pdi=Presença de Dificuldades.

A Figura 18 indica algumas diferenças entre meninas e meninos, havendo, por exemplo, uma proporção maior de alunos indicados, juntamente, por "Engajamento nos Estudos" e "Disciplina" do que a proporção de alunas, e, por outro lado, uma maior proporção de meninas citadas por "Engajamento nos Estudos" e "Outros". No entanto, as diferenças nas distribuições das razões para aceitação entre os alunos de cada sexo não foram estatisticamente significativas ( $p$-valor=0,678).

No que se refere às categorias de rejeição, a Figura 19 apresenta uma comparação, entre alunos e alunas, das proporções de menções dessas categorias em relação aos totais de suas citações em cada sexo, tendo sido contabilizado o número total de citações das categorias, independentemente de terem sido mencionadas isoladamente ou em conjunto com outras. 


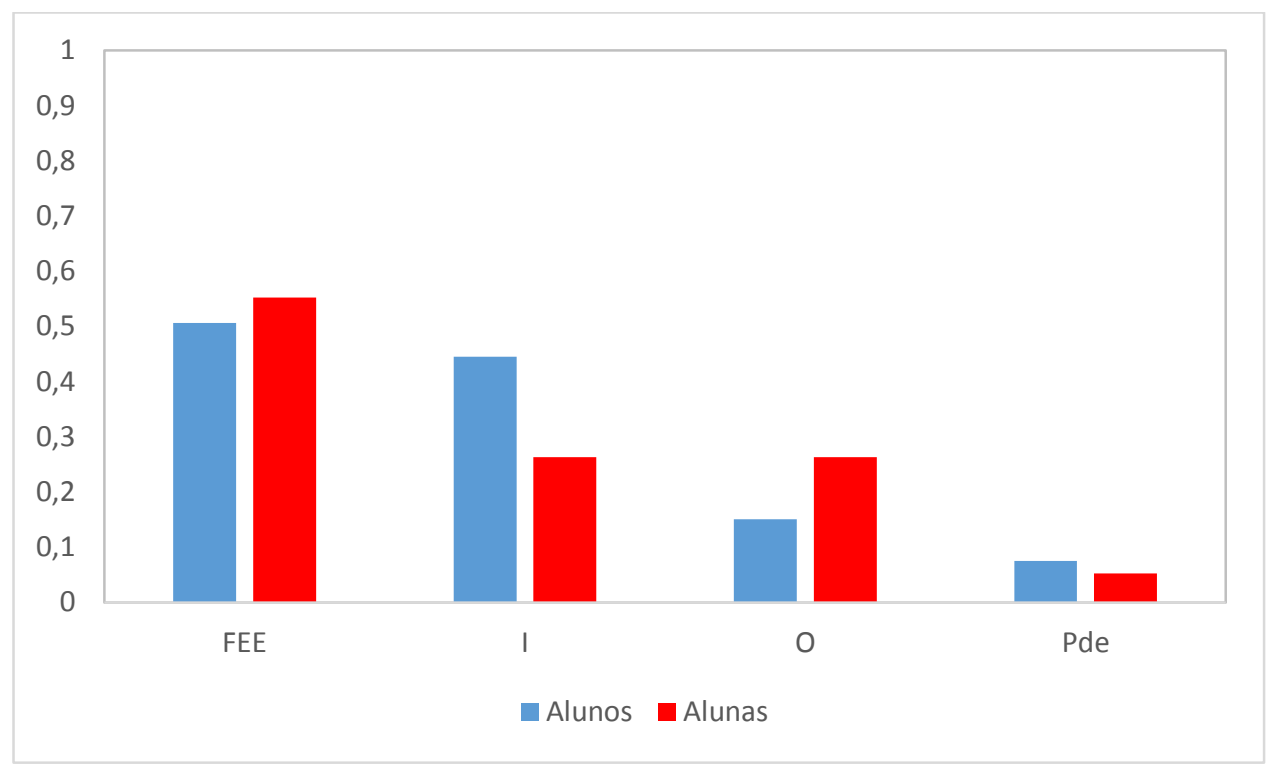

Figura 19. Proporções de meninas e meninos rejeitados por cada razão, contabilizando-se juntamente as categorias mencionadas isoladamente e as citadas em conjunto com outras. FEE=Falta de Engajamento nos Estudos; I=Indisciplina; O=Outros; Pde=Presença de Déficits.

A Figuras 19 indica que houve uma maior proporção de meninas citadas na pergunta relativa à rejeição por "Falta de Engajamento nos Estudos" e por "Outros", quando comparada à proporção de meninos. Nas demais categorias, houve uma proporção maior de indicações de meninos. No entanto, a análise inferencial indicou que apenas a diferença obtida na categoria "Indisciplina" foi marginalmente significativa ( $p$-valor=0,059), sendo que as demais diferenças não foram estatisticamente significativas.

Na Figura 20, são consideradas separadamente as categorias mencionadas sozinhas e as citadas juntamente com outras, comparando-se, entre os sexos dos alunos, as proporções de citações das categorias de rejeição relativas aos totais de citações realizadas em cada sexo. 


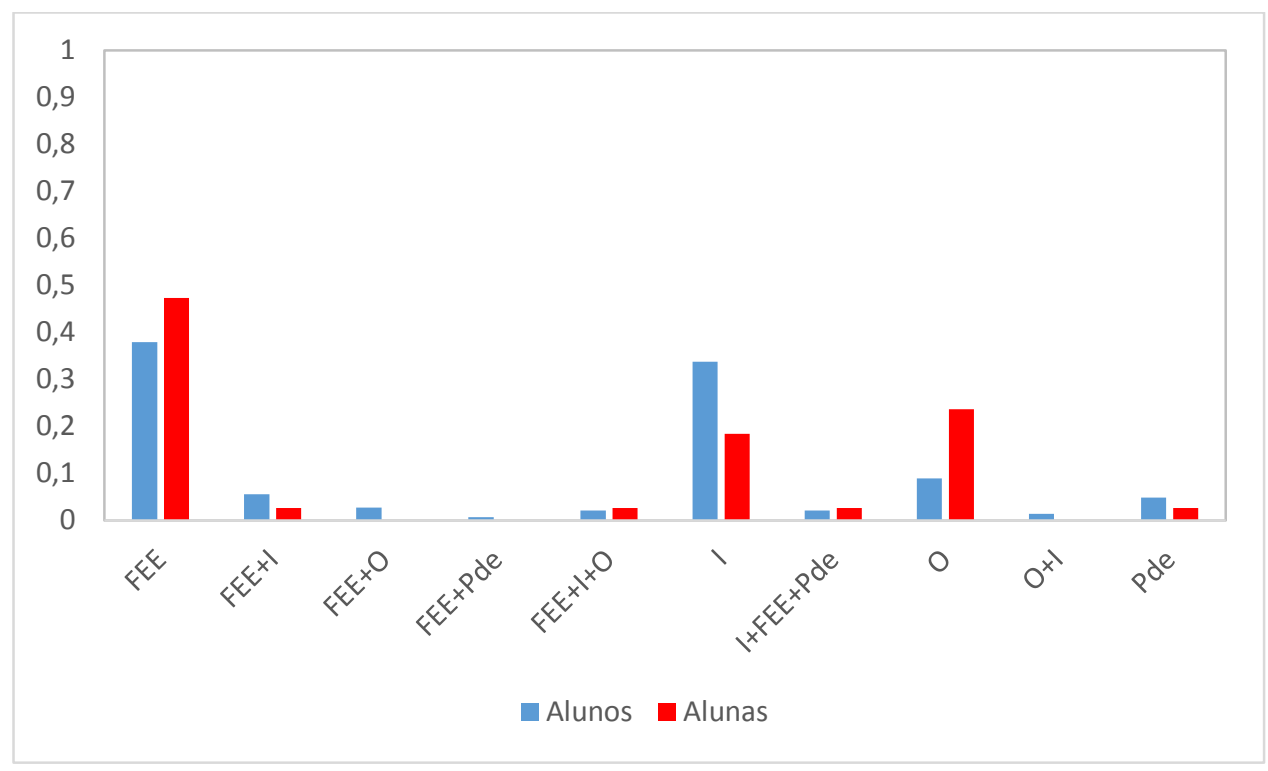

Figura 20. Proporções de meninas e meninos rejeitados por cada razão, considerando-se separadamente as categorias mencionadas isoladamente e as citadas juntamente com outras. FEE=Falta de Engajamento nos Estudos; I=Indisciplina; O=Outros; Pde=Presença de Déficits.

A partir da Figura 20, observa-se que houve uma maior proporção de meninas citadas por "Falta de Engajamento nos Estudos" e "Outros" isoladamente e uma maior proporção de meninos citados por "Indisciplina" e por "Presença de Déficits", ainda que estas diferenças tenham sido baixas. No que se refere às categorias mencionadas em conjunto, notam-se diferenças entre os sexos, mas elas são ainda menores que as diferenças encontradas nas categorias citadas isoladamente. A análise inferencial indicou que as diferenças nas distribuições das razões para rejeição entre os alunos de cada sexo não foram estatisticamente significativas ( $p$-valor $=0,258$ ).

\section{Discussão}

Em termos gerais, os resultados apontam não haver diferenças entre meninas e meninos quanto às razões que os levam a ser indicados na pergunta relativa à aceitação. Ao se analisar esses dados encontrados, é possível levantar a hipótese de que são função de semelhanças nos comportamentos apresentados pelos meninos e pelas meninas e/ou à mesma importância que o docente atribui aos comportamentos dos alunos dos dois sexos para indicá-los. 
Dentre as razões para rejeição, a maior diferença observada entre meninas e meninos foram relativas a "Indisciplina", a qual foi marginalmente significativa. Analogamente à análise feita em relação às razões para aceitação, pode-se levantar a hipótese de que esse dado reflita diferenças nos comportamentos inadequados apresentados pelos meninos e pelas meninas, sendo os meninos mais indisciplinados do que as meninas. Isto é, em parte, coerente com dados apontados pela literatura nacional, segundo os quais os meninos são vistos como mais agressivos e agitados e menos obedientes (Da Silva et al., 1999; Gardinal \& Marturano, 2007; Maia, Navarro, \& Maia, 2011). Por outro lado, essa mesma literatura também indica que alunos do sexo masculino são vistos como mais dispersos e menos atentos e estudiosos, características essas mais associadas à categoria "Falta de Engajamento nos Estudos" e cuja proporção de meninos e meninas foi similar.

É importante destacar que as diferenças entre comportamentos externalizantes e internalizantes, as quais se esperava encontrar nas comparações feitas para atingir ao terceiro objetivo do estudo, não foram identificadas e avaliadas. Isso foi decorrente do fato de que as categorias desenvolvidas com base nas respostas fornecidas pelos participantes não puderam englobar uma separação entre problemas de comportamento do tipo internalizante e do tipo externalizante, pois esta distinção não se apresentou claramente entre as respostas fornecidas. Ainda que a categoria "Indisciplina" apresente respostas relacionados a comportamentos externalizantes (tais como "violento", "agressivo", "arruma muita confusão"), muitas das respostas desta categoria não estão necessariamente associadas a tais tipos de problema (por exemplo, "apresenta certa indisposição com todos os alunos" e "arrogância").

\section{Outros fatores}

Com o objetivo de investigar se as associações observadas entre o sexo dos alunos indicados e as categorias mencionadas apresentam relação com o sexo do professor, analisaram-se as relações entre os sexos dos docentes e as razões por eles alegadas para nomear os estudantes. A Figura 21 indica 
as diferenças nas proporções de citações das categorias de aceitação pelos professores, em relação ao total de citações realizadas pelos docentes de cada sexo. Neste cálculo, contabilizou-se o número total de citações das categorias, independentemente de terem sido mencionadas isoladamente ou em conjunto com outras categorias.

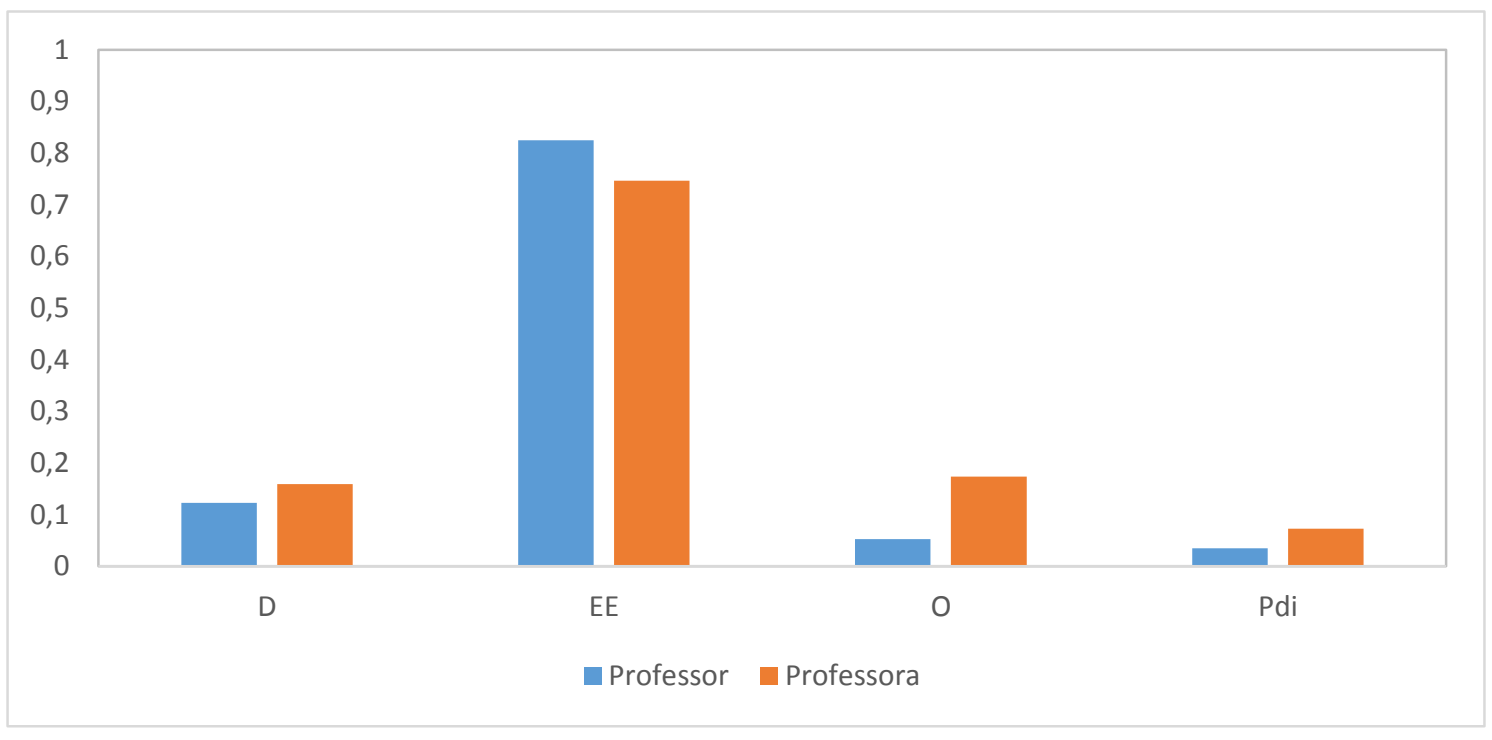

Figura 21. Proporções de citações das categorias de aceitação realizadas pelos professores de cada sexo, contabilizando-se o total de menções, independentemente de terem sido realizadas isoladamente ou em conjunto com outras. D=Disciplina; EE=Engajamento nos Estudos; $\mathrm{O}=$ Outros; Pdi=Presença de Dificuldades.

Conforme apresentado na Figura 21, uma maior proporção de professores do sexo masculino, quando comparada a de professores do sexo feminino, mencionou "Engajamento nos Estudos". As demais categorias foram mencionadas por uma maior proporção de professoras, quando comparada à de professores, sendo esta diferença mais acentuada no caso de "Outros" e a única, dentre todas as indicadas na Figura 21, estatisticamente significativa ( $p$-valor=0,033).

A Figura 22 indica as diferenças nas proporções de citações das categorias de rejeição pelos professores, em relação ao total de citações realizadas pelos docentes de cada sexo. Neste cálculo, contabilizou-se o número total de citações das categorias, independentemente de terem sido mencionadas isoladamente ou em conjunto com outras categorias. 


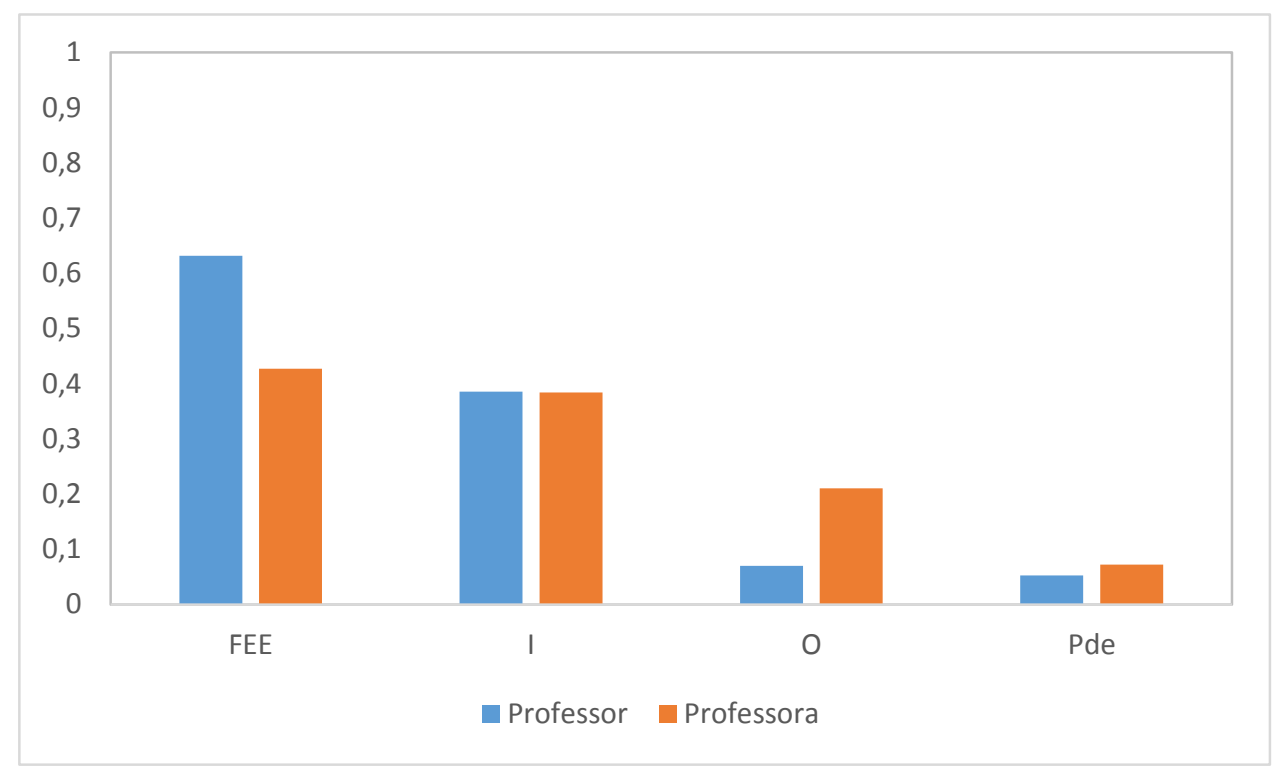

Figura 22. Proporções de citações das categorias de rejeição realizadas pelos professores de cada sexo, contabilizando-se o total de menções, independentemente de terem sido realizadas isoladamente ou em conjunto com outras. FEE=Falta de Engajamento nos Estudos; I=Indisciplina; O=Outros; Pde=Presença de Déficits.

Observa-se, por meio da Figura 22, que uma maior proporção de professores do que de professoras citaram "Falta de Engajamento nos Estudos" como razão para rejeição, ao passo que uma maior proporção de professoras citou "Outros", sendo estas diferenças estatisticamente significativas (respectivamente, $\mathrm{p}$-valor=0,008; $p$-valor=0,024). A proporção de citações de "Presença de Déficits" foi próxima para professores e para professoras e a mesma para "Indiferença", sendo que as diferenças nestes dois últimos não foram estatisticamente significativas.

Nota-se que apenas as diferenças na categoria "Outros", para aceitação e rejeição, e na "Falta de Engajamento nos Estudos", para rejeição, foram estatisticamente significativas, havendo uma maior proporção de professoras citando aquela e uma maior proporção de professores citando esta. Apesar da existência destas diferenças, elas não justificam os padrões encontrados nas relações, acima apresentadas, entre os sexos dos alunos e as categorias mencionadas, dado que foi encontrada diferença apenas na proporção de alunas e alunos indicados por "Indisciplina". 
Capítulo 6

Limitações, dificuldades e direcionamentos futuros 
Ao se considerar os resultados apresentados no presente estudo, deve-se ter em vista algumas de suas limitações. Destaca-se que não foram realizadas observações dos comportamentos das crianças indicadas, o que impossibilita identificar se as diferenças encontradas são decorrentes de características distintas presentes entre os alunos dos dois sexos e/ou dos três anos estudados, se são fruto de percepções diferenciadas dos professores ou se ambos influenciaram o fenômeno em questão. Deste modo, sugere-se que estudos futuros incluam, em seus métodos, observações em sala de aula ou outros procedimentos que possibilitem investigar os comportamentos que de fato são apresentados pelos estudantes.

Ademais, o delineamento do presente estudo, por não realizar um acompanhamento dos participantes durante um período de tempo e não manipular as variáveis avaliadas (Breakwell, Hammond, Fife-Schaw, \& Smith, 2010), não possibilita inferir relações de causalidade entre as variáveis estudadas. Ainda que se entenda que os fatores estudados apresentem alguma associação com a qualidade da interação professor-aluno, não se pode concluir se eles antecedem a interação estabelecida, se são consequentes a ela ou se tanto os fatores quanto a interação são consequentes de variáveis não incorporadas no estudo - não havendo, neste último, relação direta de causa e efeito entre as variáveis pesquisadas. Sugerem-se, deste modo, pesquisas com delineamentos diferenciados que propiciem um conhecimento mais pormenorizado dessas relações.

Outra limitação que deve ser salientada diz respeito às características do professor que não puderam ser acessadas e que possivelmente interferiram nas percepções a respeito de seus alunos (Bergin \& Bergin, 2009; Buyse et al., 2008; Soares et al., 2010; Tacca \& Branco, 2008), tais como suas crenças e atribuições, história familiar, experiência com cada tipo de aluno, habilidades sociais e saúde mental. Similarmente, características da sala (tal como a frequência de alunos com os comportamentos indicados pelo professor) e da escola (por exemplo, suas normas e valores) não foram avaliadas. Portanto, compreende-se a importância de pesquisas que abarquem estes aspectos em seus procedimentos. 
Vale destacar, ainda, que as análises estatísticas que envolveram as variáveis do professor (sexo e área em que leciona) possuem como limitação o fato da amostra não ter sido obtida considerando-se tais fatores, dado que tais análises não constituíram o objetivo principal da pesquisa. Desta forma, houve um número reduzido de professores do sexo masculino, bem como de docentes de cada área, o que pode ter levado às poucas relações encontradas entre os fatores analisados. Neste sentido, sugerese que os estudos futuros que se voltarem ao tema controlem as variáveis associadas ao educador, possibilitando obter dados suficientes para se depreender análises mais consistentes.

É importante considerar que, pelo fato do questionário ser constituído de questões abertas, criou-se a possibilidade dos professores fornecerem respostas muito amplas que dificultaram a elaboração de categorias com conteúdos mais específicos, tais como a presença de comportamentos externalizantes. Não apenas isto, mas essa característica das respostas fornecidas tornou necessária a criação da categoria "Outros", a qual foi mencionada um número considerável de vezes, ainda que a análise de seu conteúdo não seja possível.

No entanto, entende-se que fornecer aos participantes opções de possíveis razões para os professores assinalarem, além de limitar as possibilidades de respostas, aumentaria as chances deles indicarem razões pouco relevantes para a aceitação ou rejeição do aluno, por causa da facilidade em assinalar as alternativas. A realização de entrevistas, por seu turno, apesar de permitir solicitar maiores esclarecimentos das razões alegadas, pedir aos professores que indiquem, diante da pesquisadora, alunos aceitos e rejeitados e falem as razões para essas indicações pode fazer com que sejam dadas apenas respostas socialmente desejadas, incluindo a não indicação de crianças rejeitadas.

Relacionado à questão do que é socialmente desejado, questiona-se se este foi o motivo pelo qual alguns dos professores não responderam às perguntas relativas à rejeição ou se de fato os professores aceitam mais alunos do que rejeitam. Considerando-se que os professores costumam se atentar mais aos comportamentos inadequados do que aos adequados (Ulrich \& Kubo, 2004), seriam esperadas mais indicações de crianças rejeitadas. Similarmente, é possível que a preocupação dos participantes em fornecer respostas socialmente aceitas tenha sido a razão pela qual respostas 
relacionadas à etnia, ao nível socioeconômico e à aparência física não tenham sido mencionados em nenhum dos questionários. Procedimentos que evitem tais censuras devem ser elaborados para que as pesquisas possam investigar o que de fato interfere no julgamento que o professor faz de seus alunos.

Somando-se a essas limitações, algumas dificuldades presenciadas durante a execução do estudo devem ser explicitadas e analisadas. As dificuldades descritas no capítulo sobre o Estudo Piloto, as quais tornaram necessárias as mudanças realizadas nos procedimentos e no instrumento utilizado na coleta definitiva, abrem margem para reflexões a respeito dos professores de instituições públicas de ensino dos níveis escolares aqui estudados, no que se refere a suas qualificações, seus interesses e sua disponibilidade para participação em pesquisas.

Primeiramente, chamou a atenção a presença de professores que se mostraram interessados e disponíveis para preencher o questionário, mas que apresentavam dificuldades em responder até mesmo as questões de fácil compreensão (por exemplo, a dificuldade em conceber uma situação hipotética em que continuaria dando aulas para os mesmos alunos no ano seguinte, mesmo que eles passassem de ano). Em relação especificamente às implicações disto à presente pesquisa, indaga-se o quanto as respostas fornecidas pelos demais professores foram de fato provenientes de reflexões possibilitadas por uma compreensão adequada do instrumento. Em termos mais amplos, questiona-se a qualificação dos docentes para assumirem o papel de profissionais responsáveis pela transmissão de conhecimentos a crianças e adolescentes, entendendo-se a importância de um plano de ação para alterar este cenário.

Os professores que mostraram não querer participar da pesquisa (não devolvendo o questionário preenchido ou afirmando explicitamente não terem interesse), por seu turno, trazem o questionamento do quanto falta a compreensão por parte deles a respeito da importância da execução destes estudos. Ainda que façam críticas às suas condições de trabalho e, mais especificamente, às dificuldades no relacionamento com os alunos, não visualizam as vantagens da participação em investigações que se voltem ao entendimento de tais problemas. 
Possivelmente, isso se deve ao fato dessas vantagens estarem disponíveis somente em longo prazo, ou até mesmo não estejam disponíveis em nenhum momento. Alternativamente, ou somado a isso, o tempo de dedicação ao trabalho exigido pela sua profissão pode ser um empecilho a atividades que não se relacionem diretamente a ela, mesmo que elas demandem pouco tempo, tal como no caso do instrumento utilizado no presente estudo. Tendo isso em vista, uma possível solução seria informar esses profissionais a respeito da importância da participação em pesquisas, do quanto seus resultados podem se reverter em benefícios a eles próprios e de como isso será feito. Outro encaminhamento possível é a imersão da universidade na escola para que, dessa imersão, possam surgir as questões de pesquisa que sejam de interesse da própria instituição. Ademais, questiona-se o papel das universidades responsáveis pelas pesquisas no que se refere à origem e à manutenção da resistência dos professores em participar dos estudos. Particularmente, deve-se levar em consideração o fato das universidades fornecerem às escolas pouco ou nenhum retorno dos resultados obtidos nas pesquisas, deixando de convertê-las em benefícios aos próprios participantes.

É importante ressaltar que as dificuldades foram encontradas não somente diante dos professores, mas também antes mesmo da possibilidade de haver contato com eles. Muitas das escolas não autorizaram a realização da pesquisa em suas dependências, algumas delas alegando limitações burocráticas (por exemplo, necessidade de autorização da Diretoria de Ensino) e outras não chegando a permitir a exposição de informações acerca dos objetivos e procedimentos da pesquisa. É possível que de fato existam as limitações burocráticas referidas pelas escolas, mas pode-se questionar se esse foi o único motivo para a impossibilidade de acesso às escolas ou se ela foi decorrente, por exemplo, da falta de conhecimento sobre a importância das pesquisas acadêmicas, do excesso de tarefas as quais coordenadores e diretores são obrigados a cumprir, da falta de interesse, decorrente de seus baixos salários, em se engajar em atividades diferentes das quais são destinados a realizar ou, ainda, da falta de retorno, acima mencionada, das universidades responsáveis pelos estudos. Questiona-se se variáveis controladoras da própria postura de rejeição diante daqueles alunos que necessitariam de uma atenção 
diferenciada, tais como falta de tempo e baixos salários, também controlam a falta de adesão à pesquisa.

Não se pode deixar de mencionar a possibilidade do tema abordado nos questionários gerar a recusa das escolas e dos professores em participar do estudo, visto que os docentes devem explicitamente mostrar não apenas suas preferências por determinados alunos, como também pensamentos negativos que possuem acerca de outros. Caso o assunto estudado gerasse menos reprimenda social, é possível que a taxa de adesão fosse maior. 
Capítulo 7

Considerações finais 
O presente estudo teve por objetivo explicitar as variáveis controladoras da rejeição e da aceitação de alunos, relatadas por seus professores, avaliando-se as possíveis diferenças presentes entre o 1ㅇa ano do Ensino Fundamental I, o 6ㅇa ano do Ensino Fundamental II e o 1으 ano do Ensino Médio. Tendo atingido o objetivo proposto, a pesquisa, a despeito das limitações e dificuldades citadas no capítulo anterior, trouxe importantes contribuições, especialmente no que se refere à literatura nacional acerca do tema da relação professor-aluno e à abordagem analítico-comportamental aplicada a esse assunto

Partindo do pressuposto da $A C$ de que o comportamento ocorre em função de aspectos ambientais, compreende-se que, a depender das características do ambiente presente ou passado, os relacionamentos interpessoais serão diferenciados, considerando inclusive que cada membro dessas relações se constitui como ambiente um para o outro (Coleman \& Watson, 2000; O'Connor, 2010; Pianta \& Walsh, 1996; Skinner, 1953/1998; Weinfield et al., 2004). Portanto, eram esperadas diferenças nas razões apontadas pelos professores para aceitarem ou rejeitarem seus alunos, a depender de seu sexo e de seu nível escolar.

Os resultados alcançados evidenciam padrões de aceitação e rejeição nos anos escolares estudados que devem ser considerados ao se delinear estratégias de intervenção que visem a ampliar os fatores de proteção e reduzir os fatores de risco associados ao desenvolvimento de problemas relacionados ao estabelecimento de relacionamentos professor-aluno de baixa qualidade. 0 conhecimento relativo ao fato dos meninos serem mais rejeitados que as meninas, havendo inclusive a possibilidade de que isso se deva a percepções negativas das crianças do sexo masculino, mesmo quando apresentam comportamentos similares aos das do sexo feminino (Mullola et al., 2012; Siegle \& Reis, 1998), sugerem a importância de que os professores sejam informados sobre a existência dessas diferenças. Ao se conscientizarem delas, pode-se aumentar a probabilidade de que evitem tratamentos diferenciados que possam prejudicar o desenvolvimento dos alunos. Agindo de forma a possibilitar seu melhor desenvolvimento, aumentam-se as chances do comportamento do professor ser reforçado e mantido. 
No que se refere à presença de problemas de engajamento nos estudos e de indisciplina como razões apontados pelos professores para a rejeição das crianças, não apenas os professores devem ser conscientizados a respeito desses aspectos que influenciam seu julgamento acerca dos alunos, como também pode ser realizado com as próprias crianças um trabalho voltado a melhora desses comportamentos, com uma atenção maior aos problemas disciplinares, em alunos do Ensino Fundamental I e II, e aos problemas de engajamento, em estudantes do Ensino Fundamental II e Médio. Analogamente, ao se considerar os dados sobre os comportamentos de engajamento nos estudos e de disciplina como razões para aceitação, sugerem-se trabalhos com os professores e com os alunos que visem ao desenvolvimento ou à manutenção desses comportamentos, especificamente os relativos à disciplina, no $1^{\text {o }}$ ano do Ensino Fundamental, e ao engajamento acadêmico, em todos os níveis. Tratase de medidas fundamentais quando se considera que os alunos que possuem essas dificuldades são os que mais necessitam de um relacionamento com o professor que seja caracterizado pelo apoio sócio emocional (Baker, 2006; Burchinal et al., 2002; Fraser \& Walberg, 2005; Hamre \& Pianta, 2005; Meehan et al., 2003).

De forma geral, o presente trabalho possui um potencial de exercer um importante papel coerente com o objetivo da AC de lidar com os comportamentos de modo mais eficiente (Skinner, 1953/1998) a partir da compreensão das razões pelas quais as pessoas agem da maneira como agem e nas circunstâncias em que agem (Henklain \& Carmo, 2013). Os conhecimentos adquiridos no estudo podem trazer contribuições para que ocorram mudanças nos comportamentos vivenciados em ambiente escolar, gerando benefícios não apenas para o estabelecimento de relações mais reforçadoras para os docentes, como também para o desenvolvimento de um melhor repertório comportamental dos alunos. 
Referências 
Achenbach, T. M., \& Rescorla, L. A. (2001). Manual for the ASEBA School-Age Forms and Profiles [Manual]. Burlington, VT: University of Vermont, Research Center for Children, Youths, and Families.

Ahmed, W., Minnaert, A., van der Werf, G., \& Kuyper, H. (2010). Perceived social support and early adolescents' achievement: the mediational roles of motivational beliefs and emotions. Journal of Youth and Adolescence, 39(1), 36-46. doi: 10.1007/s10964-008-9367-7

Akkari, A. J. (2001). Desigualdades educativas estruturais no brasil: entre estado, privatização e descentralização. Educação \& Sociedade, 22(74), 163-189.

Azevedo, Â. S., Dias, P. C., Salgado, A., Guimarães, T., Lima, I., \& Barbosa, A. (2012). Relacionamento professor-aluno e auto-regulação da aprendizagem no 3ำ ciclo do ensino médio português. Paidéia (Ribeirão Preto), 22(52), 197-206.

Baker, J. A. (2006). Contributions of teacher-child relationships to positive school adjustment during elementary school. Journal of School Psychology, 44(3), 211-229.

Baker, P. H. (2005). Managing student behavior: how ready are teachers to meet the challenge?. American Secondary Education, 51-64. doi: 10.1037/1045-3830.23.1.3

Barbosa, A. J. G., Campos, R. A., \& Valentim, T. A. (2011). A diversidade em sala de aula e a relação professor-aluno. Estudos de Psicologia (Campinas), 28(4), 453-461.

Barrett, S., \& Heubeck, B. G. (2000). Relationships between school hassles and uplifts and anxiety and conduct problems in grades 3 and 4. Journal of Applied Developmental Psychology, 21(5), 537-554.

Batista, A. P., \& Weber, L. N. D. (2012). Estilos de liderança de professores: aplicando o modelo de estilos parentais. Psicologia Escolar e Educacional, 16(2), 299-307.

Baum, W. M. (2006). Compreender o behaviorismo: comportamento, cultura e evolução. Porto Alegre: ARTMED.

Bayliss, P., \& Avramidis, E. (2000). Mainstream teachers' attitudes towards the inclusion of students with special educational needs in the ordinary school. Trabalho apresentado no International Special Education Congress 2000, Manchester. Resumo retirado de http://www.isec2000.org.uk/abstracts/papers_b/bayliss3.htm.

Beaman, R., \& Wheldall, K. (2000). Teachers' use of approval and disapproval in the classroom. Educational Psychology, 20(4), 431-446. doi: 10.1080/713663753

Bergin, C., \& Bergin, D. (2009). Attachment in the classroom. Educational Psychology Review, 21(2), 141170. doi: 10.1007/s10648-009-9104-0 
Bierman, K. L. (2011). The promise and potential of studying the "invisible hand" of teacher influence on peer relations and student outcomes: a commentary. Journal of Applied Developmental Psychology, 32(5), 297-303.

Birch, S. H., \& Ladd, G. W. (1997). The teacher-child relationship and children's early school adjustment. Journal of School Psychology, 35(1), 61-79.

Birch, S. H., \& Ladd, G. W. (1998). Children's interpersonal behaviors and the teacher-child relationship. Developmental Psychology, 34(5), 934-946.

Bolsoni-Silva, A. T., Mariano, M. L., Loureiro, S. R., \& Bonaccorsi, C. (2013). Contexto escolar: práticas educativas do professor, comportamento e habilidades sociais infantis. Revista Semestral da Associação Brasileira de Psicologia Escolar e Educacional, 17(2), 259-269.

Botomé, S. P. (2001). Sobre a noção de comportamento. In H. P. de Moraes Feltes \& U. Zilles (Orgs.), Filosofia: diálogo de horizontes (pp. 687-708). Caxias do Sul: EDUCS

Breakwell, G. M., Hammond, S., Fife-Schaw, C., Smith, J. A. (2010). Métodos de pesquisa em psicologia (F. L. Elizade, Trad.). Porto Alegre: Artmed.

Brophy, J. E. (1983). Research on the self-fulfilling prophecy and teacher expectations. Journal of Educational Psychology, 75(5), 631-661. doi: 10.1037/0022-0663.75.5.631

Brophy, J. E., \& Good, T. L. (1970). Teachers' communication of differential expectations for children's classroom performance: some behavioral data. Journal of Educational Psychology, 61(5), 365-374.

Brown, J. L., Jones, S. M., LaRusso, M. D., \& Aber, J. L. (2010). Improving classroom quality: Teacher influences and experimental impacts of the 4rs program. Journal of Educational Psychology, 102(1), 153-167. doi: 10.1037/a0018160

Burchinal, M. R., Peisner-Feinberg, E., Pianta, R., \& Howes, C. (2002). Development of academic skills from preschool through second grade: family and classroom predictors of developmental trajectories. Journal of School Psychology, 40(5), 415-436.

Buyse, E., Verschueren, K., Doumen, S., Van Damme, J., \& Maes, F. (2008). Classroom problem behavior and teacher-child relationships in kindergarten: the moderating role of classroom climate. Journal of School Psychology, 46(4), 367-391.

Buyse, E., Verschueren, K., Verachtert, P., \& Van Damme, J. (2009). Predicting school adjustment in early elementary school: impact of teacher-child relationship quality and relational classroom climate. The Elementary School Journal, 110(2), 119-141. doi: 10.1086/605768

Bzuneck, J. A., \& Sales, K. F. S. (2011). Atribuições interpessoais pelo professor e sua relação com emoções e motivação do aluno. Psico USF, 16(3), 307-315. 
Carvalho, M. P. (2001). Mau aluno, boa aluna? Como as professoras avaliam meninos e meninas. Revista Estudos Feministas, 9(2), 554-574.

Carvalho, M. P. (2009). Gênero, raça e avaliação escolar: um estudo com alfabetizadoras. Cadernos de pesquisa, 39(138), 837-866.

Chen, X., Rubin, K. H., \& Li, B. (1995). Social and school adjustment of shy and aggressive children in China. Development and Psychopathology, 7(02), 337-349.

Clifford, M. M., \& Walster, E. (1973). The effect of physical attractiveness on teacher expectations. Sociology of Education, 46(2), 248-258.

Coie, J., Dodge, K. \& Coppotelli, H. (1982). Dimensions and types of social status: a cross-age perspective. Developmental Psychology, 18(4), 557-570.

Coleman, P., \& Watson, A. (2000). Infant attachment as a dynamic system. Human Development, 43(6), 295-313.

Connor, C. M., Piasta, S. B., Fishman, B., Glasney, S., Schatschneider, C., Crowe, E., ... Morrison, F. J. (2009). Individualizing student instruction precisely: effects of child $\times$ instruction interactions on first graders' literacy development. Child development, 80(1), 77-100. doi: 10.1111/j.14678624.2008.01247.x

Cook, B. G. (2001). A comparison of teachers' attitudes toward their included students with mild and severe disabilities. The Journal of Special Education, 34(4), 203-213.

Cook, B. G. (2004). Inclusive teachers' attitudes toward their students with disabilities: a replication and extension. The Elementary School Journal, 104(4), 307-320.

Cook, B. G., \& Cameron, D. L. (2010). Inclusive teachers' concern and rejection toward their students investigating the validity of ratings and comparing student groups. Remedial and Special Education, 31(2), 67-76.

Cook, B. G., Cameron, D. L., \& Tankersley, M. (2007). Inclusive teachers' attitudinal ratings of their students with disabilities. The Journal of Special Education, 40(4), 230-238.

Cook, B. G., Tankersley, M., Cook, L., \& Landrum, T. J. (2000). Teachers' attitudes toward their included students with disabilities. Exceptional Children, 67(1), 115-135.

Corno, L. Y. N. (2008). On teaching adaptively. Educational Psychologist, 43(3), 161-173.

D’Oliveira, M. H. (1998). Analisando a relação professor-aluno: do planejamento à sala de aula. São Paulo: CLR-Balieiros.

Da Silva, C. A., Barros, F., Halpern, S. C., \& Da Silva, L. A. (1999). Meninas bem-comportadas, boas alunas; meninos inteligentes, indisciplinados. Cadernos de Pesquisa, 107, 207-225. 
De Boer, A., Pijl, S. J., \& Minnaert, A. (2011). Regular primary school teachers' attitudes towards inclusive education: a review of the literature. International Journal of Inclusive Education, 15(3), 331-353. doi:10.1080/13603110903030089

Dee, T. S. (2005). A teacher like me: does race, ethnicity, or gender matter?. The American economic review, 95(2), 158-165.

Dee, T. S. (2007). Teachers and the gender gaps in student achievement. Journal of Human Resources, 42(3), 528-554.

Del Prette, Z. A. P., \& Del Prette, A. (1999). Psicologia das habilidades sociais: terapia e educação. Petrópolis: Vozes.

Del Prette, Z. A. P., \& Del Prette, A. (2001). Psicologia das relações interpessoais: vivências para o trabalho em grupo. Petrópolis: Vozes.

Del Prette, Z. A. P., \& Del, Prette, A. (2006). Treinamento de habilidades sociais na escola: o método vivencial e a participação do professor. In M. Bandeira, Z. A. P. Del Prette \& A. Del Prette (Orgs.), Estudos sobre habilidades sociais e relacionamento interpessoal (pp. 143-160). São Paulo: Casa do Psicólogo.

Del Prette, Z. A. P., Paiva, M. L. M. F., \& Del Prette, A. (2005). Contribuições do referencial das habilidades sociais para uma abordagem sistêmica na compreensão do processo de ensinoaprendizagem. Interações, 10(20), 57-72.

DeRosier, M. E., Kupersmidt, J. B., \& Patters, C. J. (1994). Children's academic and behavioral adjustment as a function of the chronicity and proximity of peer rejection. Child Development, 65(6), 17991813.

DiLalla, L. F., Marcus, J. L., \& Wright-Phillips, M. V. (2004). Longitudinal effects of preschool behavioral styles on early adolescent school performance. Journal of School Psychology, 42(5), 385-401.

Dittrich, A., Melo, C. M., Moreira, M. B., \& Martone, R. C. (2013). O modelo de seleção pelas consequências: o nível cultural. In M. B. Moreira (Org.), Comportamento e Práticas Culturais (pp. 45-55). Brasília: Instituto Walden4.

Donahoe, J. W. (1993). The unconventional wisdom of B. F. Skinner: the analysis-interpretation distinction. Journal of the Experimental Analysis of Behavior, 60(2), 453-456.

Donohue, K. M., Perry, K. E., \& Weinstein, R. S. (2003). Teacher's classroom practices and children's rejection by their peers. Journal of Applied Developmental Psychology, 24(1), 91-118.

Dusek, J. B., \& Joseph, G. (1983). The bases of teacher expectancies: a meta-analysis. Journal of Educational Psychology, 75(3), 327. 
Else-Quest, N. M., Hyde, J. S., Goldsmith, H. H., \& Van Hulle, C. A. (2006). Gender differences in temperament: a meta-analysis. Psychological Bulletin, 132(1), 33-72. doi: 10.1037/00332909.132.1.33

Emmer, E. T., \& Stough, L. M. (2001). Classroom management: a critical part of educational psychology, with implications for teacher education. Educational Psychologist, 36(2), 103-112.

Farmer, T. W., Lines, M. M., \& Hamm, J. V. (2011). Revealing the invisible hand: the role of teachers in children's peer experiences. Journal of Applied Developmental Psychology, 32(5), 247-256.

Fontaine, N. S., Torre, L. D., Grafwallner, R., \& Underhill, B. (2006). Increasing quality in early care and learning environments. Early Child Development and Care, 176(2), 157-169.

Fragoso, F. M. R. A., \& Casal, J. (2012) Representações sociais dos educadores de infância e a inclusão de alunos com necessidades educativas especiais. Revista Brasileira de Educação Especial, 18(3), 527-546.

Fraser, B. J., \& Walberg, H. J. (2005). Research on teacher-student relationships and learning environments: context, retrospect and prospect. International Journal of Educational Research, 43(1), 103-109.

Fredricks, J. A., Blumenfeld, P. C., \& Paris. A. H. (2004). School engagement: potential of the concept, state of the evidence. Review of Educational Research, 74(1), 59-109. doi: $10.3102 / 00346543074001059$

Furrer, C., \& Skinner, E. (2003). Sense of relatedness as a factor in children's academic engagement and performance. Journal of Educational Psychology, 95(1), 148-162. doi: 10.1037/0022-0663.95.1.148

Galanaki, E. P., \& Vassilopoulou, H. D. (2007). Teachers and children's loneliness: a review of the literature and educational implications. European Journal of Psychology of Education, 22(4), 455475.

Gardinal, E. C., \& Marturano, E. M. (2007). Meninos e meninas na Educação Infantil: associação entre comportamento e desempenho. Psicologia em Estudo, 12(3), 541-551.

Gazelle, H. (2006). Class climate moderates peer relations and emotional adjustment in children with an early history of anxious solitude: a child x environment model. Developmental Psychology, 42(6), 1179-1192.

Gest, S. D., \& Rodkin, P. C. (2011). Teaching practices and elementary classroom peer ecologies. Journal of Applied Developmental Psychology, 32(5), 288-296.

Gomes, C., \& Barbosa, A. J. G. (2006). Inclusão escolar do portador de paralisia cerebral: atitudes de professores do ensino fundamental. Revista Brasileira de Educação Especial, 12(1), 85-100. 
Good, T. L., \& Nichols, S. L. (2001). Expectancy effects in the classroom: a special focus on improving the reading performance of minority students in first-grade classrooms. Educational Psychologist, 36(2), 113-126.

Gregory, A., \& Weinstein, R. S. (2004). Connection and regulation at home and in school: predicting growth in achievement for adolescents. Journal of Adolescent Research, 19(4), 405-427. doi: $10.1177 / 0743558403258859$

Hall, A. H., \& Cassidy, D. J. (2002). An assessment of the North Carolina school-age child care accreditation initiative. Journal of Research in Childhood Education, 17(1), 84-96.

Hamre, B. K., \& Pianta, R. C. (2001). Early teacher-child relationships and the trajectory of children's school outcomes through eighth grade. Child development, 72(2), 625-638.

Hamre, B. K., \& Pianta, R. C. (2004). Self-reported depression in nonfamilial caregivers: prevalence and associations with caregiver behavior in child-care settings. Early Childhood Research Quarterly, 19(2), 297-318.

Hamre, B. K., \& Pianta, R. C. (2005). Can instructional and emotional support in the first-grade classroom make a difference for children at risk of school failure?. Child development, 76(5), 949-967.

Hamre, B. K., \& Pianta, R. C. (2006). Student-teacher relationships. In G. G. Bear \& K. M. Minke (Eds.), Children's Needs III: Development, Prevention, and Intervention (pp. 59-71).Washington, DC: National Association of School Psychologists.

Hamre, B. K., Pianta, R. C., Downer, J. T., \& Mashburn, A. J. (2008). Teachers' perceptions of conflict with young students: looking beyond problem behaviors. Social Development, 17(1), 115-136.

Harter, S. (1996). Teacher and classmate influences on scholastic motivation, self-esteem, and level of voice in adolescents. In J. Juvonen \& K. Wentzel (Eds.), Social motivation: understanding children's school adjustment (pp. 11-42). New York: Cambridge University Press.

Hearns, S. (1998). Is child-related training or general education a better predictor of good quality care?. Early Child Development and Care, 141(1), 31-39. doi: 10.1080/0300443981410103

Heller, M. S., \& White, M. A. (1975). Rates of teacher verbal approval and disapproval to higher and lower ability classes. Journal of Educational Psychology, 67(6), 796-800. doi: 10.1037/00220663.67.6.796

Henklain, M. H. O., \& Carmo, S. D. S. (2013). Contribuições da análise do comportamento à educação: um convite ao diálogo. Cadernos de Pesquisa, 43(149), 704-723.

Henricsson, L., \& Rydell, A. M. (2004). Elementary school children with behavior problems: teacher-child relations and self-perception. A prospective study. Merrill-Palmer Quarterly, 50(2), 111-138. 
Howes, C., \& Ritchie, S. (1999). Attachment organizations in children with difficult life circumstances. Development and Psychopathology, 11(02), 251-268.

Howes, C., Hamilton, C. E., \& Matheson, C. C. (1994). Children's relationships with peers: differential associations with aspects of the teacher-child relationship. Child Development, 65(1), 253-263.

Hübner, M. M. C. (2005). O Skinner que poucos conhecem: contribuições do autor para um mundo melhor, com ênfase na relação professor-aluno. Momento do Professor: Revista de Educação Continuada, 2(4), 44-49.

Hughes, J. N., \& Chen, Q. (2011). Reciprocal effects of student-teacher and student-peer relatedness: effects on academic self efficacy. Journal of applied Developmental Psychology, 32(5), 278-287.

Hughes, J. N., \& Kwok, O. M. (2006). Classroom engagement mediates the effect of teacher-student support on elementary students' peer acceptance: a prospective analysis. Journal of School Psychology, 43(6), 465-480.

Hughes, J. N., \& Kwok, O. M. (2007). Influence of student-teacher and parent-teacher relationships on lower achieving readers' engagement and achievement in the primary grades. Journal of Educational Psychology, 99(1), 39-51. doi: 10.1037/0022-0663.99.1.39

Hughes, J. N., Luo, W., Kwok, O. M., \& Loyd, L. K. (2008). Teacher-student support, effortful engagement, and achievement: a 3-year longitudinal study. Journal of Educational Psychology, 100(1), 1-14. doi: 10.1037/0022-0663.100.1.1

Irvine, J. J. (1986). Teacher-student interactions: effects of student race, sex, and grade level. Journal of Educational Psychology, 78(1), 14-21. doi: 10.1037/0022-0663.78.1.14

Jackson, P. W., Silberman, M. L., \& Wolfson, B. J. (1969). Signs of personal involvement in teachers' descriptions of their students. Journal of Educational Psychology, 60(1), 22-27. doi: $10.1037 / \mathrm{h} 0026690$

Janney, D. M., Umbreit, J., Ferro, J. B., Liaupsin, C. J., \& Lane, K. L. (2013). The effect of the extinction procedure in function-based intervention. Journal of Positive Behavior Interventions, 15(2), 113123.

Jerome, E. M., Hamre, B. K., \& Pianta, R. C. (2008). Teacher-child relationships from kindergarten to sixth grade: early childhood predictors of teacher-perceived conflict and closeness. Social Development, 18(4), 915-945.

Kerr, M. (2001). Culture as a context for temperament: suggestions from the life courses of shy Swedes and Americans. In T. D. Wachs \& G. A. Kohnstamm (Eds.), Temperament in context (pp. 118-129). Mahwah, NJ: Lawrence Erlbaum Associates. 
Kerr, M., Lambert, W. W., \& Bem, D. J. (1996). Life course sequelae of childhood shyness in Sweden: comparison with the United States. Developmental Psychology, 32(6), 1100-1105. doi: 10.1037/0012-1649.32.6.1100

Kesner, J. E. (2000). Teacher characteristics and the quality of child-teacher relationships. Journal of School Psychology, 38(2), 133-149.

Kos, J. M., Richdale, A. L., \& Hay, D. A. (2006). Children with Attention Deficit Hyperactivity Disorder and their teachers: a review of the literature. International Journal of Disability, Development and Education, 53(2), 147-160.

Kosir, K., \& Tement, S. (2013). Teacher-student relationship and academic achievement: a cross-lagged longitudinal study on three different age groups. European Journal of Psychology of Education, 29(3), 409-428. doi: 10.1007/s10212-013-0205-2

Kubo, O. M., \& Botomé, S. P. (2001). Ensino-aprendizagem: uma interação entre dois processos comportamentais. Interação em Psicologia, 5(1), 131-171.

Kuester, V. M. (2000). 10 Years on: have teacher attitudes toward the inclusion of students with disabilities changed?. Trabalho apresentado no International Special Education Congress 2000, Manchester. Resumo retirado de http://www.isec2000.org.uk/abstracts/papers_k/kuester_1.htm

Kwok, O. M., Hughes, J. N., \& Luo, W. (2007). Role of resilient personality on lower achieving first grade students' current and future achievement. Journal of School Psychology, 45(1), 61-82.

Ladd, G. W., Birch, S. H., \& Buhs, E. S. (1999). Children's social and scholastic lives in kindergarten: related spheres of influence?. Child Development, 70(6), 1373-1400.

Laet, S. D., Doumen, S., Vervoort, E., Colpin, H., Leeuwen, K. V., Goossens, L., \& Verschueren, K. (2014). Transactional links between teacher-child relationship quality and perceived versus sociometric popularity: a three-wave longitudinal study. Child Development, 85(4), 1647-1662.

LaFrance, M., Hecht, M. A., \& Paluck, E. L. (2003). The contingent smile: a meta-analysis of sex differences in smiling. Psychological Bulletin, 129(2), 305-334. doi: 10.1037/0033-2909.129.2.305

Lago-Delello, E. (1998). Classroom dynamics and the development of serious emotional disturbance. Exceptional Children, 64(4), 479-492.

Lamas, K. C. A., Freitas, E. R., \& Barbosa, A. J. G. (2013). Bullying e relação professor-aluno: percepções de estudantes do Ensino Fundamental. Psico, 44(2), 263-272.

Landis, J. R., \& Koch, G. G. (1977). The measurement of observer agreement for categorical data. Biometrics, 33, 159-174. 
Lane, K., Smither, R., Huseman, R., Guffey, J., \& Fox, J. (2007). A function-based intervention to decrease disruptive behavior and increase academic engagement. Journal Of Early \& Intensive Behavior Intervention, 3-4(4-1), 348-364.

LaPointe, J. M. (2003). Teacher-student conflict and misbehavior: toward a model of the extended symmetrical escalation. Journal of Classroom Interaction, 38(2), 11-19.

LaVoie, J. C., \& Adams, G. R. (1974). Teacher expectancy and its relation to physical and interpersonal characteristics of the child. Alberta journal of educational research.

Li, Q. (1999). Teachers' beliefs and gender differences in mathematics: a review. Educational Research, 41(1), 63-76.

López, F. (2004). Problemas afetivos e de conduta na sala de aula. In C. Coll, A. Marchesi \& J. Palacios (Orgs.), Desenvolvimento psicológico e educação: transtornos do desenvolvimento e necessidades educativas especiais (pp. 113-128). Porto Alegre: Artmed.

Luckner, A. E., \& Pianta, R. C. (2011). Teacher-student interactions in fifth grade classrooms: relations with children's peer behavior. Journal of Applied Developmental Psychology, 32(5), 257-266.

Lynch, M., \& Cicchetti, D. (1997). Children's relationships with adults and peers: an examination of elementary and junior high school students. Journal of School Psychology, 35(1), 81-99.

Maia, A. C. B., Navarro, C., \& Maia, A. F. (2011). Relações entre gênero e escola no discurso de professoras do ensino fundamental. Psicologia da Educação, 32, 25-46.

Maia, R. C. C., Soares, A. B., \& Victoria, M. S. D. (2009). Um estudo com professores da educação infantil e do ensino fundamental sobre suas habilidades sociais e inteligência geral. Estudos e Pesquisas em Psicologia, 9(2), 464-479.

Maulana, R., Opdenakker, M. C., \& Bosker, R. (2013). Teacher-student interpersonal relationships do change and affect academic motivation: a multilevel growth curve modelling. British Journal of Educational Psychology, 84, 459-482. doi:10.1111/bjep.12031

Mantzicopoulos, P. (2005). Conflictual relationships between kindergarten children and their teachers: associations with child and classroom context variables. Journal of School Psychology, 43(5), 425442.

Marinho, M. L. (2003). Comportamento anti-social infantil: questões teóricas e de pesquisa. In A. Del Prette \& Z. Del Prette (Orgs.), Habilidades sociais, desenvolvimento e aprendizagem: questões conceituais, avaliação e intervenção (pp. 61-81). Campinas, SP: Alínea.

Martinelli, S. D. C., \& Schiavoni, A. (2009). Percepção do aluno sobre sua interação com o professor e status sociométrico. Estudos de Psicologia (Campinas), 26(3), 327-336. 
Mash, E. J., \& Barkley, R. A. (1996). Child psychopathology. New York: Guilford Press. Retirado de http://books.google.com.br/books?id=T3zarJqFDbwC\&pg=PA3\&hl=pt-

BR\&source $=$ gbs_toc_r\&cad $=4 \# v=$ onepage $\& q \& f=$ false

Mashburn, A. J., Hamre, B. K., Downer, J. T., \& Pianta, R. C. (2006). Teacher and classroom characteristics associated with teachers' ratings of prekindergartners' relationships and behaviors. Journal of Psychoeducational Assessment, 24(4), 367-380.

Matteucci, M. C. (2007). Teachers facing school failure: the social valorization of effort in the school context. Social Psychology of Education, 10(1), 29-53.

Meehan, B. T., Hughes, J. N., \& Cavell, T. A. (2003). Teacher-student relationships as compensatory resources for aggressive children. Child Development, 74(4), 1145-1157. doi: 10.1111/14678624.00598

Meireles, F. M. (2009). As relações entre as medidas de habilidades sociais do professor do Ensino Fundamental II e seu desempenho social em sala de aula. Revista Visões, 6(1). Retirado de http://www.fsma.edu.br/visoes/principal.html.

Melo, C. M., Dittrich, A., Moreira, M. B., \& Martone, R. C. (2013a). O modelo de seleção pelas consequências: o nível filogenético. In M. B. Moreira (Org.), Comportamento e Práticas Culturais (pp. 24-34). Brasília: Instituto Walden4.

Melo, C. M., Dittrich, A., Moreira, M. B., \& Martone, R. C. (2013b). O modelo de seleção pelas consequências: o nível ontogenético. In M. B. Moreira (Org.), Comportamento e Práticas Culturais (pp. 35-44). Brasília: Instituto Walden4.

Mendes, E. G., \& Lourenço, G. F. (2009). Viés de gênero na notificação de alunos com necessidades educacionais especiais. Revista Brasileira de Educação Especial, 15(3), 417-430.

Mendez, J. L., McDermott, P., \& Fantuzzo, J. (2002). Identifying and promoting social competence with African American preschool children: developmental and contextual considerations. Psychology in the Schools, 39(1), 111-123.

Mercer, S. H., \& DeRosier, M. E. (2008). Teacher preference, peer rejection, and student aggression: a prospective study of transactional influence and independent contributions to emotional adjustment and grades. Journal of School Psychology, 46(6), 661-685.

Merritt, E. G., Wanless, S. B., Rimm-Kaufman, S. E., Cameron, C., \& Peugh, J. L. (2012). The contribution of teachers' emotional support to children's social behaviors and self-regulatory skills in first grade. School Psychology Review, 41(2), 141-159.

Moreira, M. B., \& Medeiros, C. A. (2007). Princípios básicos de análise do comportamento. São Paulo: Artmed. 
Muller, C. (2001). The role of caring in the teacher-student relationship for at-risk students. Sociological Inquiry, 71(2), 241-255.

Mullola, S., Ravaja, N., Lipsanen, J., Alatupa, S., Hintsanen, M., Jokela, M., \& Keltikangas-Järvinen, L. (2012). Gender differences in teachers' perceptions of students' temperament, educational competence, and teachability. British Journal of Educational Psychology, 82(2), 185-206. doi: 10.1111/j.2044-8279.2010.02017.x

Murray, C., \& Greenberg, M. T. (2000). Relationships with teachers and bonds with school: social emotional adjustment correlates for children with and without disabilities. Psychology in the Schools, 38(1), 25-41. doi: 10.1002/1520-6807(200101)38:1<25::AID-PITS4>3.0.CO;2-C

Murray, C., \& Murray, K. M. (2004). Child level correlates of teacher-student relationships: an examination of demographic characteristics, academic orientations, and behavioral orientations. Psychology in the Schools, 41(7), 751-762.

Murray, C., Murray, K. M., \& Waas, G. A. (2008). Child and teacher reports of teacher-student relationships: concordance of perspectives and associations with school adjustment in urban kindergarten classrooms. Journal of Applied Developmental Psychology, 29(1), 49-61.

Murray-Harvey, R., \& Slee, P. T. (2010). School and home relationships and their impact on school bullying. School Psychology International, 31(3), 271-295.

Nesdale, D., \& Pickering, K. (2006). Teachers' reactions to children's aggression. Social Development, 15(1), 109-127.

Niehaus, K., Moritz Rudasill, K., \& Rakes, C. R. (2012). A longitudinal study of school connectedness and academic outcomes across sixth grade. Journal of School Psychology, 50, 443-460.

Nurmi, J. E. (2012). Students' characteristics and teacher-child relationships in instruction: a metaanalysis. Educational Research Review, 7(3), 177-197.

O'Connor, E. (2010). Teacher-child relationships as dynamic systems. Journal of School Psychology, 48(3), 187-218. doi:10.1016/j.jsp.2010.01.001

O'Connor, E., \& McCartney, K. (2006). Testing associations between mother-child and teacher-child relationships. Journal of Educational Psychology, 26(5), 301-326.

Osterman, K. F. (2000). Students' need for belonging in the school community. Review of educational research, 70(3), 323-367.

Osti, A., \& Martinelli, S. C. (2014). Desempenho escolar: análise comparativa em função do sexo e percepção dos estudantes. Educação e Pesquisa, 40(1), 49-59.

Patrick, H., Ryan, A. M., \& Kaplan, A. (2007). Early adolescents' perceptions of the classroom social environment, motivational beliefs, and engagement. Journal of Educational Psychology, 99(1), 83. 
Petrucci, G. W., Borsa, J. C., Barbosa, A. J. G., \& Koller, S. H. (2014). Adaptação cultural e evidências de validade da Escala de Relacionamento Professor-Aluno. Avaliação Psicológica, 13(1), 133-142.

Pianta, R. C., \& Nimetz, S. (1991). Relationship between children and teachers: associations with classroom and home behavior. Journal of Applied Developmental Psychology, 12(3), 379-393. doi: 10.1016/0193-3973(91)90007-Q

Pianta, R. C., \& Steinberg, M. (1992). Teacher-child relationships and the process of adjusting to school. New Directions for Child and Adolescent Development, 1992(57), 61-80.

Pianta, R. C., \& Walsh, D. J. (1996). High-risk children in schools: constructing sustaining relationships. New York: Routledge.

Pianta, R. C., Howes, C., Burchinal, M., Bryant, D., Clifford, R., Early, C., \& Barbarin, O. (2005). Features of pre-kindergarten programs, classrooms, and teachers: do they predict observed classroom quality and child-teacher interactions?. Applied Developmental Science, 9(3), 144-159.

Pianta, R. C., LaParo, K. M., \& Hamre, B. K. (2008). Classroom Assessment Scoring System. Baltimore: Paul H. Brookes.

Picado, J. R., \& de Rose, T. M. S. (2009). Acompanhamento de pré-escolares agressivos: adaptação na escola e relação professor-aluno. Psicologia: Ciência e Profissão, 29(1), 132-145.

Reis, R. M. C. (2005). A pré-escola na visão de crianças de 1ạ série. Psicologia da Educação, 20, 55-75.

Resnick, M. D., Bearman, P. S., Blum, R. W., Bauman, K. E., Harris, K. M., Jones, J., ... Udry, J. R. (1997). Protecting adolescents from harm: findings from the national longitudinal study of adolescent health. Journal of the American Medical Association, 278(10), 823-832. doi:10.1001/jama.1997.03550100049038

Reyna, C., \& Weiner, B. (2001). Justice and utility in the classroom: an attributional analysis of the goals of teachers' punishment and intervention strategies. Journal of Educational Psychology, 93(2), 309319. doi: 10.1037/0022-0663.93.2.309

Ribeiro, M. L. (2010). A afetividade na relação educativa. Estudos de Psicologia (Campinas), 27(3), 403412.

Rodrigues, M. E. (2005). A contribuição do Behaviorismo Radical para a formação de professores-uma análise a partir das dissertações e teses no período de 1970 a 2002 (Tese de Doutorado). Pontifícia Universidade Católica de São Paulo, São Paulo.

Roehrs, H., Maftum, M. A., \& Zagonel, I. P. S. (2010). Adolescência na percepção de professores do ensino fundamental. Revista da Escola de Enfermagem da USP, 44(2), 421-428.

Rolland, R. G. (2012). Synthesizing the evidence on classroom goal structures in middle and secondary schools a meta-analysis and narrative review. Review of Educational Research, 82(4), 396-435. 
Roorda, D. L., Koomen, H. M., Spilt, J. L., \& Oort, F. J. (2011). The influence of affective teacher-student relationships on students' school engagement and achievement - a meta-analytic approach. Review of Educational Research, 81(4), 493-529.

Rotter, G. S. (1967). The effect of sex identification upon teacher evaluation of pupils. Trabalho apresentado no encontro da Eastern Psychological Association, Boston, Retirado de http://www.eric.ed.gov.

Rudasill, K. M., \& Rimm-Kaufman, S. E. (2009). Teacher-child relationship quality: the roles of child temperament and teacher-child interactions. Early Childhood Research Quarterly, 24(2), 107-120.

Rudasill, K. M., Rimm-Kaufman, S., Justice, L., \& Pence, K. (2006). Temperament and language skills as predictors of teacher-child relationship quality in preschool. Early Education and Development, 17(2), 271-291.

Runions, K. C., Vitaro, F. Cross, D., Shaw, T., Hall, M. \& Boivin, M. (2014). Teacher-child relationship, parenting, and growth in likelihood and severity of physical aggression in the early school years. Merrill-Palmer Quarterly, 60(3), 274-301. doi: 10.1353/mpq.2014.0018

Ryan, R. M., Stiller, J. D., \& Lynch, J. H. (1994). Representations of relationships to teachers, parents, and friends as predictors of academic motivation and self-esteem. The Journal of Early Adolescence, 14(2), 226-249.

Saft, E. W., \& Pianta, R. C. (2001). Teachers' perceptions of their relationships with students: effects of child age, gender, and ethnicity of teachers and children. School Psychology Quarterly, 16(2), 125141. doi: $10.1521 /$ scpq.16.2.125.18698

Sanson, A. V., Smart, D. F., Prior, M., Oberklaid, F., \& Pedlow, R. (1994). The structure of temperament from age 3 to 7 years: age, sex, and sociodemographic influences. Merrill-Palmer Quarterly, 40(2), 233-252.

Shin, Y., \& Kim, H. Y. (2008). Peer Victimization in Korean preschool children - the effects of child characteristics, parenting behaviours and teacher-child relationships. School Psychology International, 29(5), 590-605.

Sidman, M. (2009). Coerção e suas implicações (M. A. Andery, \& T. A. Sério, Trads.). São Paulo: Editora Livro Pleno. (Original publicado em 1989)

Siegle, D., \& Reis, S. M. (1998). Gender differences in teacher and student perceptions of gifted students' ability and effort. Gifted Child Quarterly, 42(1), 39-47.

Silberman, M. (1969). Behavioral expression of teachers' attitudes toward elementary school students. Journal of Educational Psychology, 60(5), 402-407. 
Silvares, E. F. M., \& Melo, M. H. S. (2010). Rejeição Infantil: o papel dos colegas de escola e professores. In M. P, R. de Souza. (Org.), Ouvindo crianças na escola (pp 102-112). Itatiba: Casa do Psicólogo.

Silver, R. B., Measelle, J. R., Armstrong, J. M., \& Essex, M. J. (2005). Trajectories of classroom externalizing behavior: contributions of child characteristics, family characteristics, and the teacher-child relationship during the school transition. Journal of School Psychology, 43(1), 39-60.

Skinner, B. F. (1975). Tecnologia do Ensino (R. Azzi, Trad.). São Paulo: EDUSP. (Original publicado em 1972).

Skinner, B. F. (1990). Can psychology be a science of mind?. American Psychologist, 45(1), 1206-1210.

Skinner, B. F. (1998). Ciência e Comportamento Humano (10a ed.). São Paulo: Martins Fontes. (Original publicado em 1953)

Skinner, B. F. (2005). Questões recentes em Análise Comportamental. São Paulo: Papirus. (Original publicado em 1989)

Skinner, E., Furrer, C., Marchand, G., \& Kindermann, T. (2008). Engagement and disaffection in the classroom: part of a larger motivational dynamic?. Journal of Educational Psychology, 100(4), 765781. doi: $10.1037 / \mathrm{a} 0012840$

Soares, T. M., Fernandes, N. D. S., Ferraz, M. S. B., \& Riani, J. D. L. R. D. (2010). Teacher's expectation and students' performance. Psicologia: Teoria e Pesquisa, 26(1), 157-170.

Soares, A. B., Naiff, L. A. M., Fonseca, L. B. D., Cardozo, A., \& Baldez, M. D. O. (2009). Estudo comparativo de habilidades sociais e variáveis sociodemográficas de professores. Psicologia: Teoria e Prática, 11(1), 35-49.

Stancic, Z. (2000). Teacher's attitudes toward teaching as a determinant of their readiness for additional professional special education. Trabalho apresentado no International Special Education Congress 2000, Manchester. Resumo retirado de http://www.isec2000.org.uk/abstracts/papers_s/stancic_1.htm

Stroet, K., Opdenakker, M. C., \& Minnaert, A. (2012). Effects of need supportive teaching on early adolescents' motivation and engagement: a review of the literature. Educational Research Review, 9, 65-87.

Stuhlman, M. W., \& Pianta, R. C. (2002). Teachers' narratives about their relationships with children: associations with behavior in classrooms. School Psychology Review, 31(2), 148-163.

Tacca, M. C. V. R., \& Branco, A. U. (2008). Processos de significação na relação professor-alunos: uma perspectiva sociocultural construtivista. Estudos de Psicologia, 13(1), 39-48. 
Tenenbaum, H. R., \& Ruck, M. D. (2007). Are teachers' expectations different for racial minority than for European American students? A meta-analysis. Journal of Educational Psychology, 99(2), 253-273. doi: 10.1037/0022-0663.99.2.253

Thijs, J., \& Verkuyten, M. (2009). Students' anticipated situational engagement: the roles of teacher behavior, personal engagement, and gender. The Journal of Genetic Psychology, 170(3), 268-286.

Todorov, J. C. (1985). O conceito de contingência tríplice na análise do comportamento humano. Psicologia: Teoria e Pesquisa, 1(1), 75-88.

Tourinho, E. Z. (1999). Estudos conceituais na análise do comportamento. Temas em Psicologia, 7(3), 213-222.

Tourinho, E. Z. (2003). A produção de conhecimento em psicologia: a Análise do Comportamento. Psicologia: Ciência e Profissão, 23(3), 30-41.

Troop-Gordon, W., \& Kopp, J. (2011). Teacher-child relationship quality and children's peer victimization and aggressive behavior in late childhood. Social Development, 20(3), 536-561.

Ulrich, E., \& Kubo, O. M. (2004). Aprendendo com parcerias entre professores e alunos. Revista Psicologia, 4(2), 171-176.

Viecili, J., \& Medeiros, J. G. (2002). A coerção e suas implicações na relação professor-aluno. PsicoUSF, 7(2), 229-238.

Weinfield, N. S., Whaley, G. J. L., \& Egeland, B. (2004). Continuity, discontinuity, and coherence in attachment from infancy to late adolescence: sequelae of organization and disorganization. Attachment \& Human Development, 6(1), 73-97.

Wentzel, K. R. (1998). Social relationships and motivation in middle school: the role of parents, teachers, and peers. Journal of Educational Psychology, 90(2), 202-209. doi: 10.1037/0022-0663.90.2.202

Wentzel, K. R. (2003). Sociometric status and adjustment in middle school: a longitudinal study. Journal of Early Adolescence, 23(1), 5-28. doi:10.1177/0272431602239128

Wesely, P. M. (2009). The language learning motivation of early adolescent French immersion graduates. Foreign Language Annals, 42(2), 270-286.

Wilson, H. K., Pianta, R. C., \& Stuhlman, M. (2007). Typical classroom experiences in first grade: the role of classroom climate and functional risk in the development of social competencies. The Elementary School Journal, 108(2), 81-96.

Wubbels, T. (2007). Classroom management around the world. In M. Hayden, J. Levy, \& J. J. Thompson (Eds.), The Sage handbook of research in international education (pp. 267-280). London, England: Sage. Retirado de http://books.google.com.br/books?id=usbKODJZSKsC\&pg=PA2\&lpg=PA2\&dq=The+Sage+handboo 
k+of+research+in+international+education\&source=bl\&ots=PY87giOMvx\&sig=s3K97Uc4K4_wkW VRG18Gy7GF6zM\&hl=pt-

BR\&sa=X\&ei=|8fKUpCqH83ksASqz|GIDQ\&ved=0CFcQ6AEwBA\#v=onepage\&q=The\%20Sage\%20ha ndbook\%20of\%20research\%20in\%20international\%20education\&f=false.

Zanotto, M. L. B. (2000). Formação de professores: a contribuição da análise do comportamento. São Paulo, SP: EDUC.

Zhou, Q., Lengua, L. J., \& Wang, Y. (2009). The relations of temperament reactivity and effortful control to children's adjustment problems in China and the United States. Developmental Psychology, 45(3), 724-739. doi: 10.1037/a0013776 
Apêndices 


\section{APÊNDICE A - Primeira versão do questionário}

Prezado(a) professor(a),

Este estudo tem por objetivo investigar como as características dos alunos influenciam o relacionamento com seus professores, de modo que sua participação é de grande importância. Portanto, obrigada por se disponibilizar para preencher este questionário.

Este questionário é constituído por duas partes. Na primeira (itens " $a$ " a " $f$ "), são solicitadas algumas informações sobre você. Na segunda (itens "g" a "l"), há questões relacionadas com seus alunos. Lembre-se que as informações fornecidas são sigilosas, que você não está sendo avaliado e que não há respostas corretas ou incorretas. Leve o tempo que precisar para preencher o questionário.

Por favor, leia com atenção cada dado solicitado, preenchendo com cuidado e buscando dar respostas verdadeiras, de modo a contribuir com a validade do estudo.

Obrigada!

a) Sexo: F( ) M( )

b) Idade:

c) Tempo de profissão:

d) Tempo em que leciona nesta escola:

e) Turma em que leciona:

f) Tempo em que leciona nesta turma:

g) Se você pudesse manter três alunos na sua sala por mais um ano, quem você escolheria? Aluno 1:

Aluno 2:

Aluno 3:

h) Explique o principal motivo para a escolha de cada aluno citado na questão "g". Aluno 1:

Aluno 2:

Aluno 3:

i) Se houver, explique os motivos secundários da escolha de cada aluno citado na questão " $g$ ". Aluno 1:

Aluno 2:

Aluno 3:

j) Se sua classe tivesse que ser reduzida em três alunos, quem você indicaria?

Aluno 1:

Aluno 2:

Aluno 3:

k) Explique o principal motivo para a escolha de cada aluno citado na questão "j".

Aluno 1:

Aluno 2:

Aluno 3:

I) Se houver, explique os motivos secundários da escolha de cada aluno citado na questão "j".

Aluno 1:

Aluno 2:

Aluno 3: 


\section{APÊNDICE B - Questionário definitivo}

Prezado(a) professor(a),

Este estudo tem por objetivo investigar como as características dos alunos influenciam o relacionamento com seus professores, sendo sua participação de grande importância. Portanto, obrigada por se disponibilizar para preencher este questionário.

Lembre-se que as informações fornecidas são sigilosas e anônimas, não interferindo em seu trabalho, que você não está sendo avaliado e que não há respostas corretas ou incorretas.

O questionário é constituído por duas partes. Na primeira (itens "a" a "j"), são solicitadas algumas informações sobre você. Na segunda (itens "I" a "VI"), há questões relacionadas com seus alunos.

Por favor, leia com atenção cada dado solicitado, preenchendo com cuidado e buscando dar respostas verdadeiras, de modo a contribuir com a validade do estudo.

Obrigada!

a) Sexo: F( ) M( )

b) Idade:

c) Tempo de profissão:

d) Possui curso superior?

e) Possui especialização?

f) Há quanto tempo leciona nesta escola?

g) Disciplina que ministra (p.ex., matemática, educação física, artes):

h) Ano em que leciona (caso dê aula para mais de um dos anos abaixo, selecione-os, mas escolha somente um com base no qual responderá o restante do questionário e indique o ano escolhido):

( ) 10 ano do Ensino Fundamental

( ) 6o ano (ou 5a série) do Ensino Fundamental

( ) 1 10 ano do Ensino Médio

i) Há quanto tempo dá aula aos mesmos alunos do ano indicado em " $h$ "?

j) Quantas aulas dá por semana aos alunos do ano indicado em " $h$ "?

Suponha que, por algum motivo, você tenha que deixar de dar aula para todas as salas para as quais você leciona do ano indicado em " $h$ " e passar a dar aula em outra sala do mesmo ano.

Considerando que alguns dos alunos da(s) sala(s) antiga(s) para as quais você lecionava serão transferidos para sua nova sala, responda:

1 - Se você tivesse que escolher três alunos da(s) sala(s) antiga(s) para continuarem sendo seus alunos na nova sala, quem você escolheria? (Se não se sentir confortável em colocar os nomes, apenas deixe indicado o sexo do aluno escolhido)

Aluno 1:

Aluno 2:

Aluno 3:

1.1 - Explique o principal motivo para a escolha de cada aluno citado na questão "1" (os demais motivos poderão ser indicados na questão "1.2").

Aluno 1:

Aluno 2:

Aluno 3:

1.2 - Se houver, explique os motivos secundários da escolha de cada aluno citado na questão "1". Aluno 1:

Aluno 2:

Aluno 3: 
2 - Se você tivesse que escolher três alunos da(s) sala(s) antiga(s) para não serem transferidos para a nova sala, de modo que você não continuaria dando aula para esses três, quem você escolheria (se não se sentir confortável em colocar os nomes, apenas deixe indicado o sexo do aluno escolhido)?

Aluno 1:

Aluno 2:

Aluno 3:

2.1 - Explique o principal motivo para a escolha de cada aluno citado na questão " 2 " (os demais motivos poderão ser indicados na questão "2.2").

Aluno 1:

Aluno 2:

Aluno 3:

2.2 - Se houver, explique os motivos secundários da escolha de cada aluno citado na questão "2". Aluno 1:

Aluno 2

Aluno 3: 
APÊNDICE C - Termo de Consentimento - versão professor

\section{Termo de consentimento livre e esclarecido*}

Natureza da pesquisa. Você está sendo convidado(a) a participar desta pesquisa, que tem como objetivo investigar como as características dos alunos influenciam no relacionamento deles com seus professores. Participantes da pesquisa. Serão professores do 10 ano do Ensino Fundamental I, 60 ano do Ensino Fundamental II e 10 ano do Ensino Médio.

Envolvimento na pesquisa. A sua participação consistirá em preencher um questionário no qual será solicitado(a) a dados pessoais (sexo, idade, tempo total de profissão, tempo que leciona na escola participante, matéria que leciona etc.). Em seguida, será solicitado que explique os motivos pelos quais escolheria, em uma situação hipotética, alunos indicados para os quais continuaria lecionando, e os motivos pelos quais escolheria alunos indicados para os quais não continuariam lecionando. Você poderá participar do estudo somente mediante a assinatura do presente Termo de Consentimento, tendo a liberdade de interromper sua participação a qualquer momento.

Riscos. A participação nesta pesquisa não traz complicações ou riscos de qualquer espécie.

Confidencialidade. Todas as informações colhidas são confidenciais e não exporão os participantes.

Benefícios. A participação permitirá a realização de discussões teórico-empíricas que possibilitarão o delineamento de estratégias mais precisas e eficazes de intervenção no que concerne ao relacionamento professor-aluno.

Pagamento. Não haverá nenhum tipo de despesa com a participação nem qualquer tipo de pagamento.

Tendo em vista os itens acima apresentados, eu,

, de forma livre e esclarecida, manifesto interesse em participar

da pesquisa.

de de 2013

Assinatura do participante

Orientadora: Profa. Dra. Márcia Helena da Silva Melo Bertolla

E-mail:mmelo@usp.br

Pesquisadora: Sarah Izbicki

E-mail: sarahizbicki@yahoo.com.br

Endereço: Av. Prof. Mello Moraes 1721 - Bloco F

CEP 05508-030 / Cidade Universitária - São Paulo - SP

Telefone (11) 3091-1947

* A pesquisadora se colocará à disposição para sanar quaisquer dúvidas acerca do estudo.

* O presente Termo de Consentimento foi elaborado em 2 (duas) vias, das quais uma ficará com o

professor participante e, outra, com a pesquisadora. 
APÊNDICE D - Termo de Consentimento - versão escola

\section{Termo de consentimento livre e esclarecido*}

Natureza da pesquisa. A Escola é convidada a participar desta pesquisa, que tem como objetivo investigar como as características dos alunos influenciam no relacionamento deles com seus professores.

Participantes da pesquisa. Serão professores do 1 을 ano do Ensino Fundamental I, 6o ano do Ensino Fundamental II e 10 ano do Ensino Médio.

Envolvimento na pesquisa. O professor preencherá um questionário no qual será solicitado a informar dados pessoais (sexo, idade, tempo total de profissão, tempo que leciona na escola participante, matéria que leciona etc.). Em seguida, será solicitado que explique os motivos pelos quais escolheria, em uma situação hipotética, alunos indicados para os quais continuaria lecionando, e os motivos pelos quais escolheria alunos indicados para os quais não continuariam lecionando. O professor participará do estudo somente mediante assinatura do Termo de Consentimento, tendo a liberdade de interromper a participação a qualquer momento.

Riscos. A adesão à pesquisa acarretará riscos mínimos aos participantes. O professor poderá se sentir desconfortável ao manifestar sua opinião sobre seus alunos. Caso isso ocorra, a pesquisadora se prontificará a atender individualmente e em caráter sigiloso a demanda de cada professor.

Confidencialidade. Todas as informações colhidas são confidenciais e não exporão os participantes.

Benefícios. A participação permitirá a realização de discussões teórico-empíricas que possibilitarão o delineamento de estratégias mais precisas e eficazes de intervenção, no que concerne ao relacionamento professor-aluno.

Pagamento. Não haverá nenhum tipo de despesa com a participação nem qualquer tipo de pagamento.

Tendo em vista os itens acima apresentados, eu, de forma livre e esclarecida, manifesto interesse em que os professores da Escola participem da pesquisa.

Nome do responsável pela escola

Assinatura do responsável pela escola

Função e data

Orientadora: Profa. Dra. Márcia Helena da Silva Melo Bertolla

E-mail: mmelo@usp.br

Pesquisadora: Sarah Izbicki

E-mail: sarahizbicki@yahoo.com.br

Endereço: Av. Prof. Mello Moraes 1721 - Bloco F

CEP 05508-030 / Cidade Universitária - São Paulo - SP

Telefone (11) 3091-1947

* A pesquisadora se colocará à disposição para sanar quaisquer dúvidas acerca do estudo.

* O presente Termo de Consentimento foi elaborado em 2 (duas) vias, das quais uma ficará com a instituição participante e, outra, com a pesquisadora. 


\section{APÊNDICE E - Listas das respostas dos professores fornecidas aos juízes para verificação das categorias}

\section{Aceitação}

1. A aluna já apresenta melhoras na conquista do 62. Esforçado conhecimento, gostaria de acompanhá-la
3. Adora ler
63. Espírito de liderança bom
4. Afinidade
64. Estudiosa
5. Alfabetizada
65. Excelente comportamento/cumpre regras e combinados

6. Amigo/companheiro

66. Excelente em aproveitamento

7. Aparente dificuldade

67. Excelente em comportamento

8. Aplicação nos estudos

68. Gentil

9. Aplicado

69. Gosta de aprender coisas novas

10. Aprender a conviver e interagir

70. Habilidade

11. Aprendizagem

71. Habilidade e competencia - sensibilidade

12. Assídua

72. Identificação com o perfil do aluno

13. Assíduo

73. Inteligência

14. Auxilia e ajuda os que tem dificuldade

74. Interatividade

15. Auxilia o colega nas tarefas

75. Interesse

16. Bastante sociável

76. Interesse em aprender

17. Bom comportamento

77. Interesse na disciplina

18. Bom envolvimento nas aulas

78. Interesse nos estudos

19. Bom relacionamento

79. Interesse pela disciplina

20. Caprichosa

80. Interesse pelas atividades

21. Carência, dificuldade de aprendizagem

81. Interesse pelo estudo (conhecimento)

22. Carisma

82. Liderança

23. Colaborativa com os demais

83. Liderança positiva

24. Com aspectos críticos de opinião

84. Muito esforçado

25. Com dificuldades

85. Necessita de atenção pois mimada

26. Competente e esforçado

86. Necessita muita atenção por ter tido trauma infância

27. Comportamento

87. Organizada - nível fora da média - dedicada talentosa

28. Comprometida com os estudos

88. Ótima atitude em grupo

29. Comprometimento

89. Ótimo relacionamento com os outros 
30. Comprometimento com o processo de ensinoaprendizagem

31. Comprometimento com os estudos

32. Compromisso em aprender e estudar

33. Curiosidade

34. Dedicação

35. Dedicada

36. Dedicada aos estudos, comprometida com a atividades

37. Dedicado aos estudos

38. Dedicado, que se doa mais do que o solicitado

39. Demonstra empenho em aprender

40. Desafiador, questionador, sempre adiante

41. Desafiadora, se mostra pesquisadora

42. Desenvoltura

43. Desinteressado mas que assimila conteúdo rapidamente

44. Determinada em aprender

45. Dificuldade

46. Dificuldade de aprendizagem

47. Dificuldade de aprendizagem por déficit de atenção

48. Dificuldade motora (inclusão)

49. Disciplina

50. Disciplinada

51. Disciplinados, organizados e pontuas

52. Disponibilidade em ajudar os outros

53. É muito inteligente

54. Educado

55. Em outra turma teria um desempenho melhor
90. Pais presentes; esta aluna tem já seu ideal de vida

91. Participação

92. Participação nas aulas

93. Participação/interesse em estudar

94. Participante

95. Participativo

96. Pela dedicação aos estudos

97. Pensamento crítico e boa capacidade argumentativa

98. Possuem senso crítico tanto no âmbito escolar quanto no dia a dia

99. Possui conhecimento básico para o estudo da física, tendo facilidade de aprender e compreender os assuntos abordados em sala, como também tentam encontrar diferentes soluções às questões sucessivamente apresentadas em sala.

100.Prestativa

101.Questionador e participativo

102.Questionadora e organizada

103.Questionadora que está sempre insatisfeita 104.Questionamento

105. Realizam as atividades em sala e fora dela

106. Relacionamento

107. Respeito aos professores

108. Respeito pelo professor e pelos colegas e pela escola

109.Responsável

110.Responsável e organizada

111.Responsável, participativo, atende o que é pedido

112. Retraído, com dificuldades

113.Se empenha nas atividades, responsável e estudiosa

114.Sempre aberta às discussões e pesquisa

115.Sinestésico e polivalente 
56. Empatia

57. Empenhado

58. Empenho

59. Envolve todos os outros alunos

60. Envolvida

61. Envolvido com as atividades propostas

1. faltante"

2. A postura pedagógica que respeita o saber elaborado pelo aluno só pode ser possível quando o professor é capacitado para lidar com essa situação. O aluno precisa de cuidados especiais (Inteligencia e S. Down)

3. Acredita que por ser bonita não precisa estudar
4. Agressivo
5. Ansioso
6. Apatia (nada o motiva)
7. Apática
8. Aprendizagem
9. Apresenta certa indisposição com todos os alunos

10. Arrogância

11. Arrogante

12. Arruma muita confusão

13. Atrapalha os colegas

14. Causa diversas confusões em sala

15. Com comportamento apático, não responde a comandos

16. Comparece apenas para brincar

17. Comportamento

18. Comportamento e atitudes inadequados na escola

19. Conversadora

20. Debochado, mal criado
116.Sociável

117.Supermotivado

118.Tem compromisso, responsabilidade e é dedicado aos estudos

119.Tem muita dificuldade, mas é esforçada

120.Tem muito potencial

121.Vontade de aprender

122.Vontade de aprender, apesar das dificuldades

\section{Rejeição}

60. Faltosa

61. Faz questão de não progredir

62. Frequência irregular

63. Imaturidade

64. Improdutivo

65. Indisciplina

66. Indisciplinado

67. Indisciplinado sem limites

68. Indisciplinado, e que acredita que o mundo está para servi-lo

69. Irresponsável com as aterfas

70. Líder negativo

71. Líder negativo, coloca os colegas contra os outros

72. Líder ruim

73. Mal criado

74. Mal educado

75. Mimado

76. Muito brincalhão e atrapalha a aula

77. Não aceita ser corrigida

78. Não alfabetizado

79. Não comprometido com o ensino 
21. Demora para realizar as atividades

22. Desatento

23. Descomprometimento com as aulas

24. Descompromissado

25. Desfocado

26. Desinteressado

27. Desinteressado e não alfabetizado

28. Desinteressado, sem compromisso com os deveres escolares

29. Desinteresse

30. Desinteresse com o conteúdo

31. Desinteresse, descompromisso

32. Desmotivado

33. Desrespeitador com colegas

34. Desrespeito aos colegas

35. Desrespeitoso

36. Desrespeitoso com todos

37. Desrespeitoso e indisciplinado

38. Dificuldade de aceitar regras

39. Dificuldade de concentração

40. Dispersa

41. Disperso

42. Disperso com os outros assuntos

43. Dissimulada

44. Distraída e tem preguiça

45. É a criança que mais preenche o dia, é bastante comunicativo, porém desorganizado. Necessita de orientação constantemente. Já foi solicitado aos pais uma avaliação psicopedagógica

46. É displicente com a escola e o estudo

47. Esconde-se atrás de sua deficiência
80. Não participa das aulas

81. Não participa das aulas, não há comprometimento com as atividades

82. Não possui vontade de aprender como também não realiza atividades propostas

83. Não precisa de uma atenção tão grande quanto os demais

84. Não produz

85. Não produz, é descomprometido

86. Não quer estudar

87. Não quer parar na sala - só andar

88. Não realiza as atividades

89. Não realiza/aceita as propostas oferecidas

90. Não respeita/compreende a "rotina" escolar

91. Não tem a menor ideia da matéria que lhe é cobrado

92. Não tem compromisso com os estudos

93. Não tem higiene pessoal

94. Não tem propósito de vida ainda

95. Negligência com estudo

96. Participa pouco das aulas, sem responsabilidade com o conteúdo

97. Pouco interessado na aula

98. Pouco participativo

99. Pouco participativo, desinteressado

100.Precisa de trabalho diferenciado, envolvendo outras especialidades também e claro principalmente da família

101.Preguiça

102.Quantitativo (objetivo é a nota)

103. Relacionamento

104. Respaldo da conduta

105.Respondão

106. Responsabilidade familiar 
48. Excesso de faltas

49. Falta de comprometimento

50. Falta de compromisso

51. Falta de compromisso e desinteresse

52. Falta de consideração pelos colegas

53. Falta de dedicação

54. Falta de educação e respeito

55. Falta de interesse

56. Falta de interesse em estudar

57. Falta de participação

58. Falta de pré-requisitos (leitura/escrita)

59. Falta de valores para com os estudos
107.Se envolve facilmente de forma negativa com os outros

108.Sem autonomia

109.Sem compromisso

110.Sem foco nos estudos

111.Sem interesse - não quer estudar

112.Sem limites

113.Sem vontade de aprender

114.Só estuda (ou vem a escola) pelo bolsa família

115.Tem muita dificuldades, mas não se esforça para aprender

116.Tem ótimo relacionamento com a sala. Líder bom. Aluno que está preparado para desenvolver trabalhos em grupos diversificados, pois tem boas influências familiares

117.Usuário de drogas

118. Violento 
APÊNDICE F - Tabela fornecida aos juízes para verificação das categorias

\begin{tabular}{|c|c|c|c|}
\hline \multicolumn{4}{|c|}{ Categorias de Aceitação } \\
\hline Nome & Sigla & Definição & Exemplos \\
\hline Presença de dificuldades & PDi & $\begin{array}{l}\text { o aluno apresenta ou apresentava dificuldades, } \\
\text { podendo ser explicitado que estas fazem com } \\
\text { que o professor queira prestar auxílio a ele e/ou } \\
\text { identifique a necessidade de fazer isso }\end{array}$ & \\
\hline Engajamento nos estudos & $\mathrm{EE}$ & $\begin{array}{l}\text { o aluno possui características ou se engaja em } \\
\text { comportamentos diretamente favoráveis a sua } \\
\text { aprendizagem }\end{array}$ & \\
\hline Disciplina & $\mathrm{D}$ & $\begin{array}{l}\text { o aluno possui características ou se engaja em } \\
\text { comportamentos que se adequam às regras } \\
\text { implícitas ou explícitas da sala ou escola - } \\
\text { voltados a outros alunos, aos colegas e/ou ao } \\
\text { professor -, facilitando a organização do } \\
\text { ambiente e o andamento da aula }\end{array}$ & \\
\hline Outros & $\mathrm{aO}$ & $\begin{array}{l}\text { respostas que, pela falta de especificações, não } \\
\text { puderam ser incorporadas em nenhuma das } \\
\text { categorias ou poderiam ser inseridas em mais de } \\
\text { uma delas }\end{array}$ & \\
\hline \multicolumn{4}{|c|}{ Categorias de Rejeição } \\
\hline Nome & Sigla & Definição & Exemplos \\
\hline Presença de déficits & PDe & $\begin{array}{l}\text { o aluno apresenta déficits de pré-requisitos para } \\
\text { o aprendizado, podendo demandar muito tempo } \\
\text { ou atenção do professor ou tornar sua atuação } \\
\text { insuficiente, fazendo com que o professor queira } \\
\text { ou ache necessária a atuação de outros } \\
\text { profissionais, sejam professores com a mesma } \\
\text { função que o participante ou profissionais de } \\
\text { outras áreas. }\end{array}$ & \\
\hline $\begin{array}{l}\text { Falta de engajamento nos } \\
\text { estudos }\end{array}$ & FEE & $\begin{array}{l}\text { o aluno possui características ou se engaja em } \\
\text { comportamentos desfavoráveis à aprendizagem, } \\
\text { por falta de interesse, pela ausência de } \\
\text { participação e/ou por ter sua atenção dirigida a } \\
\text { eventos não relacionados aos objetivos } \\
\text { acadêmicos das atividades propostas pelo } \\
\text { professor }\end{array}$ & \\
\hline Indisciplina & । & $\begin{array}{l}\text { o aluno possui características ou se engaja em } \\
\text { comportamentos incompatíveis com as regras } \\
\text { implícitas ou explícitas da sala ou escola - } \\
\text { voltados a outras pessoas ou a objetos -, } \\
\text { dificultando a organização do ambiente e o } \\
\text { andamento da aula }\end{array}$ & \\
\hline Outros & $\mathrm{rO}$ & $\begin{array}{l}\text { respostas que, pela falta de especificações ou } \\
\text { por serem discrepantes das outras categorias, } \\
\text { não puderam ser incorporadas em nenhuma das } \\
\text { categorias ou poderiam ser inseridas em mais de } \\
\text { uma delas }\end{array}$ & \\
\hline
\end{tabular}


APÊNDICE G - Tabelas referentes aos dados brutos das análises realizadas nas seções 5.2.2. a 5.2.4.

Tabela 4.

Número de citações de cada categoria de aceitação, nos três anos escolares

\begin{tabular}{cccc}
\hline Categoria & $\begin{array}{c}\text { 10 ano Ensino } \\
\text { Fundamental }\end{array}$ & $\begin{array}{c}\text { 6o ano Ensino } \\
\text { Fundamental }\end{array}$ & $\begin{array}{c}\text { 10 ano Ensino } \\
\text { Médio }\end{array}$ \\
\hline$D$ & 12 & 3 & 1 \\
\hline$E E$ & 20 & 33 & 74 \\
\hline$E E+D$ & 6 & 6 & 0 \\
\hline$E E+O$ & 4 & 3 & 3 \\
\hline$O$ & 12 & 0 & 5 \\
\hline Pdi & 7 & 2 & 1 \\
\hline Pdi+D & 1 & 0 & 0 \\
\hline Pdi+EE & 0 & 1 & 0 \\
\hline
\end{tabular}

Tabela 5.

Número de citações de cada categoria de rejeição, nos três anos escolares

\begin{tabular}{cccc}
\hline Categoria & $\begin{array}{c}\text { 10 ano Ensino } \\
\text { Fundamental }\end{array}$ & $\begin{array}{c}\text { 6o ano Ensino } \\
\text { Fundamental }\end{array}$ & $\begin{array}{c}\text { 10 ano Ensino } \\
\text { Médio }\end{array}$ \\
\hline FEE & 11 & 19 & 43 \\
\hline FEE+1 & 3 & 3 & 3 \\
\hline FEE+O & 1 & 0 & 3 \\
\hline FEE+Pde & 0 & 0 & 1 \\
\hline FEE+1+O & 0 & 3 & 1 \\
\hline 1 & 26 & 14 & 16 \\
\hline I+FEE+Pde & 1 & 3 & 0 \\
\hline$O$ & 9 & 3 & 0 \\
\hline O+I & 2 & 0 & 5 \\
\hline Pde & 1 & 2 &
\end{tabular}

Tabela 6.

Número de indicações de meninas e meninos aceitos pelos professores de cada sexo, conforme o sexo do aluno indicado

\begin{tabular}{lccc}
\cline { 3 - 4 } & & & \\
& & & \\
Sluno & Aluna \\
\hline \multirow{2}{*}{ Sexo do professor } & Masculino & 25 & 63 \\
\cline { 2 - 4 } & Feminino & 32 & 74 \\
\hline
\end{tabular}


Tabela 7.

Número de indicações de meninas e meninos rejeitados pelos professores de cada sexo, conforme o sexo do aluno indicado

\begin{tabular}{cccc}
\cline { 2 - 3 } & & Aluno & Aluna \\
\hline \multirow{2}{*}{ Sexo do professor } & Masculino & 44 & 13 \\
\cline { 2 - 4 } & Feminino & 102 & 25
\end{tabular}

Tabela 8.

Número de indicações de meninas e meninos aceitos pelos professores que lecionam em cada área

\begin{tabular}{cccc}
\cline { 2 - 3 } & & Aluno & Aluna \\
\hline \multirow{3}{*}{ Área em que leciona } & Biológicas & 7 & 8 \\
\cline { 2 - 4 } & Educação Física/artes & 20 & 25 \\
\cline { 2 - 4 } & Exatas & 14 & 10 \\
\cline { 2 - 4 } & Humanas & 15 & 24 \\
\cline { 2 - 4 } & Línguas & 11 & 16 \\
\cline { 2 - 4 } & Línguas e Exatas & 2 & 1 \\
\cline { 2 - 4 } & Outros & 8 & 4 \\
\cline { 2 - 4 } & Polivalente & 11 & 18 \\
\hline
\end{tabular}

Tabela 9.

Número de indicações de meninas e meninos rejeitados pelos professores que lecionam em cada área

\begin{tabular}{|c|c|c|c|}
\hline & & Aluno & Aluna \\
\hline \multirow{8}{*}{ Área em que leciona } & Biológicas & 11 & 4 \\
\hline & Educação Física/artes & 36 & 8 \\
\hline & Exatas & 16 & 8 \\
\hline & Humanas & 32 & 7 \\
\hline & Línguas & 20 & 6 \\
\hline & Línguas e Exatas & 3 & 0 \\
\hline & Outros & 8 & 1 \\
\hline & Polivalente & 20 & 4 \\
\hline
\end{tabular}


Tabela 10.

Número de citações de cada categoria de aceitação pelos professores de cada disciplina

Categoria Biológicas $\begin{gathered}\text { Educação } \\ \text { Física/artes }\end{gathered}$ Exatas Humanas Línguas $\begin{gathered}\text { Línguas e } \\ \text { Exatas }\end{gathered}$ Outros Polivalente

\begin{tabular}{ccccccccc}
\hline $\mathrm{D}$ & 0 & 8 & 1 & 2 & 1 & 0 & 2 & 2 \\
\hline $\mathrm{EE}$ & 12 & 31 & 16 & 34 & 17 & 0 & 3 & 14 \\
\hline $\mathrm{EE}+\mathrm{D}$ & 0 & 4 & 0 & 0 & 3 & 3 & 2 & 0 \\
\hline $\mathrm{EE}+\mathrm{O}$ & 0 & 0 & 3 & 0 & 3 & 0 & 1 & 3 \\
\hline $\mathrm{O}$ & 2 & 0 & 3 & 2 & 3 & 0 & 0 & 7 \\
\hline $\mathrm{Pdi}$ & 1 & 1 & 1 & 1 & 0 & 0 & 3 & 3 \\
\hline Pdi+D & 0 & 1 & 0 & 0 & 0 & 0 & 0 & 0 \\
\hline Pdi+EE & 0 & 0 & 0 & 0 & 0 & 0 & 1 & 0 \\
\hline
\end{tabular}

Tabela 11.

Número de citações de cada categoria de rejeição pelos professores de cada disciplina

\begin{tabular}{ccccccccc}
\hline Categoria & Biológicas & $\begin{array}{c}\text { Educação } \\
\text { Física/ artes }\end{array}$ & Exatas & Humanas & Línguas & $\begin{array}{c}\text { Línguas e } \\
\text { Exatas }\end{array}$ & Outros & Polivalente \\
\hline FEE & 9 & 20 & 4 & 21 & 10 & 0 & 1 & 8 \\
\hline FEE+l & 2 & 1 & 0 & 4 & 0 & 1 & 1 & 0 \\
\hline FEE+O & 0 & 1 & 0 & 0 & 2 & 1 & 0 & 0 \\
\hline FEE+Pde & 0 & 0 & 0 & 1 & 0 & 0 & 0 & 0 \\
\hline FEE+1+O & 0 & 0 & 3 & 0 & 1 & 0 & 0 & 0 \\
\hline 1 & 2 & 16 & 10 & 11 & 4 & 0 & 5 & 8 \\
\hline I+FEE+Pde & 0 & 1 & 0 & 0 & 3 & 0 & 0 & 0 \\
\hline$O$ & 0 & 5 & 4 & 1 & 7 & 1 & 0 & 5 \\
\hline O+l & 0 & 0 & 0 & 0 & 0 & 0 & 0 & 2 \\
\hline Pde & 2 & 0 & 3 & 0 & 0 & 0 & 2 & 1 \\
\hline
\end{tabular}

Tabela 12.

Número de citações de cada categoria de aceitação, conforme o sexo do aluno indicado

\begin{tabular}{ccc}
\hline Categoria & Alunos & Alunas \\
\hline$D$ & 8 & 8 \\
\hline$E E$ & 54 & 73 \\
\hline$E E+D$ & 6 & 6 \\
\hline$E E+O$ & 4 & 6 \\
\hline$O$ & 8 & 9 \\
\hline Pdi & 7 & 3 \\
\hline Pdi+D & 0 & 1 \\
\hline Pdi+EE & 1 & 0 \\
\hline
\end{tabular}


Tabela 13.

Número de citações de cada categoria de rejeição, conforme o sexo do aluno indicado

\begin{tabular}{ccc}
\hline Categoria & Alunos & Alunas \\
\hline FEE & 55 & 18 \\
\hline FEE +1 & 8 & 1 \\
\hline FEE $+O$ & 4 & 0 \\
\hline FEE + Pde & 1 & 0 \\
\hline FEE $+1+O$ & 3 & 1 \\
\hline 1 & 49 & 7 \\
\hline $1+F E E+P d e$ & 3 & 1 \\
\hline$O$ & 13 & 9 \\
\hline$O+1$ & 2 & 0 \\
\hline$P d e$ & 7 & 1
\end{tabular}

Tabela 14.

Número de citações de cada categoria de aceitação pelos professores de cada sexo

\begin{tabular}{ccc}
\hline Categoria & Masculino & Feminino \\
\hline$D$ & 6 & 10 \\
\hline$E E$ & 45 & 82 \\
\hline$E E+D$ & 1 & 11 \\
\hline$E E+O$ & 0 & 10 \\
\hline$O$ & 3 & 14 \\
\hline$P d i$ & 1 & 9 \\
\hline$P d i+D$ & 0 & 1 \\
\hline Pdi+EE & 1 & 0 \\
\hline
\end{tabular}

Tabela 15.

Número de citações de cada categoria de rejeição pelos professores de cada sexo

\begin{tabular}{ccc}
\hline Categoria & Masculino & Feminino \\
\hline FEE & 27 & 46 \\
\hline FEE +1 & 7 & 2 \\
\hline FEE $+O$ & 1 & 3 \\
\hline FEE + Pde & 1 & 0 \\
\hline FEE $+1+O$ & 0 & 4 \\
\hline I & 15 & 41 \\
\hline I+FEE+Pde & 0 & 4 \\
\hline$O$ & 3 & 20 \\
\hline O+I & 0 & 2 \\
\hline Pde & 2 & 6
\end{tabular}


APÊNDICE G - Respostas de aceitação e rejeição que constituem as categorias "Outros", em função do ano escolar, do sexo do aluno, do sexo do professor e da área na qual ele leciona

\begin{tabular}{|l|l|}
\hline \multicolumn{2}{|c|}{ Aceitação } \\
\hline 1o ano EF & $\begin{array}{l}\text { Aprendizagem (3)7 ; Relacionamento (2); Empatia (2); Aprender a conviver e interagir; } \\
\text { Carisma; Cinestésico e polivalente; Disciplinado (4); Afinidade; Desenvoltura }\end{array}$ \\
\hline 6o ano EF & Disciplina (3) \\
\hline 1o ano EM & $\begin{array}{l}\text { Confiança; Disponibilidade; Em outra turma teria desempenho melhor; Disciplinado, } \\
\text { organizado e pontual (3); Era dispersa. Passou a compreender melhor; Identificação com o } \\
\text { perfil do aluno }\end{array}$ \\
\hline \multicolumn{1}{|c|}{ Rejeição } \\
\hline & $\begin{array}{l}\text { Aprendizagem (2); Relacionamento (2); Esconde-se atrás de sua deficiência; Ansioso; } \\
\text { Mimado; Aluno que é muito bem disciplinado e que perante a situações problemas } \\
\text { consegue se sair muito bem. Aluno que não precisa de uma atenção tão grande quanto os } \\
\text { demais; aluno que tem ótimo relacionamento com a sala. Líder bom. Aluno que está } \\
\text { preparado para desenvolver trabalhos em grupos diversificados, pois tem boas influências } \\
\text { familiares; Comportamento apático, não responde a comandos; "faltante"; Respaldo da } \\
\text { conduta }\end{array}$ \\
\hline 6o ano EF & Faltas (5); Responsabilidade familiar \\
\hline 1o ano EM & $\begin{array}{l}\text { Quantitativo (objetivo é a nota); Sem autonomia; faltosa (3); Não respeita/compreende } \\
\text { rotina escolar; Não tem propósito de vida ainda; Usuário de drogas }\end{array}$ \\
\hline
\end{tabular}

\begin{tabular}{|l|l|}
\hline \multicolumn{2}{|c|}{ Aceitação } \\
\hline Aluno & $\begin{array}{l}\text { Aprendizagem (2); Carisma; Cinestésico e polivalente; Disciplinado (4); Confiança; } \\
\text { Disponibilidade; Disciplinado, organizado e pontual; identificação com o perfil do aluno }\end{array}$ \\
\hline Aluna & $\begin{array}{l}\text { Relacionamento (3); Empatia (2); Aprender a conviver e interagir; Disciplinado (3); } \\
\text { Afinidade; Desenvoltura; Em outra turma teria desempenho melhor; Disciplinado, } \\
\text { organizado e pontual (2); Era dispersa. Passou a compreender melhor }\end{array}$ \\
\hline \multicolumn{1}{|c|}{ Rejeição } \\
\hline Aluno & $\begin{array}{l}\text { Aprendizagem (2); mimado; ansioso; Aluno que é muito bem disciplinado e que perante a } \\
\text { situações problemas consegue se sair muito bem. Aluno que não precisa de uma atenção } \\
\text { tão grande quanto os demais; aluno que tem ótimo relacionamento com a sala. Líder bom. } \\
\text { Aluno que está preparado para desenvolver trabalhos em grupos diversificados, pois tem } \\
\text { boas influências familiares; aluno com comportamento apático, não responde a comandos; } \\
\text { respaldo da conduta; faltas (6); responsabilidade familiar; não respeita/compreende a } \\
\text { "rotina" escolar; não tem propósito de vida ainda; usuário de drogas; imaturidade, } \\
\text { comparece apenas para brincar; aluno não tem higiene pessoal; apático }\end{array}$ \\
\hline Aluna & $\begin{array}{l}\text { Relacionamento (2); esconde-se atrás de sua deficiência; faltas; Quantitativo (objetivo é a } \\
\text { nota); Sem autonomia; faltosa; não aceita ser corrigida, aluna faltosa; dissimulado; apático }\end{array}$ \\
\hline
\end{tabular}

\footnotetext{
${ }^{7}$ Os números entre parêntesis correspondem ao número de vezes em que a mesma resposta foi mencionada.
} 


\begin{tabular}{|l|l|}
\hline \multicolumn{2}{|c|}{ Aceitação } \\
\hline Professor & confiança; disponibilidade; identificação com o perfil do aluno \\
\hline Professora & $\begin{array}{l}\text { Aprendizagem (3); Relacionamento (2); Empatia (2); aprender a conviver e interagir; } \\
\text { carisma; cinestésico e polivalente; disciplinado (7); afinidade; desenvoltura; aluna que em } \\
\text { outra turma teria um desempenho melhor; disciplinados, organizados e pontuais; aluna } \\
\text { que era dispersa, passou a compreender melhor }\end{array}$ \\
\hline Professor & \multicolumn{1}{|c|}{ Rejeição } \\
\hline \multicolumn{3}{|l|}{ Quantitativo (objetivo é a nota); Sem autonomia; usuário de drogas; faltoso } \\
\hline & $\begin{array}{l}\text { Aprendizagem (2); Relacionamento (2); esconde-se atrás de sua deficiência; ansioso; } \\
\text { mimado; Aluno que é muito bem disciplinado e que perante a situações problemas } \\
\text { consegue se sair muito bem. Aluno que não precisa de uma atenção tão grande quanto os } \\
\text { demais; aluno que tem ótimo relacionamento com a sala. Líder bom. Aluno que está } \\
\text { preparado para desenvolver trabalhos em grupos diversificados, pois tem boas influências } \\
\text { familiares; aluno com comportamento apático, não responde a comandos; faltas (8); } \\
\text { respaldo da conduta; responsabilidade familiar; o aluno não respeita/compreende a } \\
\text { "rotina" escolar; não tem propósito de vida ainda; só estudo (ou vem a escola) pelo bolsa } \\
\text { família; imaturidade, comparece apenas para brincar; não aceita ser corrigida, aluna } \\
\text { faltosa; aluno não tem higiene pessoal; dissimulada; apática (2) }\end{array}$ \\
\hline
\end{tabular}

\begin{tabular}{|c|c|}
\hline \multicolumn{2}{|r|}{ Aceitação } \\
\hline Grupo A & $\begin{array}{l}\text { disciplinado (6); afinidade; desenvoltura; confiança; disponibilidade; aluna que em outra } \\
\text { turma teria um desempenho melhor; disciplinados, organizados e pontuais (3); aluna que } \\
\text { era dispersa, passou a compreender melhor; identificação com o perfil do aluno; }\end{array}$ \\
\hline Grupo B & (Sem respostas) \\
\hline Outros & disciplinado \\
\hline Polivalente & $\begin{array}{l}\text { Aprendizagem (3); Relacionamento (2); Empatia (2); aprender a conviver e interagir; } \\
\text { carisma; cinestésico e polivalente; }\end{array}$ \\
\hline \multicolumn{2}{|r|}{ Rejeição } \\
\hline Grupo A & $\begin{array}{l}\text { aluno com comportamento apático, não responde a comandos; faltas (5); responsabilidade } \\
\text { familiar; Quantitativo (objetivo é a nota); sem autonomia; o aluno não } \\
\text { respeita/compreende a "rotina" escolar; não tem propósito de vida ainda; só estudo (ou } \\
\text { vem a escola) pelo bolsa família; usuário de drogas; imaturidade, comparece apenas para } \\
\text { brincar; não aceita ser corrigida, aluna faltosa; aluno não tem higiene pessoal; dissimulada; } \\
\text { apatia (2) }\end{array}$ \\
\hline Grupo B & $\begin{array}{l}\text { Aluno que é muito bem disciplinado e que perante a situações problemas consegue se sair } \\
\text { muito bem. Aluno que não precisa de uma atenção tão grande quanto os demais; aluno } \\
\text { que tem ótimo relacionamento com a sala. Líder bom. Aluno que está preparado para } \\
\text { desenvolver trabalhos em grupos diversificados, pois tem boas influências familiares; faltas } \\
\text { (2) }\end{array}$ \\
\hline Outros & (Sem respostas) \\
\hline Polivalente & $\begin{array}{l}\text { Aprendizagem (2); Relacionamento (2); esconde-se atrás de sua deficiência; mimado; } \\
\text { ansioso }\end{array}$ \\
\hline
\end{tabular}

